Supporting Information for

\title{
Room temperature hydrolysis of benzamidines and benzamidiniums in weakly basic water
}

Li-Juan Yu, Duncan A. Cullen, Mahbod Morshedi, Michelle L. Coote, ${ }^{\star}$ and Nicholas G. White*

Research School of Chemistry, The Australian National University, Canberra, ACT, 2600, Australia

Emails:

michelle.coote@anu.edu.au

nicholas.white@anu.edu.au

URLs:

rsc.anu.edu.au/ mcoote/

www.nwhitegroup.com 
Synthesis and characterization

General remarks

Synthesis and characterization of $\mathbf{1} \cdot \mathbf{C l} \cdot \mathrm{H}_{2} \mathrm{O}$

X-ray crystallography

Crystal growth

Additional X-ray pictures

Details of structures and refinements

${ }^{1} \mathrm{H}$ NMR experiments

Spectra of $\mathbf{1} \cdot \mathbf{C l}$

Susceptibility of $\mathbf{1} \cdot \mathbf{C l}$ to oxidation

General procedure for hydrolysis experiments

Hydrolysis of $\mathbf{1} \cdot \mathbf{C l}$ in $\mathrm{pH} 9$ phosphate buffer S12

Hydrolysis of $1 . \mathrm{Cl}$ in $\mathrm{pH} 10$ phosphate buffer

Hydrolysis of $\mathbf{1} \cdot \mathbf{C l}$ in $\mathrm{pH} 11$ phosphate buffer

Hydrolysis of $1 \cdot \mathrm{Cl}$ in $\mathrm{pH} 12$ phosphate buffer

Hydrolysis of $1 \cdot \mathbf{C l}$ in $100 \mathrm{mM} \mathrm{NaOH}_{(\mathrm{aq})}$

S20

Hydrolysis of $\mathbf{1 .} \cdot \mathbf{C l}$ in $1.0 \mathrm{M} \mathrm{NaOH}_{\text {(aq) }}$

Hydrolysis of $1 \cdot \mathbf{C l}$ in $1 \% \mathrm{NH}_{3(\mathrm{aq})}$

S24

Hydrolysis of $\mathbf{2} \cdot \mathbf{C l}_{4}$ in $1 \% \mathrm{NH}_{3(\text { aq) }}$

S26

Hydrolysis of $\mathbf{6} \cdot \mathbf{C l}_{2}$ in $1 \% \mathrm{NH}_{3}$ (aq)

Hydrolysis of $\mathrm{H}$-bonded frameworks

Computational studies

Complete reaction scheme

Kinetic model derivations

Sensitivity Analysis

Gaussian raw data

Optimized solution phase geometries

\section{References}




\section{Synthesis and characterization}

\section{Instrumentation}

NMR spectra were collected on Bruker Avance 400 spectrometers and are referenced to the residual solvent signal. ${ }^{S 1}$ Electrospray ionisation mass spectrometry data were acquired on a Micromass Waters ZMD spectrometer. Thermogravimetric analyses were recorded on a TA Instruments Q500 analyser under flowing nitrogen gas at a heating rate of $5{ }^{\circ} \mathrm{C} /$ minute. PXRD data were recorded at room temperature on a PANalytical Empyrean diffractometer using $\mathrm{Cu}$ $\mathrm{Ka}$ radiation and a PIXcel detector. Details of instrumentation used for X-ray crystallography are given in the X-ray Crystallography section.

\section{Synthesis and characterization of $1 \cdot \mathrm{Cl} \cdot \mathrm{H}_{2} \mathrm{O}$}

Commercially-available $1 \cdot \mathrm{Cl}$ is typically described as "hydrate" or " $\mathrm{xH}_{2} \mathrm{O}$." A commercially-available sample was recrystallised from $1.0 \mathrm{M} \mathrm{HCl}_{(\mathrm{aq})}$. X-ray crystallography reveals that crystals of $\mathbf{1} \cdot \mathbf{C l}$ fresh from the mother liquor are the dihydrate, i.e. $1 \cdot \mathrm{Cl} \cdot 2 \mathrm{H}_{2} \mathrm{O}$ (see X-ray Crystallography section of this document). The bulk crystalline sample was thoroughly air-dried by suction on a glass frit and then left in an open beaker for several days to equilibrate with the atmosphere. This sample was then analysed by thermogravimetric analysis (TGA). As shown in Figure S1, the TGA data are consistent with this equilibrated sample being the monohydrate, i.e. $1 \cdot \mathrm{Cl} \cdot \mathrm{H}_{2} \mathrm{O}$, with a weight loss of just over $10 \%$ observed [expected for monohydrate: $10.3 \%, \mathrm{Mr}_{\text {of }} 1 \cdot \mathrm{Cl} \cdot \mathrm{H}_{2} \mathrm{O}: 174.63 \mathrm{~g} \mathrm{~mol}^{-1}$, $\mathrm{Mr}$ of $\left.1 \cdot \mathrm{Cl}: 156.61 \mathrm{~g} \mathrm{~mol}^{-1}\right]$.

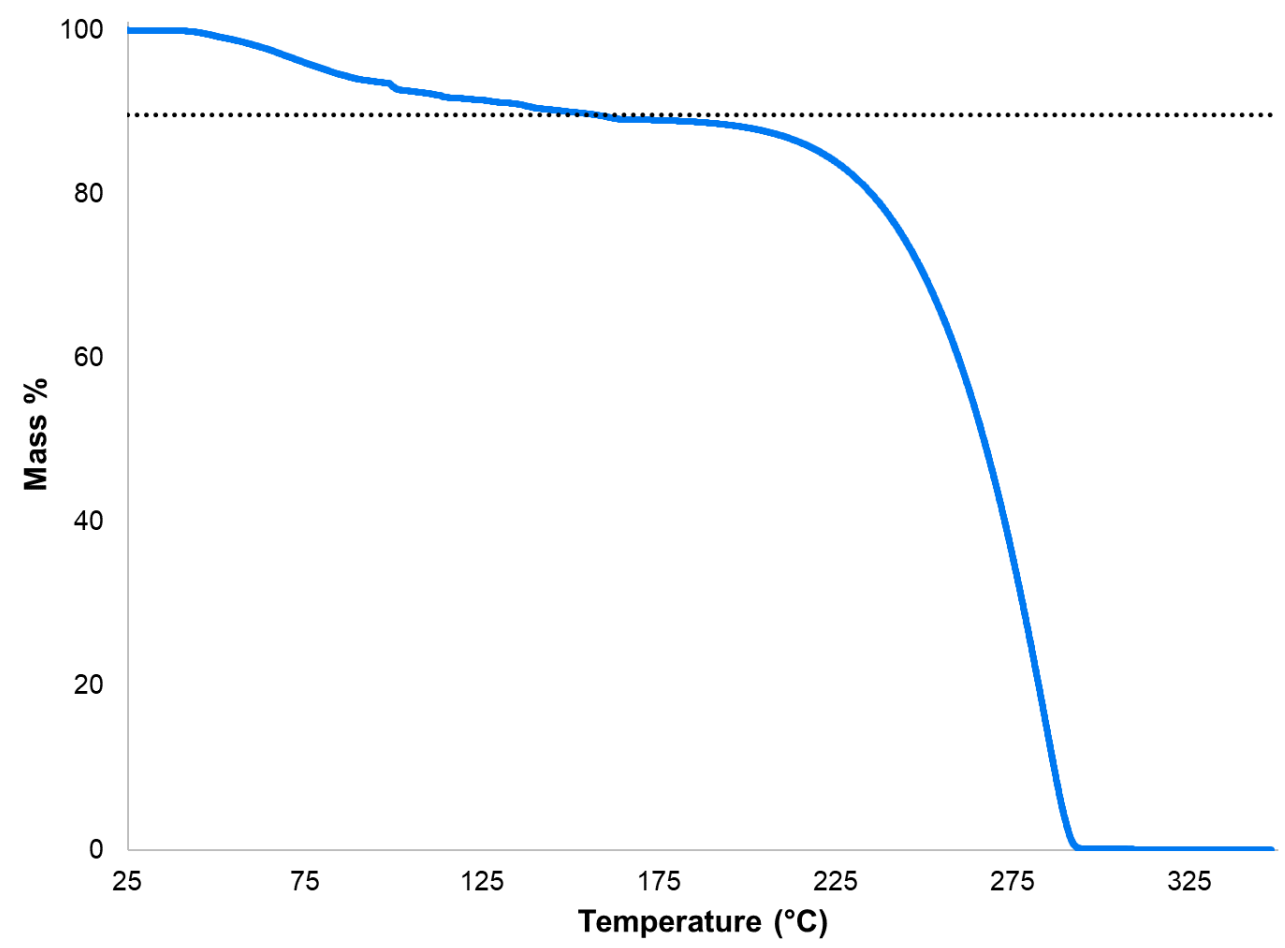

Figure S1. TGA trace of $1 \cdot \mathbf{C l} \cdot \mathrm{H}_{2} \mathrm{O}$ that has been allowed to equilibrate with the atmosphere for several days. The expected weight loss for $1 \cdot \mathrm{Cl} \cdot \mathrm{H}_{2} \mathrm{O}$ is shown as a dotted black line. Recorded under $\mathrm{N}_{2}$ at a heating rate of $5^{\circ} \mathrm{C} /$ minute. 


\section{X-ray crystallography}

\section{Crystal growth}

Crystals of $1 \cdot \mathrm{Cl} \cdot 2 \mathrm{H}_{2} \mathrm{O}$ : Crystals of $1 \cdot \mathrm{Cl} \cdot 2 \mathrm{H}_{2} \mathrm{O}$ were obtained by recrystallizing commercially available benzamidinium chloride hydrate from hot $1.0 \mathrm{M} \mathrm{HCl}_{(\mathrm{aq})}$.

Crystals of 4: Crystals of $\mathbf{4}$ were obtained over several days by adding $\mathrm{NH}_{3 \text { (aq) }}$ to a mixture of $\mathbf{2} \cdot \mathrm{Cl}_{\mathbf{4}}$ and bromoterephthalic acid in water. As discussed in the main text, we typically prepare hydrogen bonded amidinium $\cdots$ carboxylate frameworks by mixing tetrabutylammonium salts of carboxylates with $\mathbf{2} \cdot \mathbf{C l}_{4}$ but were investigating whether mixing the carboxylic acid with an aqueous base would be an easier way to synthesize frameworks. Crystals were also isolated from a mixture of $\mathrm{NH}_{3(\mathrm{aq})}$, $2 \cdot \mathrm{Cl}_{4}$ and anthracenedicarboxylic acid, and were shown by X-ray crystallography to be 4 .

Crystals of 5: Crystals of 5 were obtained over several weeks from a solution of $3 \cdot \mathbf{C l}_{4}$ in dilute $\mathrm{NaHCO}_{3(\mathrm{aq}) \text {. }}$

\section{Additional X-ray pictures}

Hydrogen bonding in $1 \cdot \mathrm{Cl} \cdot 2 \mathrm{H}_{2} \mathrm{O}$ : The structure of $1 \cdot \mathbf{C l} \cdot 2 \mathrm{H}_{2} \mathrm{O}$ is shown in Figure $\mathrm{S} 2$. The benzamidinium cation forms short hydrogen bonds to one water molecule and one chloride anion, with the water molecule giving a hydrogen bond to the two chloride anions, such that $\mathbf{1}^{+}$cations are assembled into hydrogen bonded dimers. The benzamidinium hydrogen bonds are relatively short $\left[\mathrm{H} \cdots \mathrm{O}=2.11 \AA, \mathrm{H}^{\cdots} \mathrm{Cl}^{-}=2.39 \AA ; \mathrm{N} \cdots \mathrm{O}=2.949(1) \AA, \mathrm{N} \cdots \mathrm{Cl}=3.239(1) \AA\right]$.

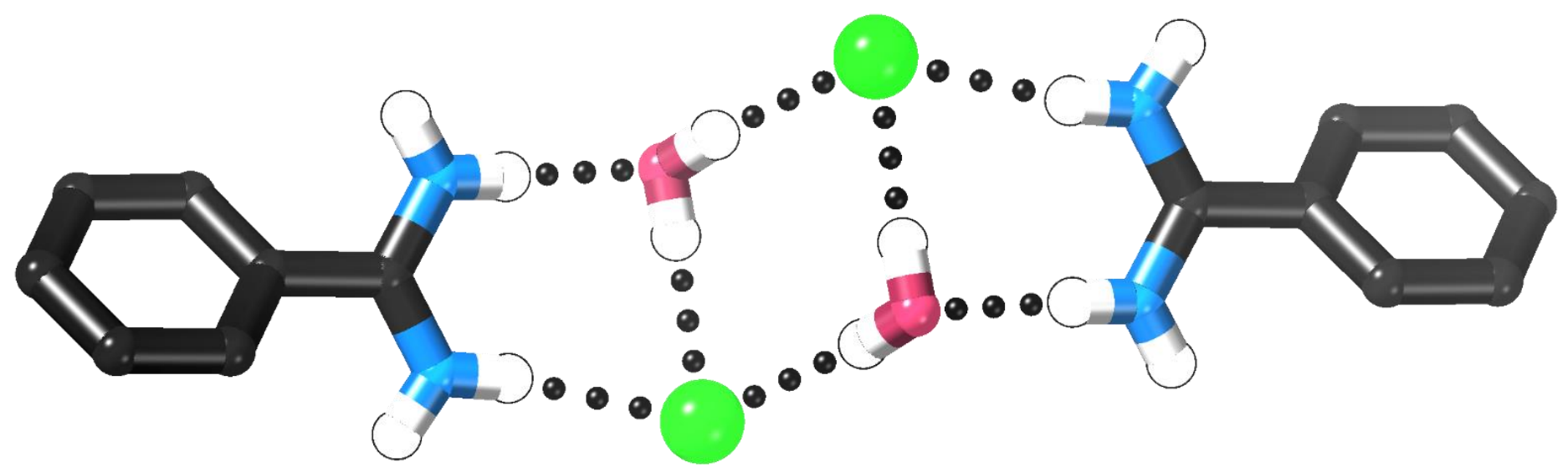

Figure S2. Diagram showing the $\mathrm{H}$-bonded dimers formed by $1 \cdot \mathbf{C l} \cdot 2 \mathrm{H}_{2} \mathrm{O}$ (one water molecule per $\mathbf{1}^{+}$molecule is not shown). 
Structure of 5: The structure of 5 is isostructural with 4 . The unit cell volume is slightly larger (Table S1) due to the increased length of the $\mathrm{Si}-\mathrm{C}$ bond $v s$. the $\mathrm{C}-\mathrm{C}$ bond in $\mathbf{4}$. Hydrogen bond distances are slightly different, with $\mathbf{5}$ containing slightly longer amide $\cdots$ amide hydrogen bonds $[\mathrm{H} \cdots \mathrm{O}=1.95 \AA$ for $4,2.00 \AA$ for 5 ; $\mathrm{N} \cdots \mathrm{O}=2.853(2) \AA$ in $4,2.865(2)$ in 5 ]. A packing diagram and picture of the double-helical $\mathrm{H}$-bonding arrangement are provided in Figures S3 and S4.

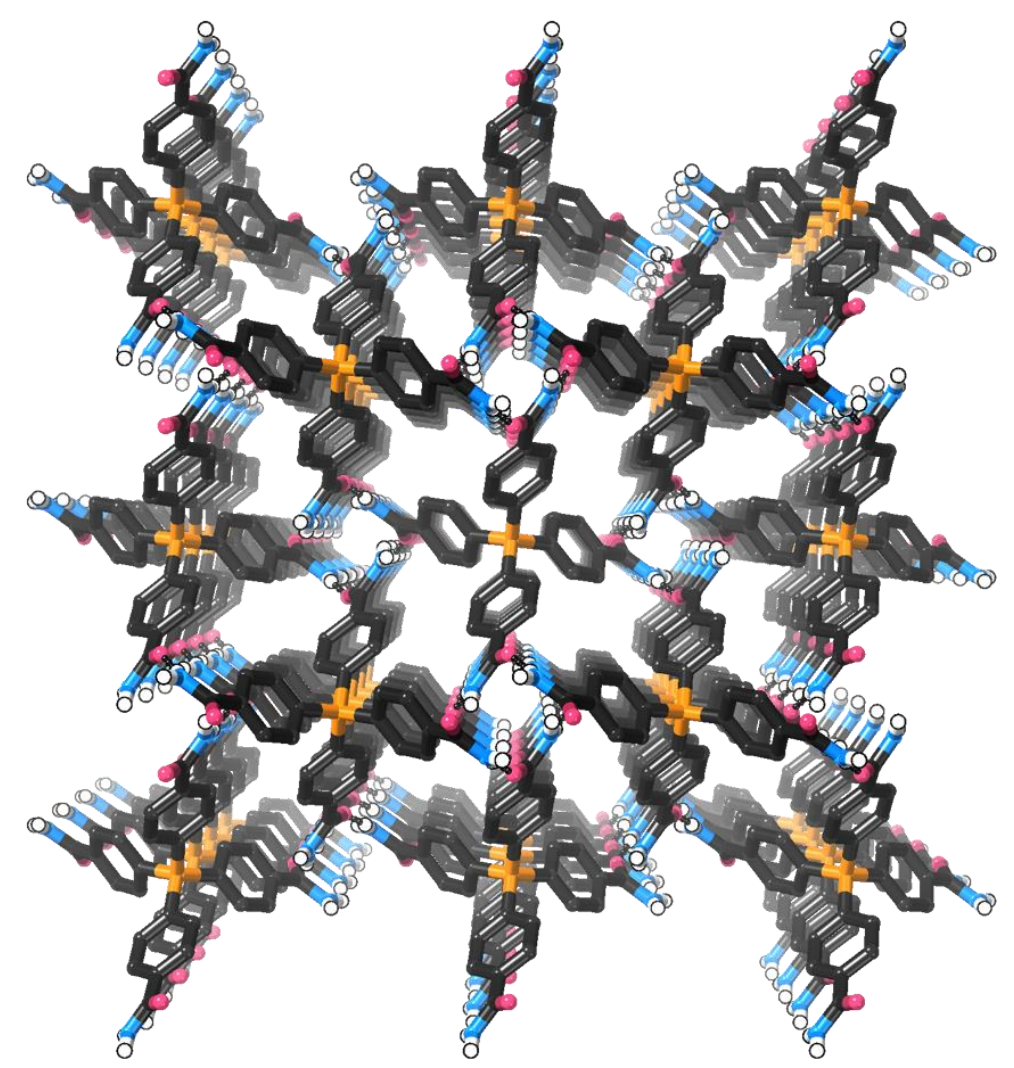

Figure S3. Diagram showing the packing of 5 down the $\mathrm{c}$-axis $(\mathrm{C}-\mathrm{H}$ hydrogen atoms are omitted for clarity).

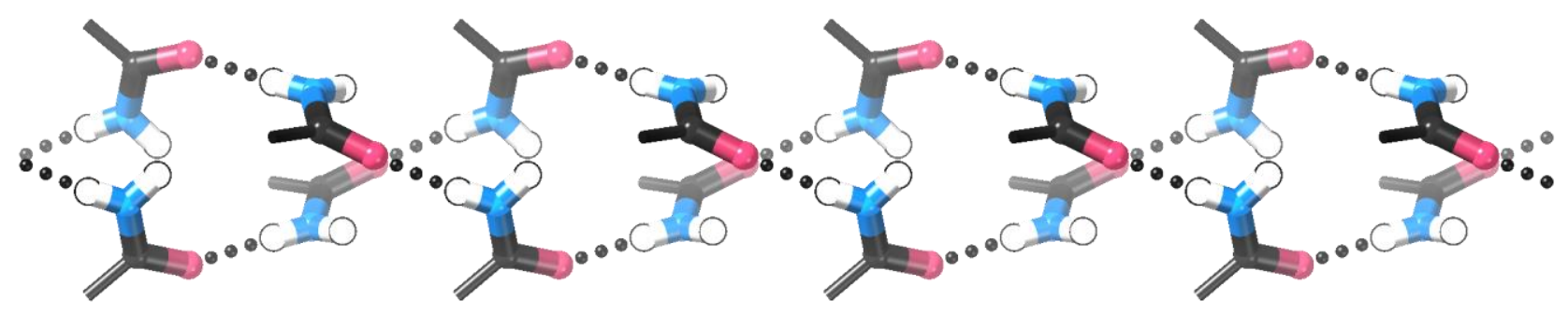

Figure S4. Diagram showing the double helical hydrogen bonding arrangement of $\mathbf{5}$. 


\section{Details of structures and refinements}

Data for these structures were collected on either an Agilent Xcalibur diffractometer using Mo Ka radiation (1.CI), an Agilent SuperNova diffractomer using Cu Ka radiation (4) or an Agilent SuperNova diffractometer using Mo Ka radiation (5).

Raw frame data (including data reduction, interframe scaling, unit cell refinement and absorption corrections) were processed using CrysAlisPro. ${ }^{\text {S2 }}$ The structures were solved with SUPERFLIPS3 and refined using full-matrix least-squares on $F^{2}$ within the CRYSTALS suite. ${ }^{S 4}$ All non-hydrogen atoms were refined with anisotropic displacement parameters. $\mathrm{C}-\mathrm{H}$ hydrogen atoms were visible in the Fourier difference map, and were initially refined with restraints on bond lengths and angles, after which the positions were used as the basis for a riding model. ${ }^{\mathrm{S}} \mathrm{N}-\mathrm{H}$ and $\mathrm{O}-\mathrm{H}$ hydrogen atoms were visible in the Fourier difference map and their positions were refined with restraints on bond lengths and angles. ${ }^{55}$ Apart from these restraints on hydrogen atoms, it was not necessary to add any crystallographic restraints to these refinements.

Thermal ellipsoid plots are provided in Figures S5-S7, and crystallographic data are summarized in Table S1.

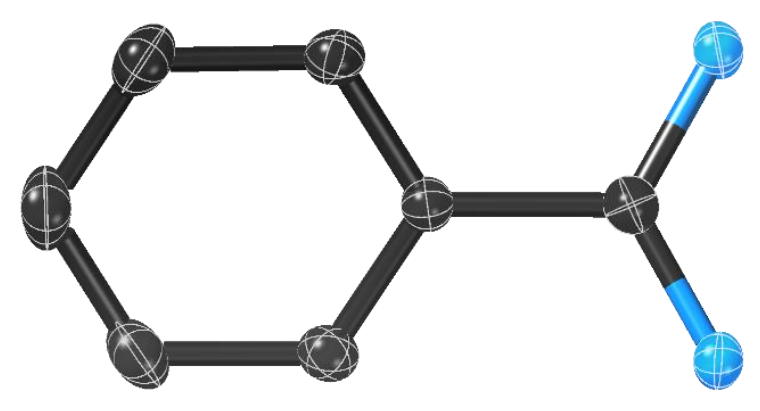

Figure S5. Thermal ellipsoid plot of the asymmetric unit of $\mathbf{1 \cdot C l}$ (ellipsoids shown at $50 \%$ probability, hydrogen atoms omitted for clarity).

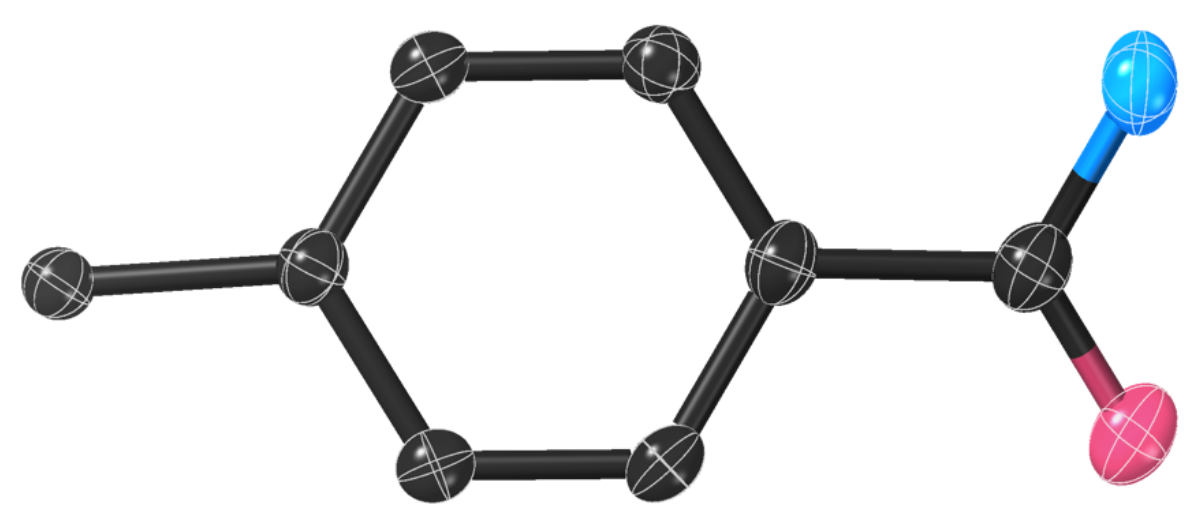

Figure S6. Thermal ellipsoid plot of the asymmetric unit of $\mathbf{4}$ (ellipsoids shown at 50\% probability, hydrogen atoms omitted for clarity). 


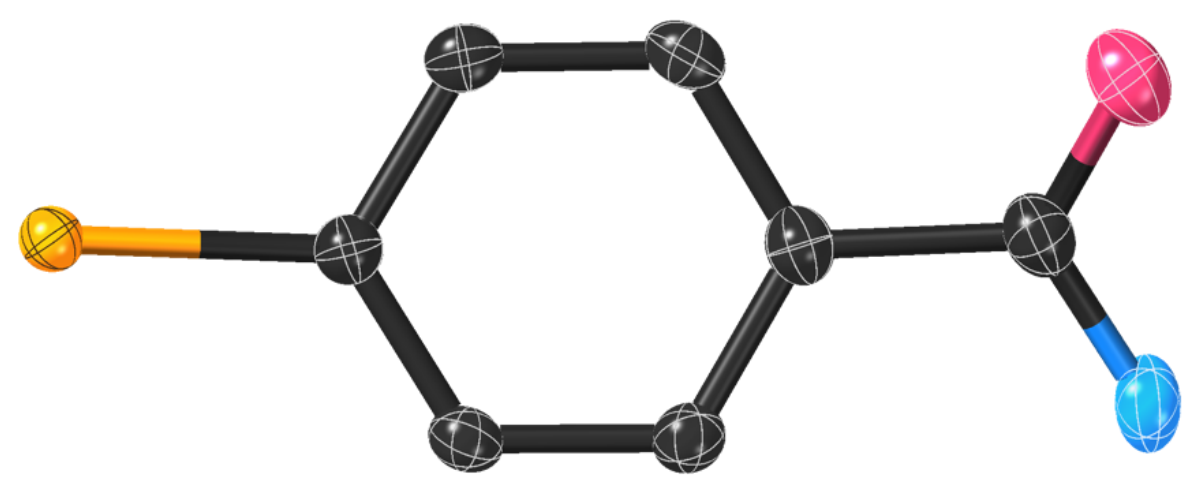

Figure S7. Thermal ellipsoid plot of the asymmetric unit of $\mathbf{5}$ (ellipsoids shown at $50 \%$ probability, hydrogen atoms omitted for clarity).

Table S1. Selected crystallographic data.

\begin{tabular}{|c|c|c|c|}
\hline Compound & $1 \cdot \mathrm{Cl} \cdot 2 \mathrm{H}_{2} \mathrm{O}$ & 4 & 5 \\
\hline Radiation type & $\operatorname{Mo}(\lambda=0.71073 \AA)$ & $\mathrm{Cu}(\lambda=1.54184 \AA)$ & Mo $(\lambda=0.71073 \AA)$ \\
\hline Formula & $\mathrm{C}_{7} \mathrm{H}_{9} \mathrm{~N}_{2} \cdot \mathrm{Cl} \cdot 2\left(\mathrm{H}_{2} \mathrm{O}\right)$ & $\mathrm{C}_{29} \mathrm{H}_{24} \mathrm{~N}_{4} \mathrm{O}_{4}$ & $\mathrm{C}_{28} \mathrm{H}_{24} \mathrm{~N}_{4} \mathrm{O}_{4} \mathrm{Si}$ \\
\hline Formula weight & 192.65 & 492.53 & 508.61 \\
\hline$a(\AA)$ & $8.4809(4)$ & $12.4807(3)$ & 12.69969(2) \\
\hline$b(\AA)$ & $7.0559(3)$ & $12.4807(3)$ & 12.69969(2) \\
\hline$c(\AA)$ & $16.4724(8)$ & $7.6749(2)$ & $7.72304(2)$ \\
\hline$\alpha(\stackrel{\circ}{)})$ & 90 & 90 & 90 \\
\hline$\beta(\stackrel{\circ}{\circ})$ & $95.424(4)$ & 90 & 90 \\
\hline$Y(\stackrel{\circ}{=})$ & 90 & 90 & 90 \\
\hline Unit cell volume $\left(\AA^{3}\right)$ & $981.30(8)$ & $1195.50(4)$ & $1245.588(5)$ \\
\hline Crystal system & Monoclinic & tetragonal & tetragonal \\
\hline Space group & $P 2_{1} / C$ & $P 4_{2} / n$ & $P 4_{2} / n$ \\
\hline$z$ & 4 & 2 & 2 \\
\hline Reflections (all) & 8521 & 18591 & 4944 \\
\hline Reflections (unique) & 2005 & 1210 & 1267 \\
\hline$R_{\text {int }}$ & 0.025 & 0.054 & 0.023 \\
\hline$R_{1}[I>2 \sigma(I)]$ & 0.026 & 0.045 & 0.041 \\
\hline$w R_{2}\left(F^{2}\right)$ (all data) & 0.063 & 0.097 & 0.092 \\
\hline CCDC number & 2102924 & 2102922 & 2102923 \\
\hline
\end{tabular}




\section{${ }^{1} \mathrm{H}$ NMR experiments}

\section{Spectra of $1 \cdot \mathrm{Cl}$}

The ${ }^{1} \mathrm{H}$ NMR spectrum of $1 \cdot \mathrm{Cl}$ in $\mathrm{d}_{6}$-DMSO is shown in Figure S8. In this solvent, the three $\mathrm{C}-\mathrm{H}$ and two $\mathrm{N}-\mathrm{H}$ resonances are well-resolved.

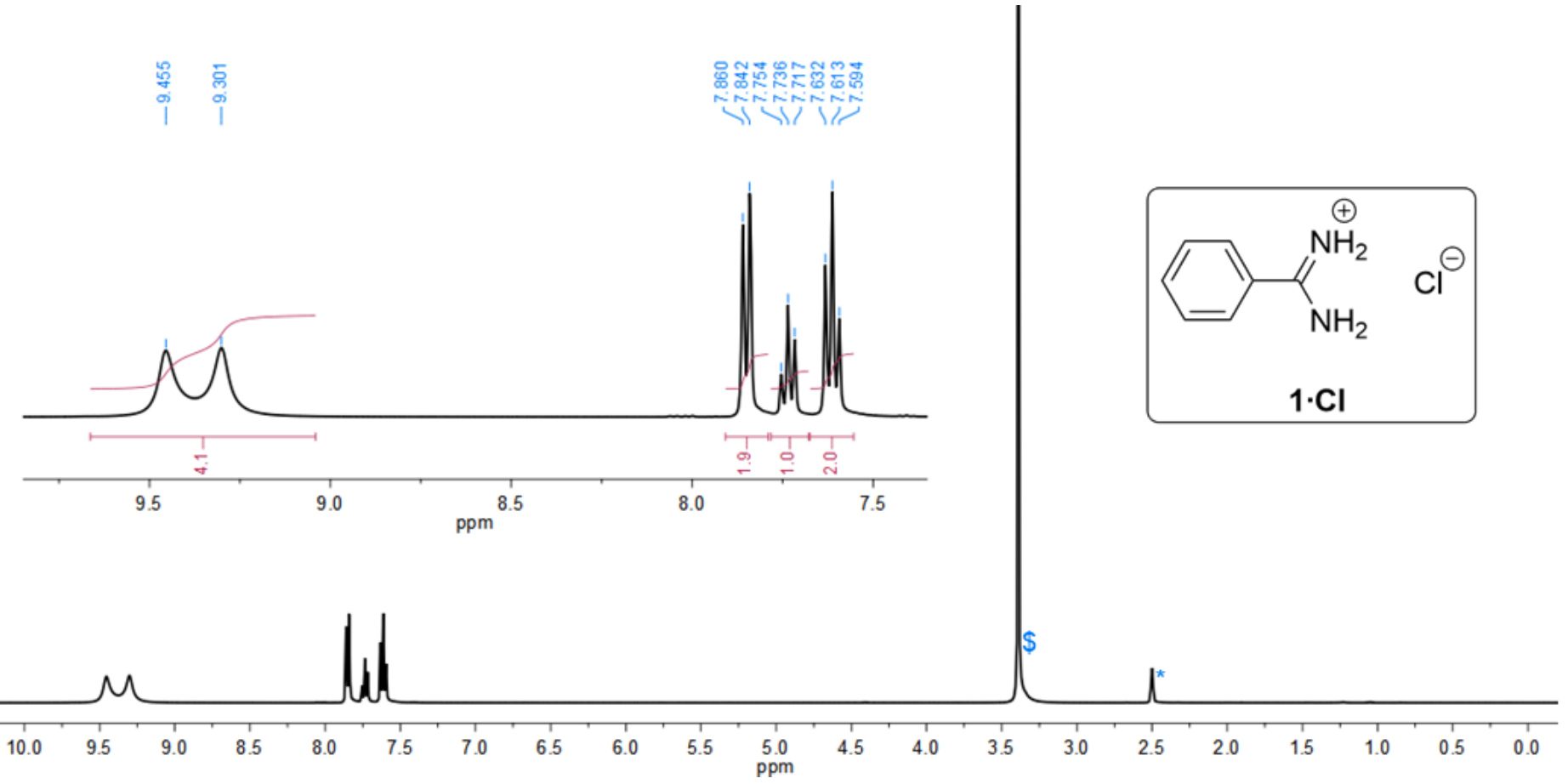

Figure S8 ${ }^{1} \mathrm{H}$ NMR spectrum of $\mathbf{1} \cdot \mathbf{C l}$; * represents $d_{5}$-DMSO residual solvent peak, $\$$ represents water peak, which has been truncated $(50 \mathrm{mM}$, $298 \mathrm{~K}, 400 \mathrm{MHz}, \mathrm{d}_{6}$-DMSO). 
In $\mathrm{D}_{2} \mathrm{O}$, which was used for the hydrolysis studies, peak overlap is observed and the $\mathrm{N}-\mathrm{H}$ resonances are absent due to $\mathrm{H} / \mathrm{D}$ exchange. Nevertheless, peak integrations could be determined with some level of confidence for both $\mathbf{1} \cdot \mathbf{C l}$ and the hydrolysis product, benzamide. As expected, the peak position shows a dependence on pH (Figure S9), particularly close to the $\mathrm{p} K_{\mathrm{a}}$ of benzamidinium (11.6). ${ }^{\mathrm{s} 6}$

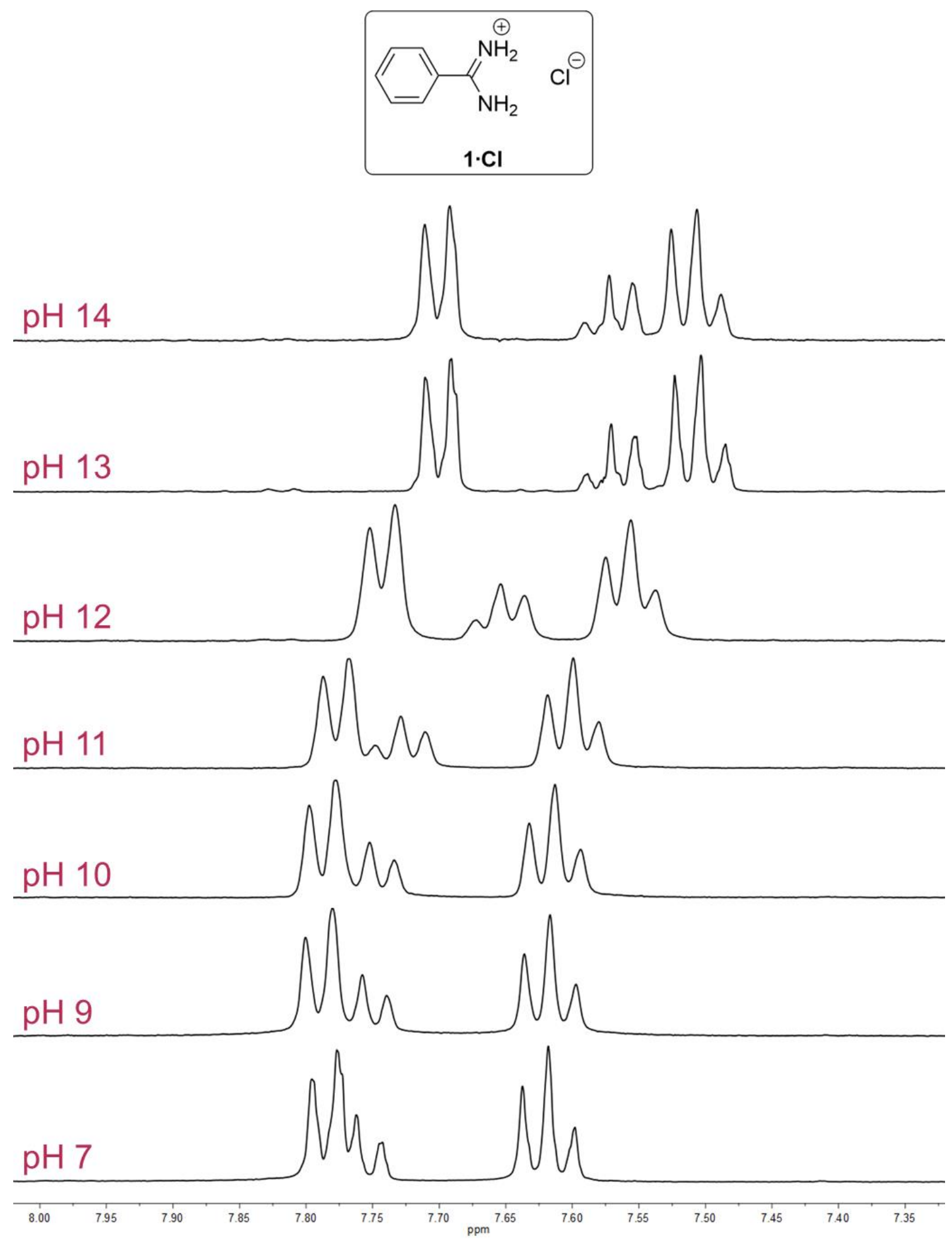

Figure S9. Truncated ${ }^{1} \mathrm{H}$ NMR spectra of $1 \cdot \mathrm{Cl}$ at different pHs $\left(10 \mathrm{mM} 1 \cdot \mathrm{Cl}, \mathrm{D}_{2} \mathrm{O}, 298 \mathrm{~K}, 400 \mathrm{MHz}\right)$. The pH 7 spectrum is neat $\mathrm{D}_{2} \mathrm{O}$, the spectra at $\mathrm{pH}$ 9-12 are $100 \mathrm{mM}$ phosphate buffer in $\mathrm{D}_{2} \mathrm{O}$, and the $\mathrm{pH} 13$ and 14 spectra are 0.10 or $1.0 \mathrm{M} \mathrm{NaOH}$ in $\mathrm{D}_{2} \mathrm{O}$, respectively. 
The ${ }^{1} \mathrm{H}$ NMR spectrum of ${ }^{1} \cdot \mathbf{C l}$ after 3 months in $\mathrm{D}_{2} \mathrm{O}$ is compared with the initial ${ }^{1} \mathrm{H}$ NMR spectrum of $1 \cdot \mathrm{Cl}$ in Figures $\mathrm{S} 10$ and $\mathrm{S} 11$. No change is evident, consistent with $\mathbf{1} \cdot \mathrm{Cl}$ being stable in the absence of base.

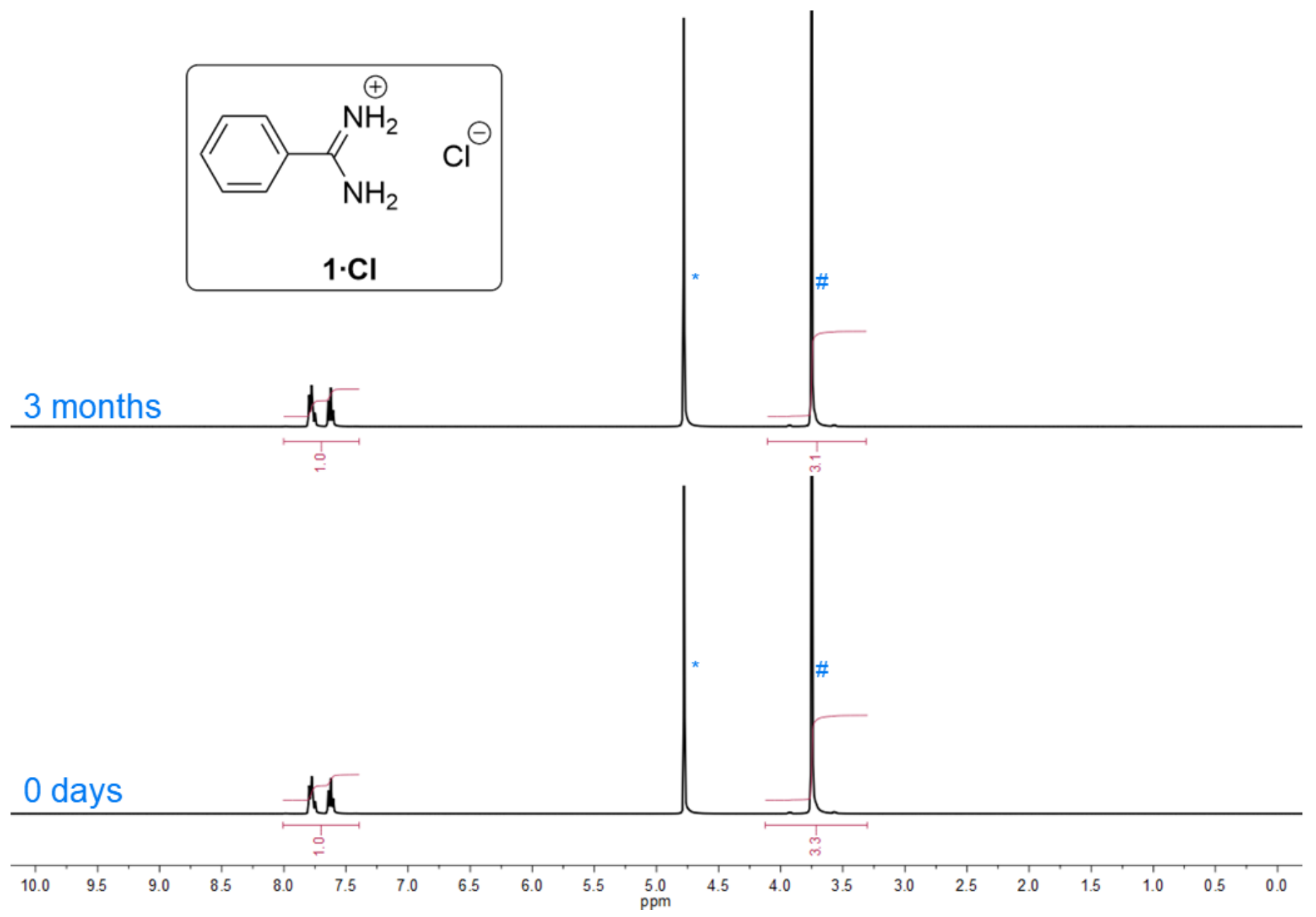

Figure S10. ${ }^{1} \mathrm{H}$ NMR spectra of $\mathbf{1} \cdot \mathbf{C l}$ after 0 days, and after 3 months in $D_{2} \mathrm{O}$ at room temperature; * represents HOD peak, \# represents $1,4-$ dioxane added as reference peak, which has been truncated $\left(50 \mathrm{mM}, 298 \mathrm{~K}, 400 \mathrm{MHz}, \mathrm{D}_{2} \mathrm{O}\right)$.

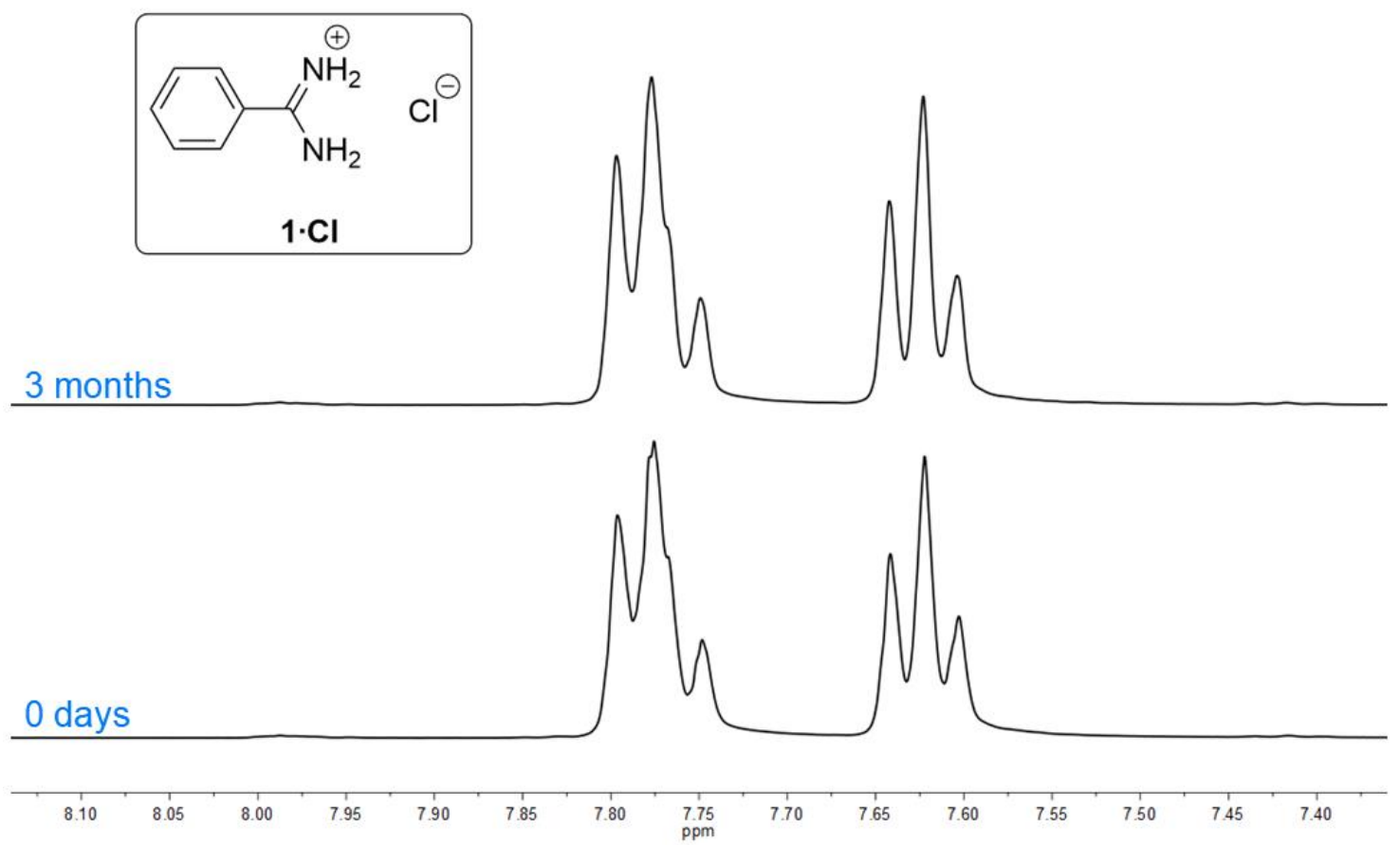

Figure S11. Truncated ${ }^{1} \mathrm{H}$ NMR spectra of $\mathbf{1} \cdot \mathbf{C l}$ after 0 days, and after 3 months in $\mathrm{D}_{2} \mathrm{O}$ at room temperature $\left(50 \mathrm{mM}, 298 \mathrm{~K}, 400 \mathrm{MHz}, \mathrm{D}_{2} \mathrm{O}\right)$. 


\section{Susceptibility of $1 \cdot \mathrm{Cl}$ to oxidation}

Solutions of $1 \cdot \mathrm{Cl}$ in $\mathrm{D}_{2} \mathrm{O}$ in a capped NMR tube did not show any evidence of oxidation. Given the relatively small volume of air in a capped NMR tube, we also investigated the stability of $1 \cdot \mathrm{Cl}$ in oxygen-saturated $\mathrm{D}_{2} \mathrm{O}$. Oxygen gas was bubbled through a solution of $\mathrm{D}_{2} \mathrm{O}$ for five minutes, and this was immediately used to prepare a solution of $1 \cdot \mathrm{Cl}$. This solution was rapidly transferred to an NMR tube, and the tube capped and sealed with laboratory film. No evidence of any oxidation was observed over several months by either ${ }^{1} \mathrm{H}$ NMR spectroscopy or mass spectrometry. We therefore conclude that

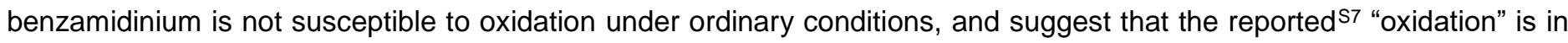
fact more likely to be hydrolysis.

\section{General procedure for hydrolysis experiments}

Solutions of base/buffer were added to solid $\mathbf{1} \cdot \mathbf{C l}, \mathbf{2} \cdot \mathrm{Cl}_{4}$ or $\mathbf{6} \cdot \mathrm{Cl}_{2}$ to give $10 \mathrm{mM}$ solutions. Approximately $0.5 \mathrm{~mL}$ of these solutions were placed in an NMR tube, the tube was capped and sealed with parafilm, and then left to stand at room temperature. ${ }^{1} \mathrm{H}$ NMR spectra were collected at various timepoints.

${ }^{1} \mathrm{H}$ NMR spectroscopy revealed that the amidiniums hydrolysed to amides. In the more basic solutions, evidence of subsequent hydrolysis to the carboxylate was also observed (particularly in $1.0 \mathrm{M} \mathrm{NaOH}_{(\text {aq) }}$ ). Mass spectrometry was consistent with the formation of amides, and no evidence for the oxidised amidoxime was observed by mass spectrometry. X-ray crystal structures were obtained of the tetra-amide 4 and of previously reported terephthalamide (obtained by hydrolysis of $\mathbf{6} \cdot \mathbf{C l}_{2}, \mathrm{CCDC}$ : 1275774 for previously reported structure of terephthalamide ${ }^{\mathrm{s}}$ ) further support the proposed products.

Estimates of the standard error of the regression are provided, however these only account for the error and not any systematic errors. In our case, the most likely source of substantial error is temperature fluctuation. Samples were stored in the laboratory, which while climate controlled, exhibits significant variation relative to the intended temperature (295 K). Additionally, while NMR samples were run at $298 \mathrm{~K}$, the room housing the NMR spectrometer is significantly colder than this in winter so samples waiting in the NMR autosampler may have been colder than expected for prolonged periods. We conservatively estimate that the real errors are in the region of $10-20 \%$. We emphasize that the point of these measurements is to allow for the determination of trends and so moderate-sized errors in the rate constants do not affect the conclusions of this work. 


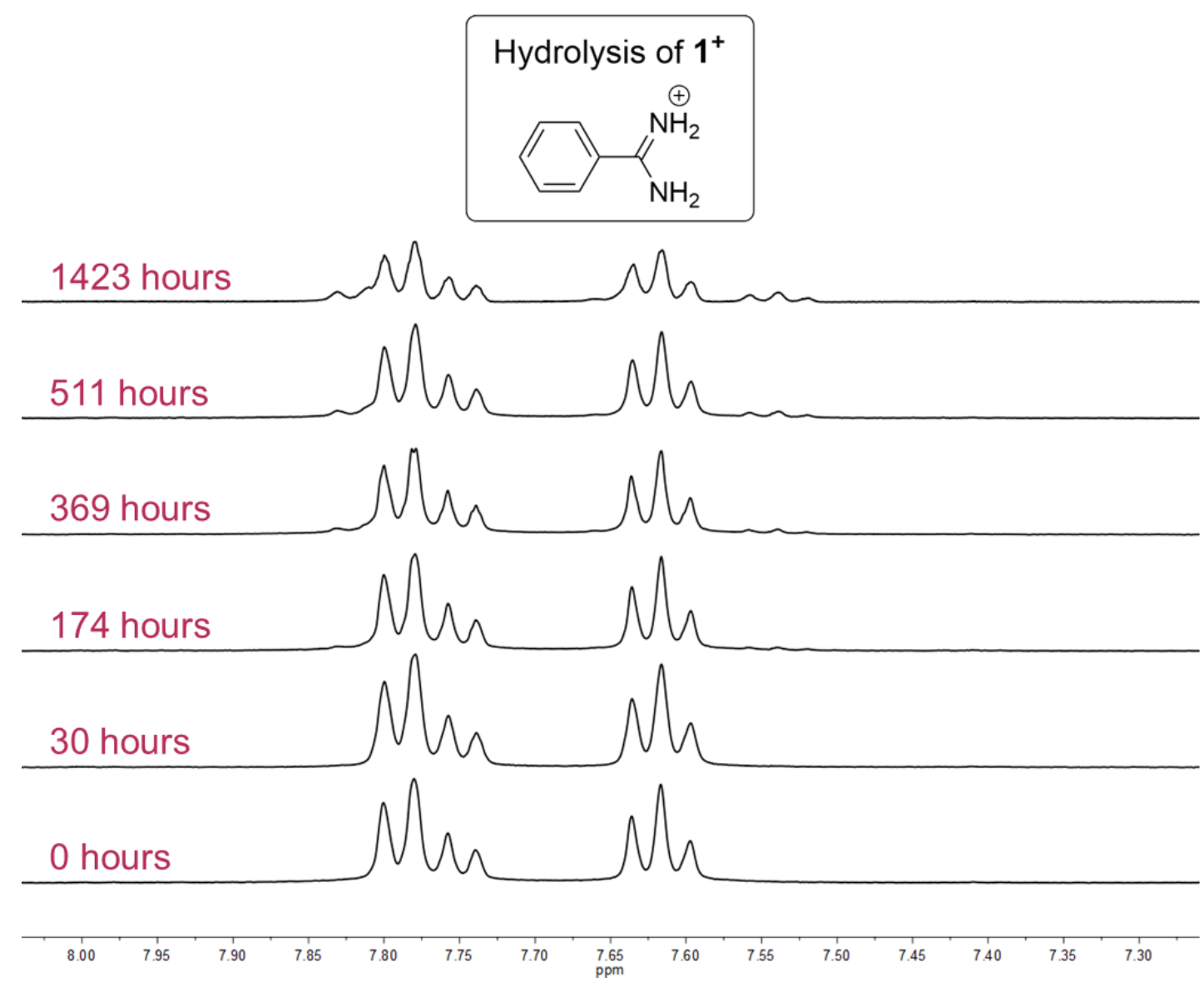

Figure S12. Truncated ${ }^{1} \mathrm{H}$ NMR spectra of $\mathbf{1} \cdot \mathbf{C l}$ at various timepoints in buffer at $\mathrm{pH} 9(10 \mathrm{mM}$ with $100 \mathrm{mM}$ phosphate buffer, room temperature, $\left.400 \mathrm{MHz}, \mathrm{D}_{2} \mathrm{O}\right)$.

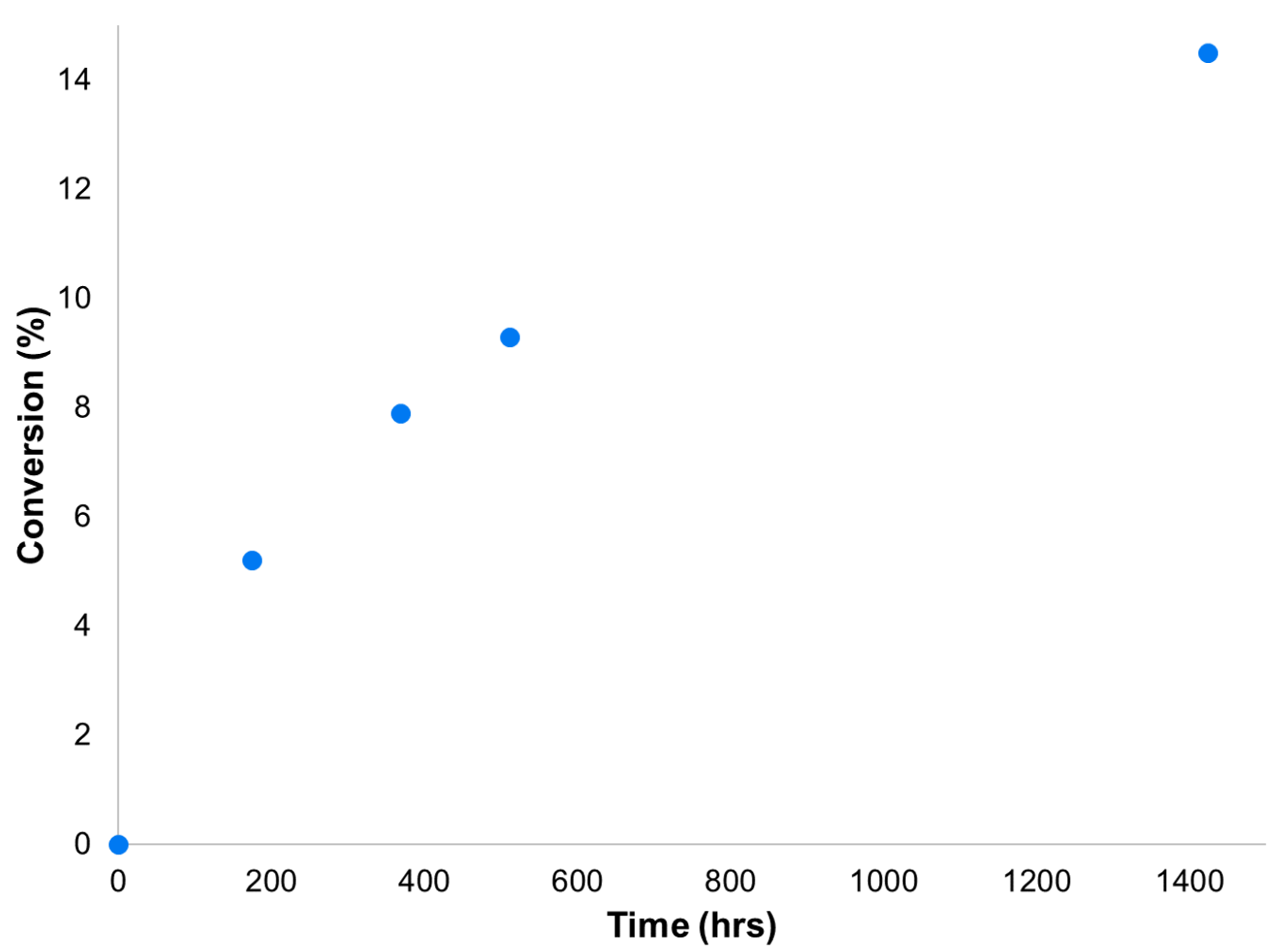

Figure S13. Conversion of $\mathbf{1} \cdot \mathbf{C l}$ to benzamide over time at $\mathrm{pH} 9(10 \mathrm{mM}$ in $100 \mathrm{mM}$ aqueous phosphate buffer, room temperature). 


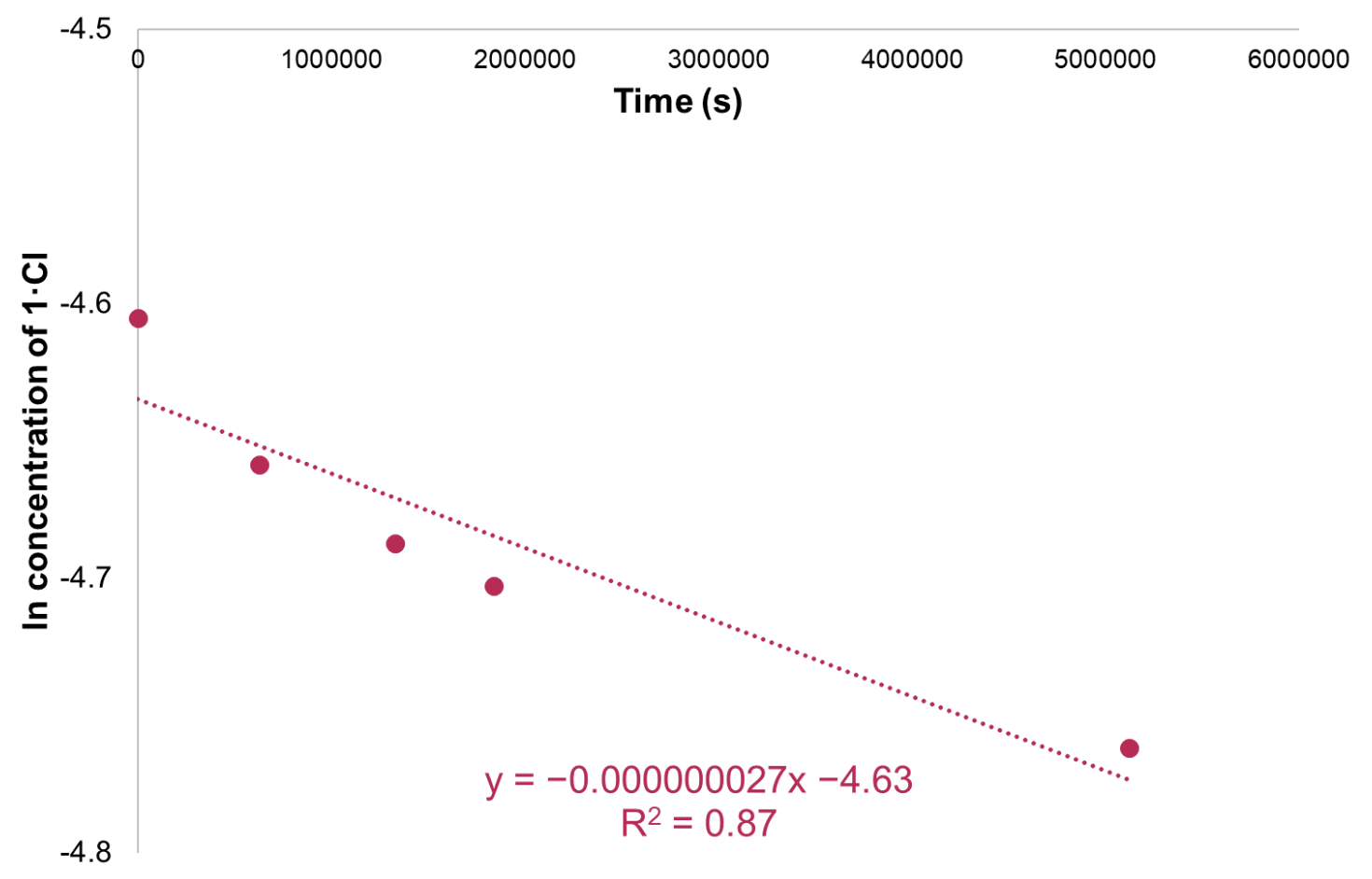

Figure S14. Concentration of $\mathbf{1 \cdot C l}$ over time at pH $9(10 \mathrm{mM}$ in $100 \mathrm{mM}$ aqueous phosphate buffer, room temperature).

Slope: $-2.7 \times 10^{-8}$

Estimated standard error of regression of slope: $5.9 \times 10^{-9}$

Intercept: -4.63

Estimated standard error of regression of intercept: 0.015

$\mathbf{R}^{2}: 0.874$ 


\section{Hydrolysis of $\mathbf{1}^{+}$}

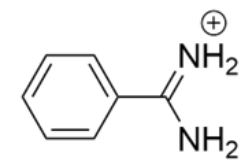

1423 hours

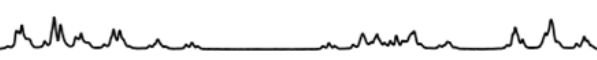

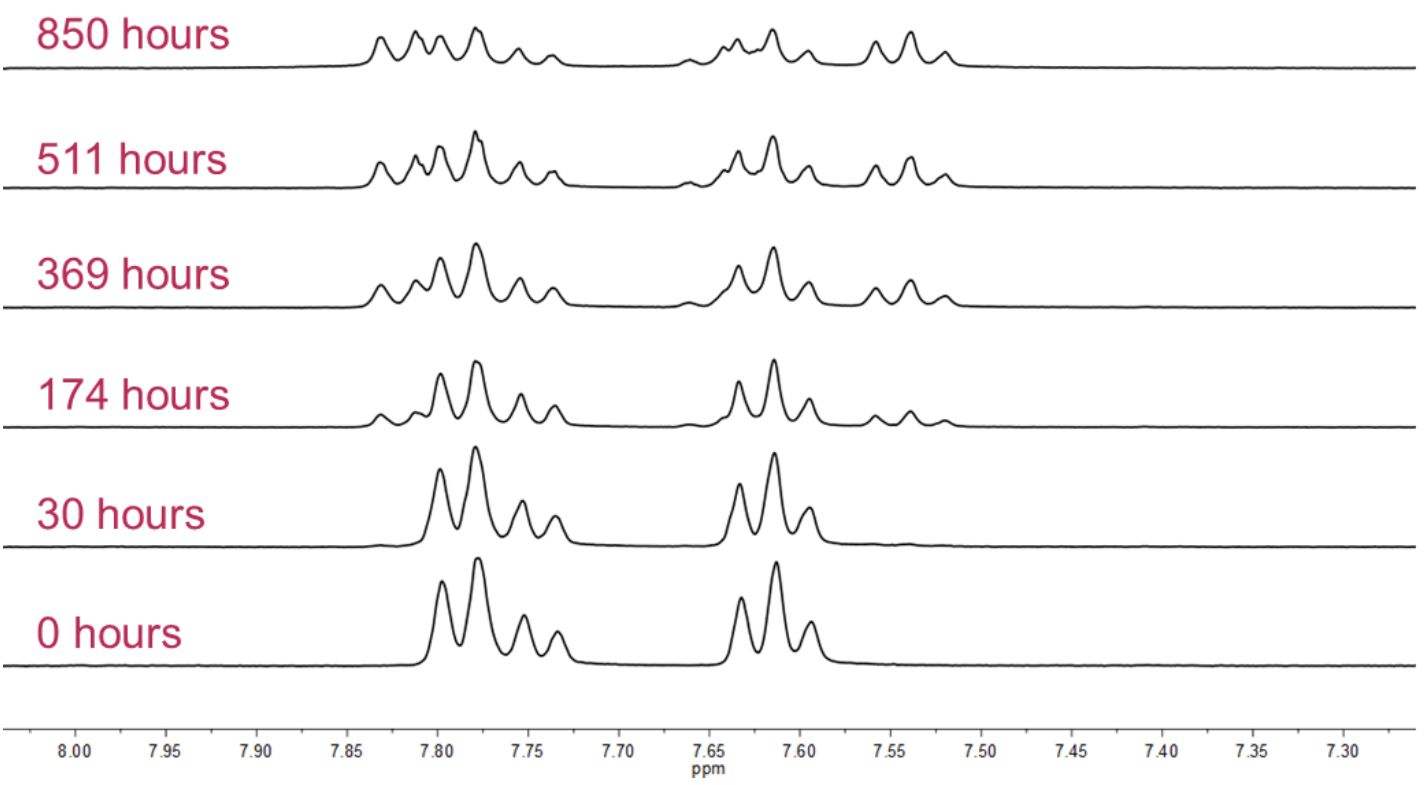

Figure S15. Truncated ${ }^{1} \mathrm{H}$ NMR spectra of $1 \cdot \mathbf{C l}$ at various timepoints in buffer at $\mathrm{pH} 10(10 \mathrm{mM}$ with $100 \mathrm{mM}$ phosphate buffer, room temperature, $400 \mathrm{MHz}, \mathrm{D}_{2} \mathrm{O}$ ).

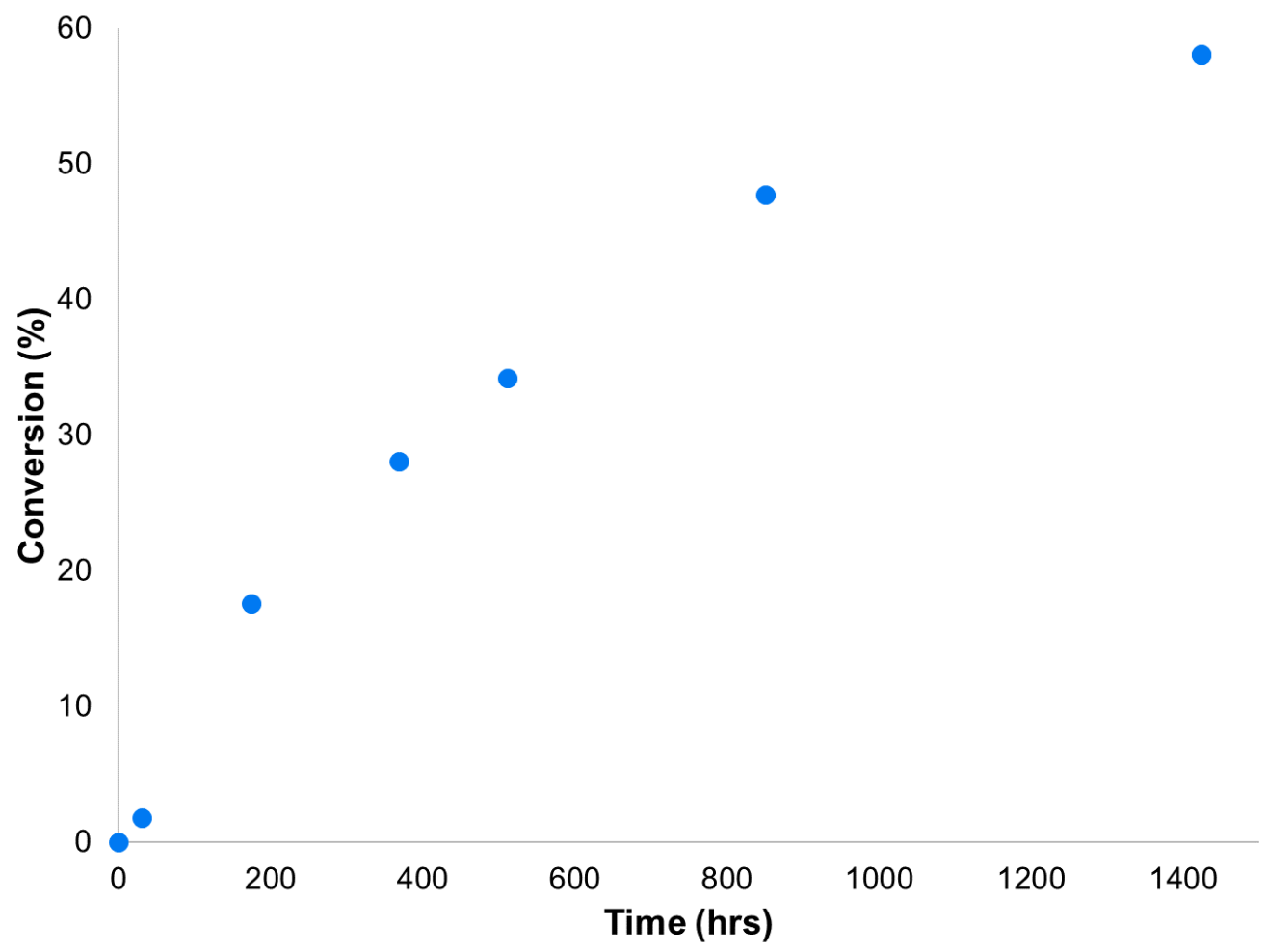

Figure S16. Conversion of $1 \cdot \mathbf{C l}$ to benzamide over time at $\mathrm{pH} 10$ (10 mM in $100 \mathrm{mM}$ aqueous phosphate buffer, room temperature). 


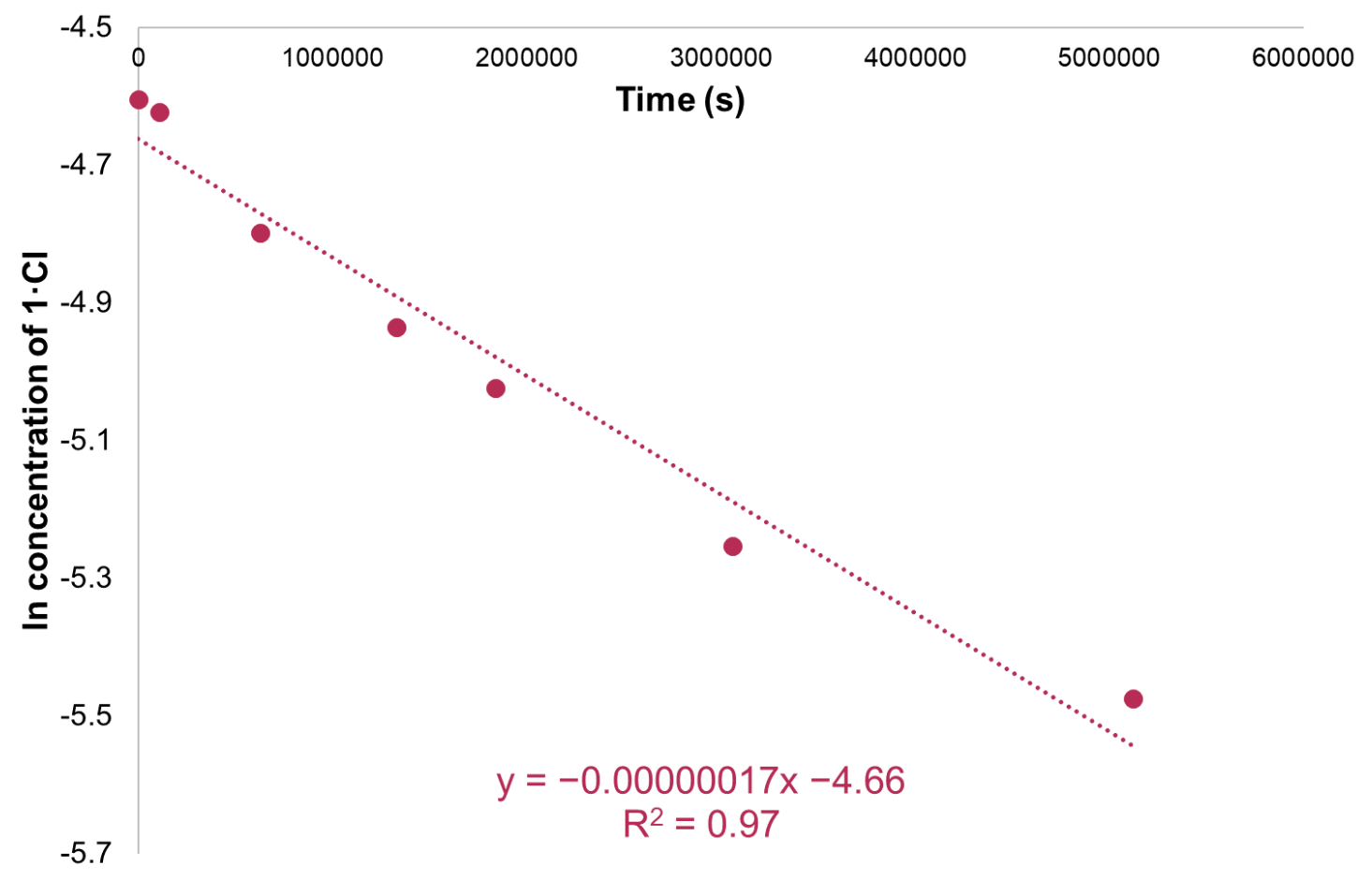

Figure S17. Conversion of $\mathbf{1} \cdot \mathbf{C l}$ to benzamide over time at $\mathrm{pH} 10(10 \mathrm{mM}$ in $100 \mathrm{mM}$ aqueous phosphate buffer, room temperature).

Slope: $-1.7 \times 10^{-7}$

Estimated standard error of regression of slope: $1.4 \times 10^{-8}$

Intercept: -4.66

Estimated standard error of regression of intercept: 0.034

$\mathbf{R}^{2}: 0.967$ 


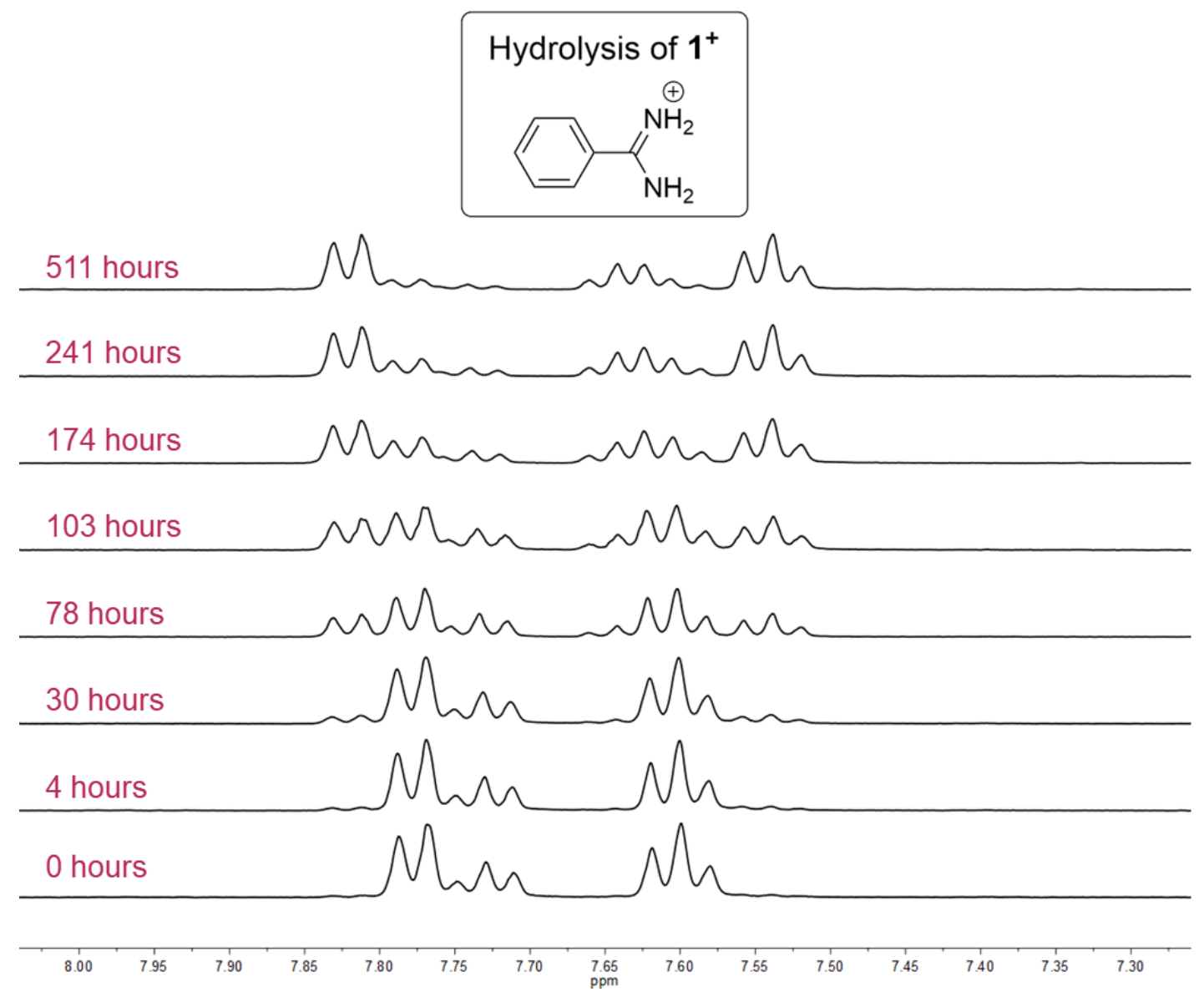

Figure S18. Truncated ${ }^{1} \mathrm{H}$ NMR spectra of $1 \cdot \mathrm{Cl}$ at various timepoints in buffer at $\mathrm{pH} 11(10 \mathrm{mM}$ with $100 \mathrm{mM}$ phosphate buffer, room temperature, $\left.400 \mathrm{MHz}, \mathrm{D}_{2} \mathrm{O}\right)$.

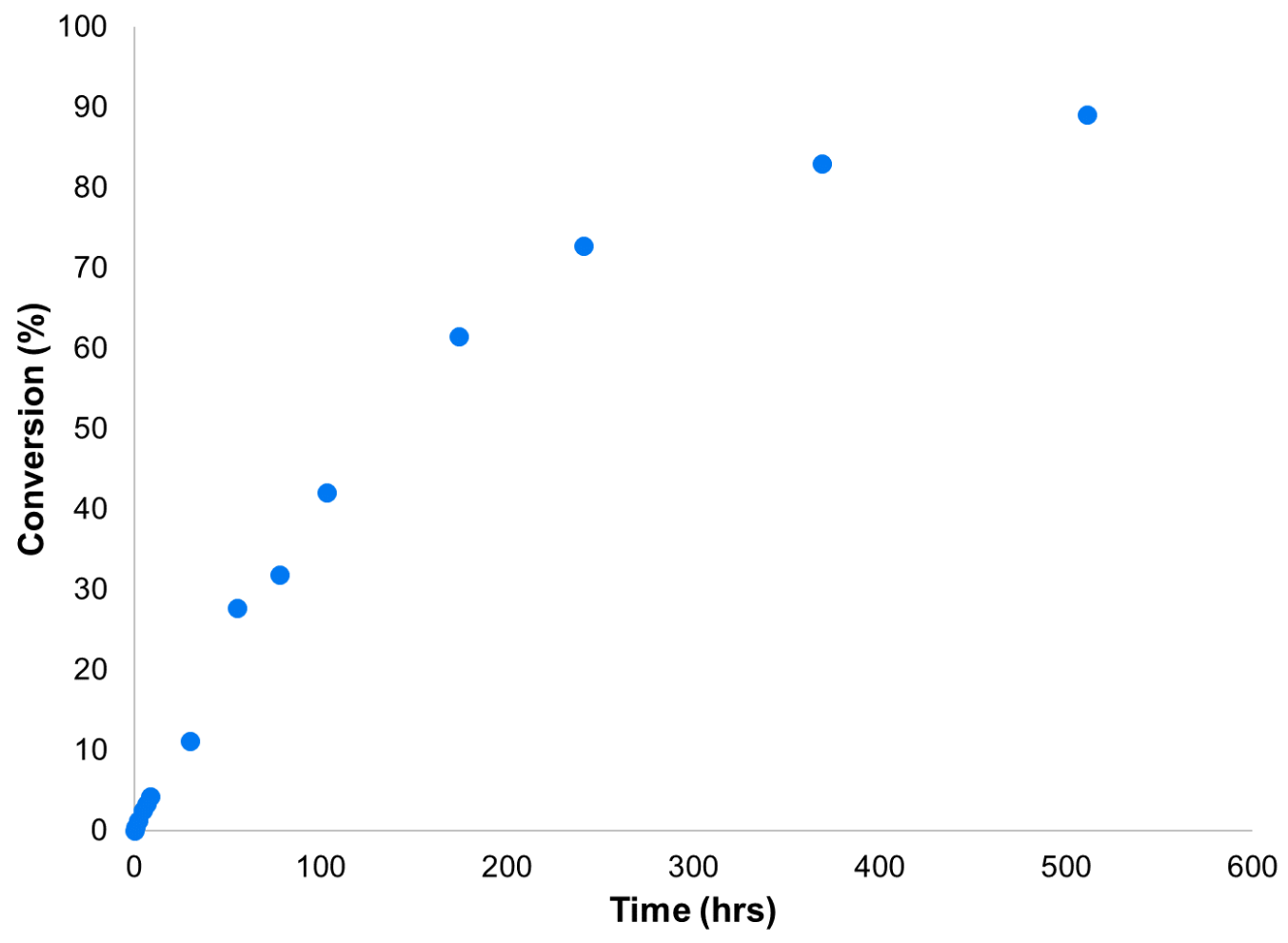

Figure S19. Conversion of $\mathbf{1} \cdot \mathbf{C l}$ to benzamide over time at $\mathrm{pH} 11$ (10 mM in $100 \mathrm{mM}$ aqueous phosphate buffer, room temperature). 


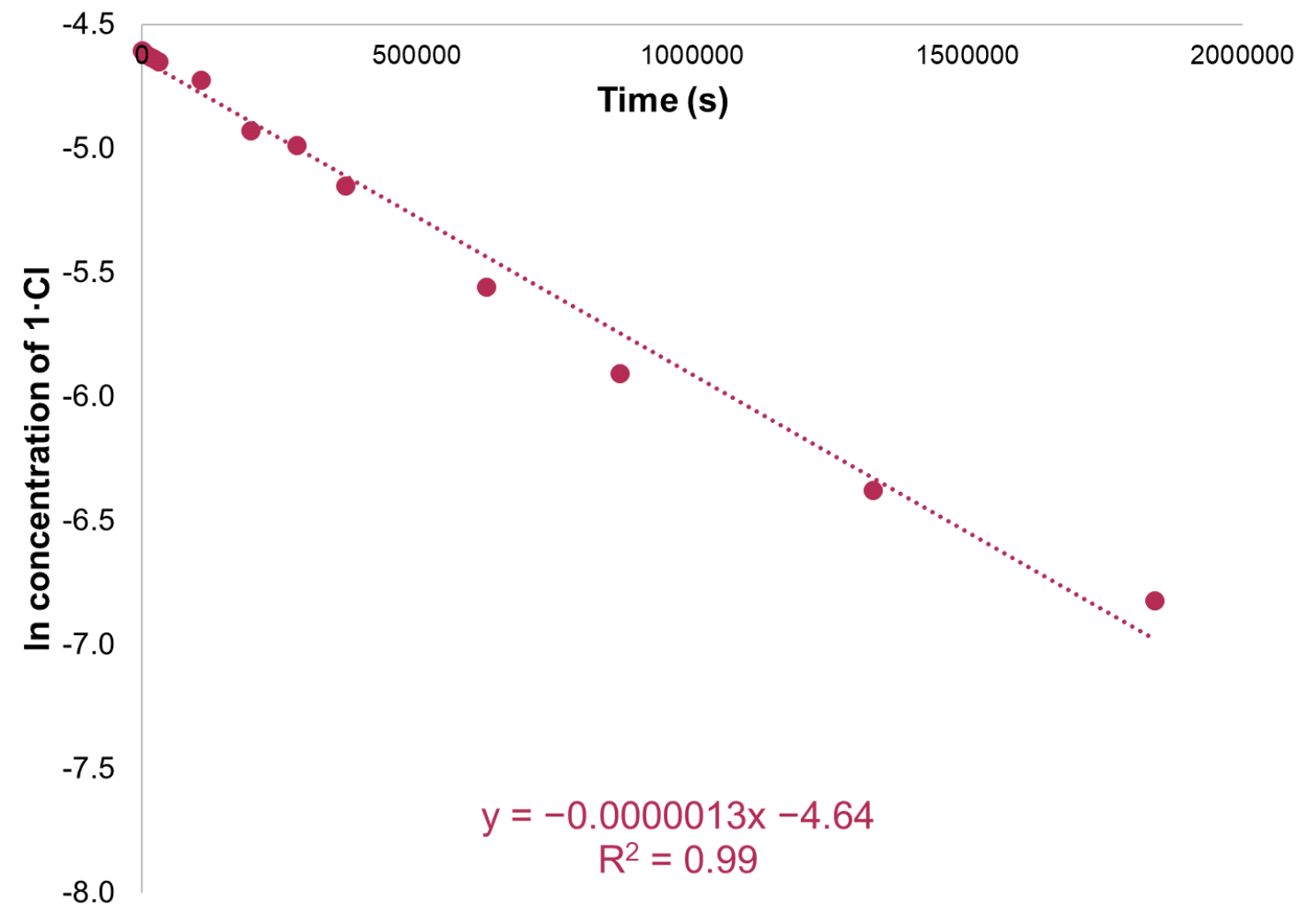

Figure S20. Conversion of $\mathbf{1} \cdot \mathbf{C l}$ to benzamide over time at pH 11 (10 mM in $100 \mathrm{mM}$ aqueous phosphate buffer, room temperature).

Slope: $-1.3 \times 10^{-6}$

Estimated standard error of regression of slope: $4.0 \times 10^{-8}$

Intercept: -4.64

Estimated standard error of regression of intercept: 0.027

$\mathbf{R}^{2}: 0.988$ 


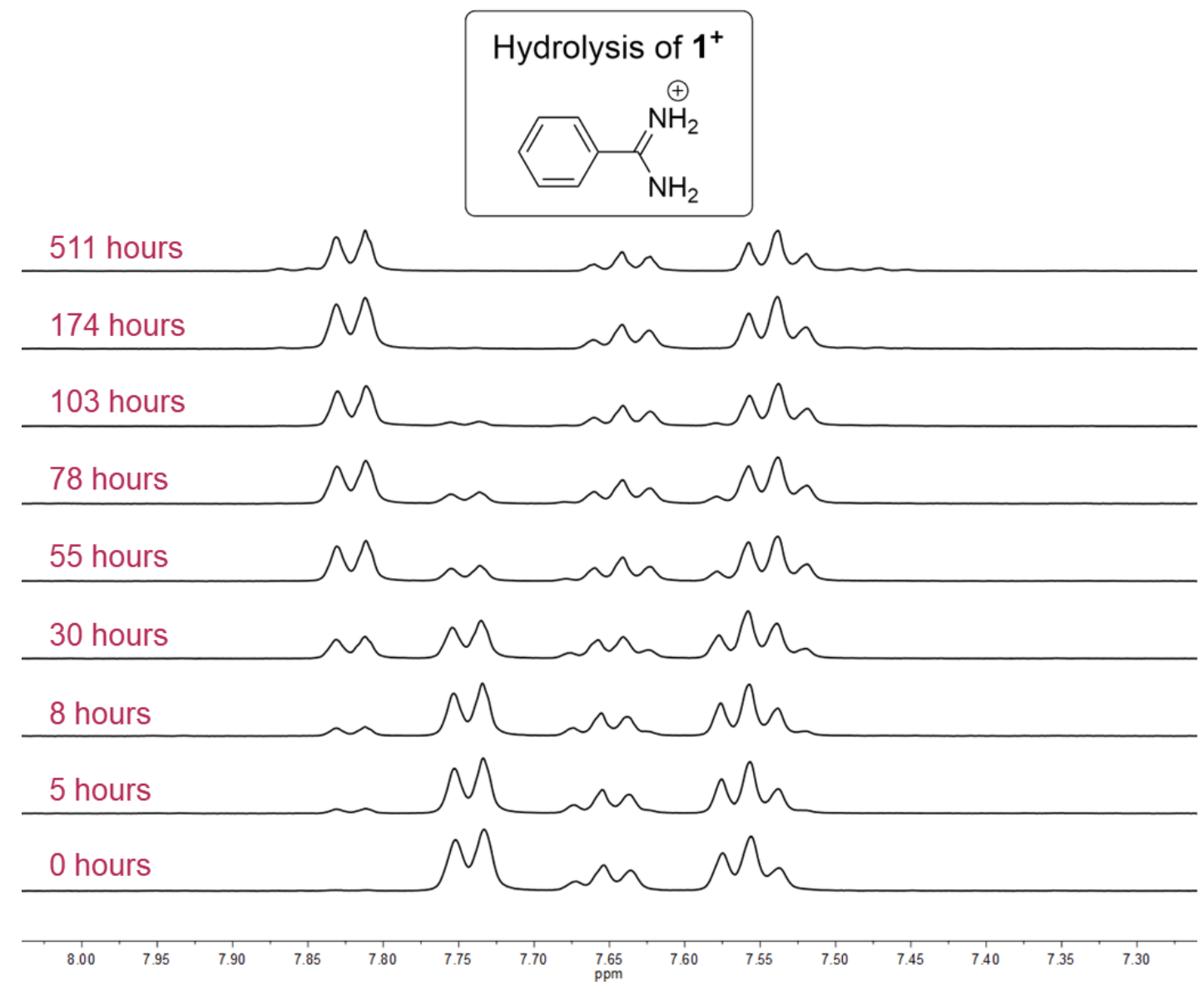

Figure S21. Truncated ${ }^{1} \mathrm{H}$ NMR spectra of $1 \cdot \mathrm{Cl}$ at various timepoints in buffer at $\mathrm{pH} 12(10 \mathrm{mM}$ with $100 \mathrm{mM}$ phosphate buffer, room temperature, $\left.400 \mathrm{MHz}, \mathrm{D}_{2} \mathrm{O}\right)$.

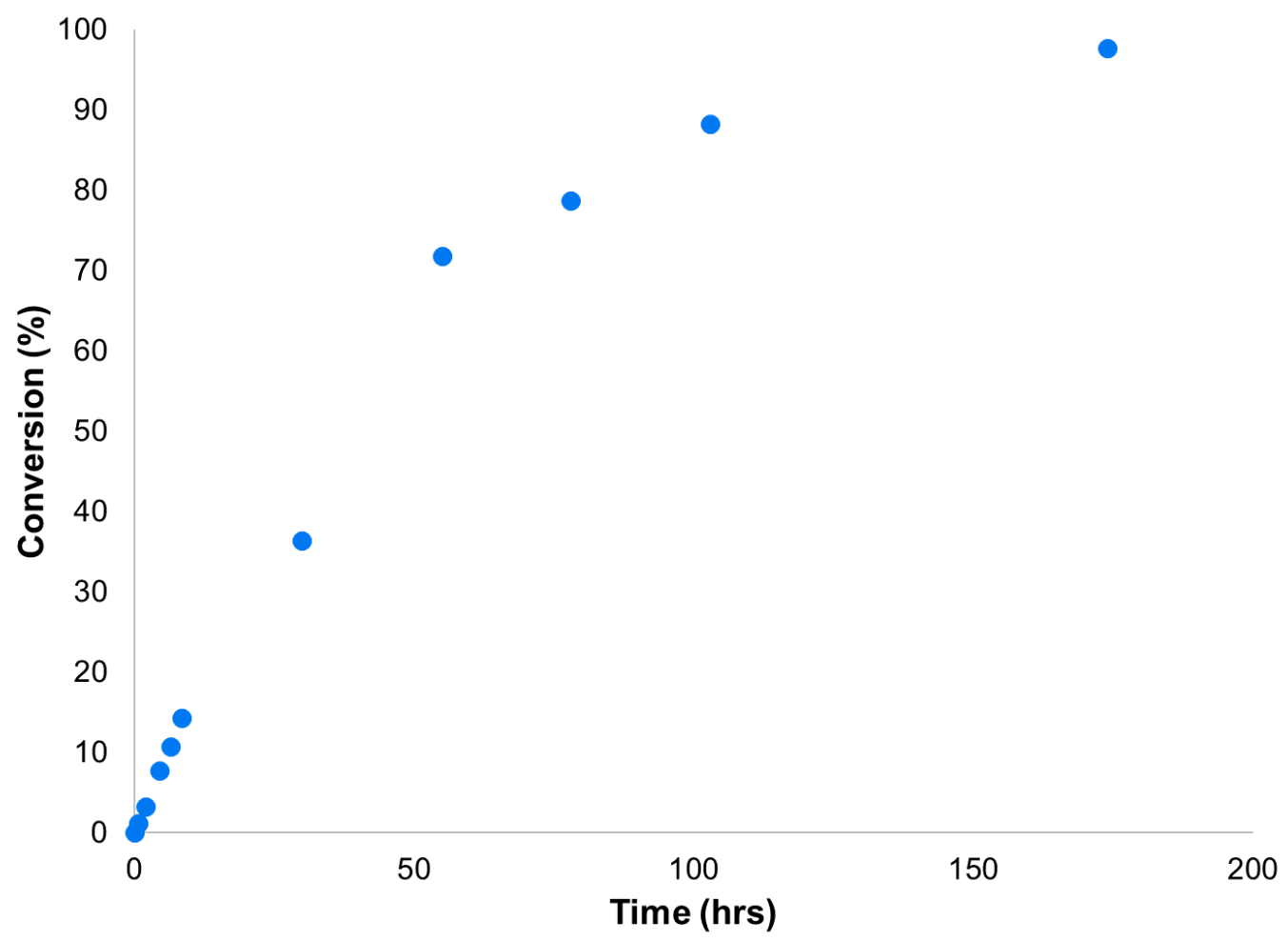

Figure S22. Conversion of $1 \cdot \mathbf{C l}$ to benzamide over time at $\mathrm{pH} 12(10 \mathrm{mM}$ in $100 \mathrm{mM}$ aqueous phosphate buffer, room temperature). 


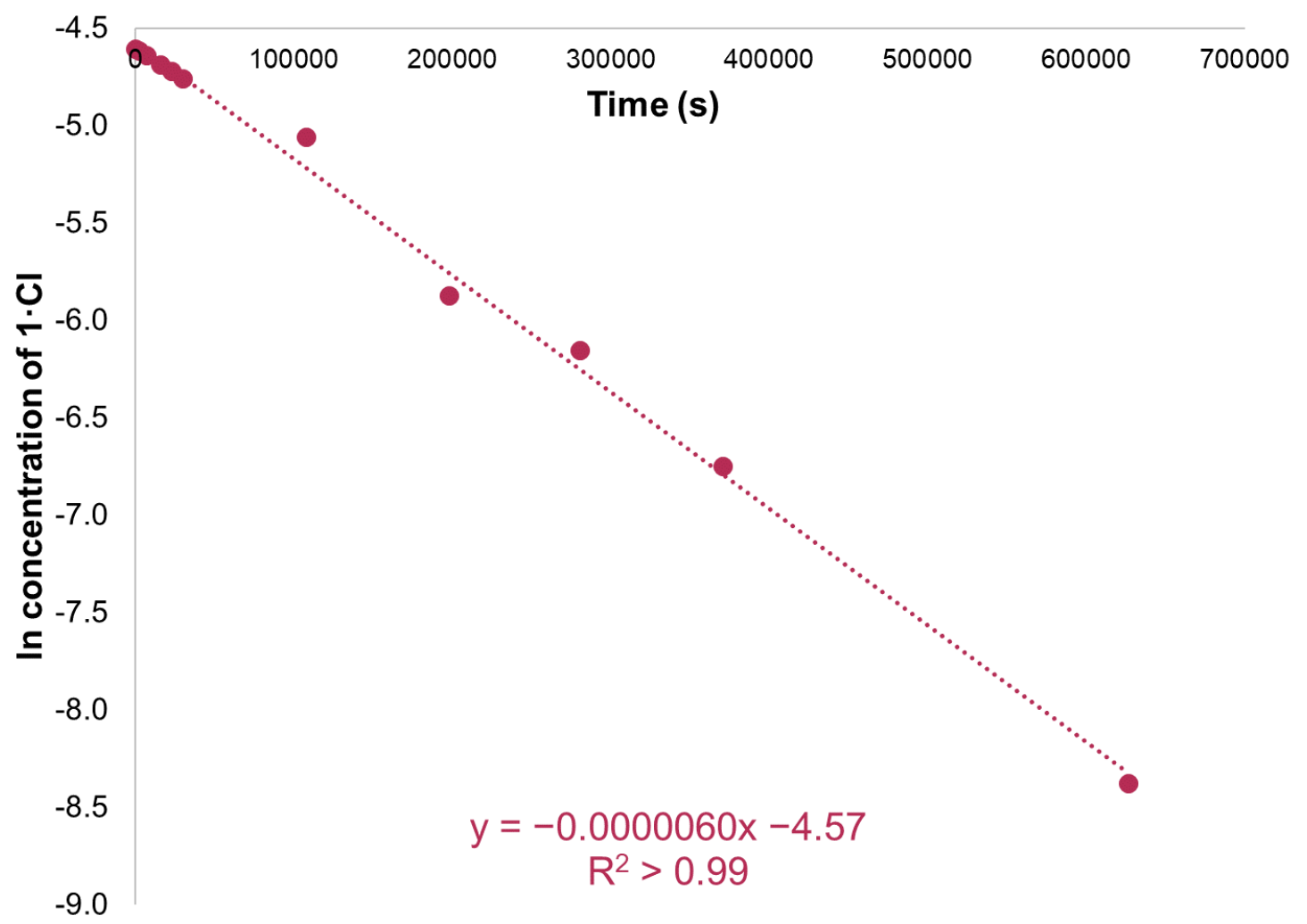

Figure S23. Conversion of 1. $\mathbf{C l}$ to benzamide over time at $\mathrm{pH} 12(10 \mathrm{mM}$ in $100 \mathrm{mM}$ aqueous phosphate buffer, room temperature).

Slope: $-6.0 \times 10^{-6}$

Estimated standard error of regression of slope: $1.2 \times 10^{-7}$

Intercept: -4.57

Estimated standard error of regression of intercept: 0.030

$\mathbf{R}^{2}: 0.996$ 
Hydrolysis of $1 \cdot \mathrm{Cl}$ in $100 \mathrm{mM} \mathrm{NaOH}(a q)$

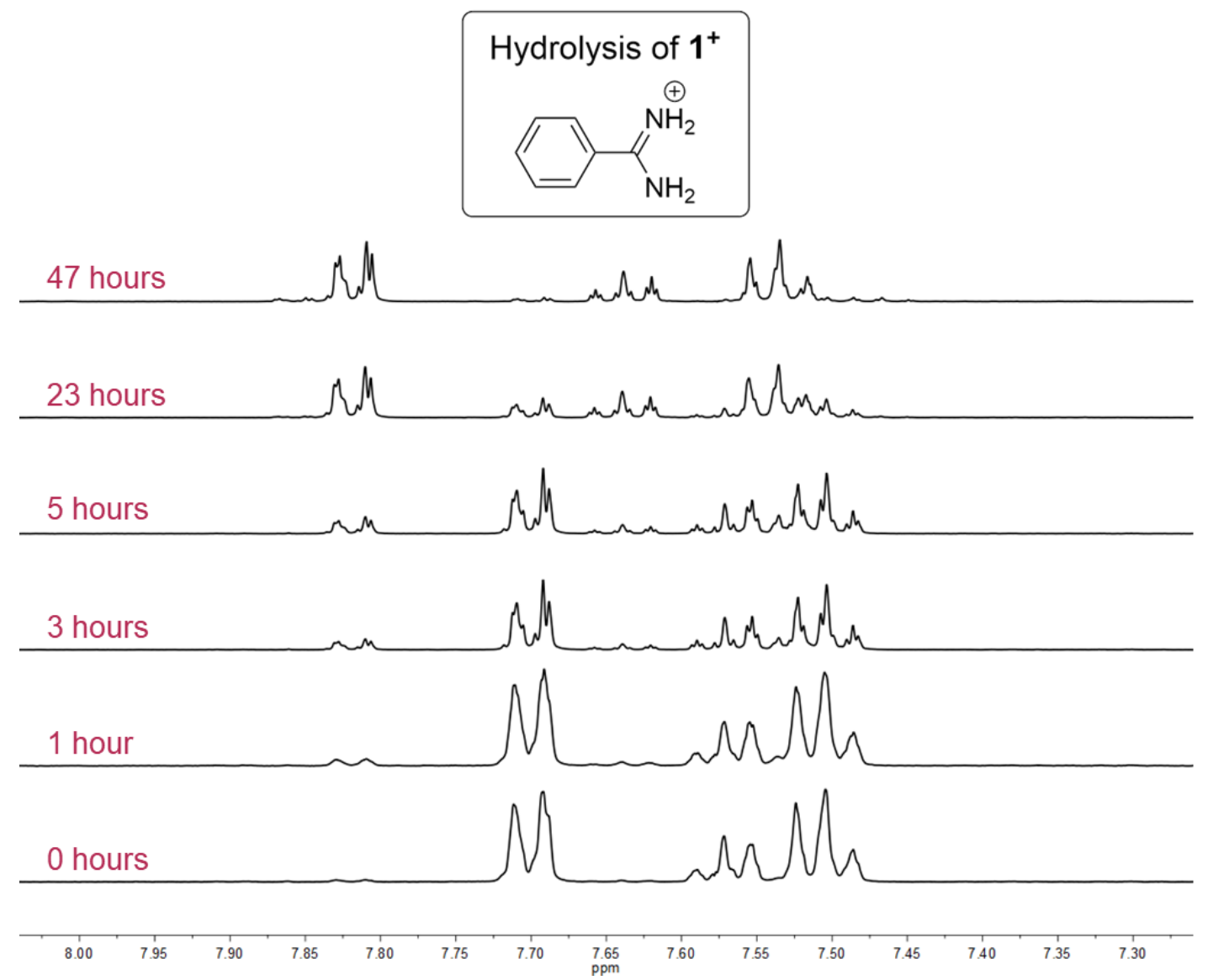

Figure S24. Truncated ${ }^{1} \mathrm{H}$ NMR spectra of $\mathbf{1} \cdot \mathbf{C l}$ at various timepoints in $100 \mathrm{mM} \mathrm{NaOH}(10 \mathrm{mM}$ with $100 \mathrm{mM} \mathrm{NaOH}$, room temperature, $400 \mathrm{MHz}$, $\mathrm{D}_{2} \mathrm{O}$ ). Additional minor peaks visible in the 47 hours spectrum result from subsequent hydrolysis of initially formed benzamide to benzoate.

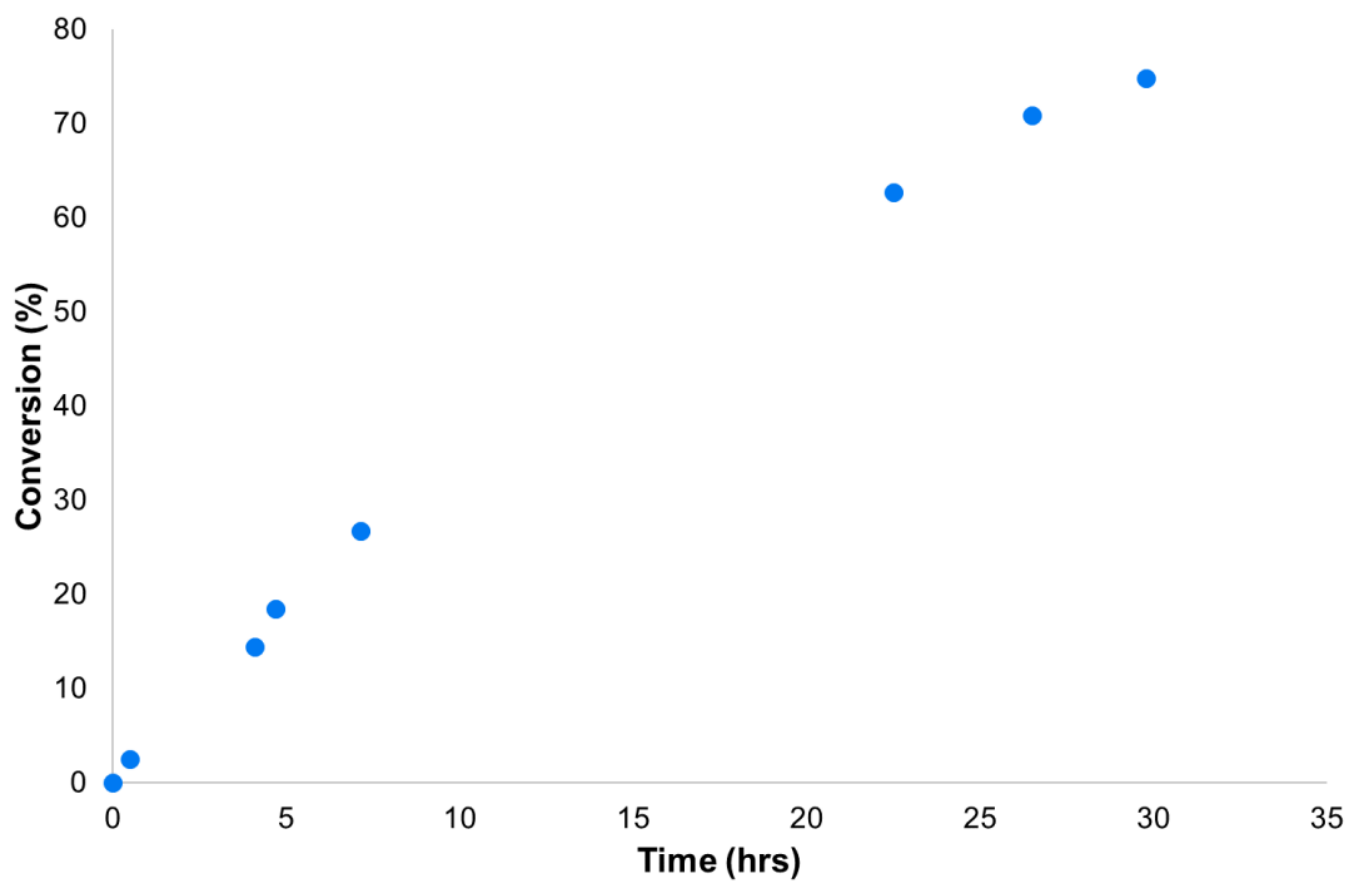

Figure S25. Conversion of $\mathbf{1 \cdot C l}$ to benzamide over time in $100 \mathrm{mM} \mathrm{NaOH}(10 \mathrm{mM}$ in $100 \mathrm{mM} \mathrm{NaOH}$, room temperature). 


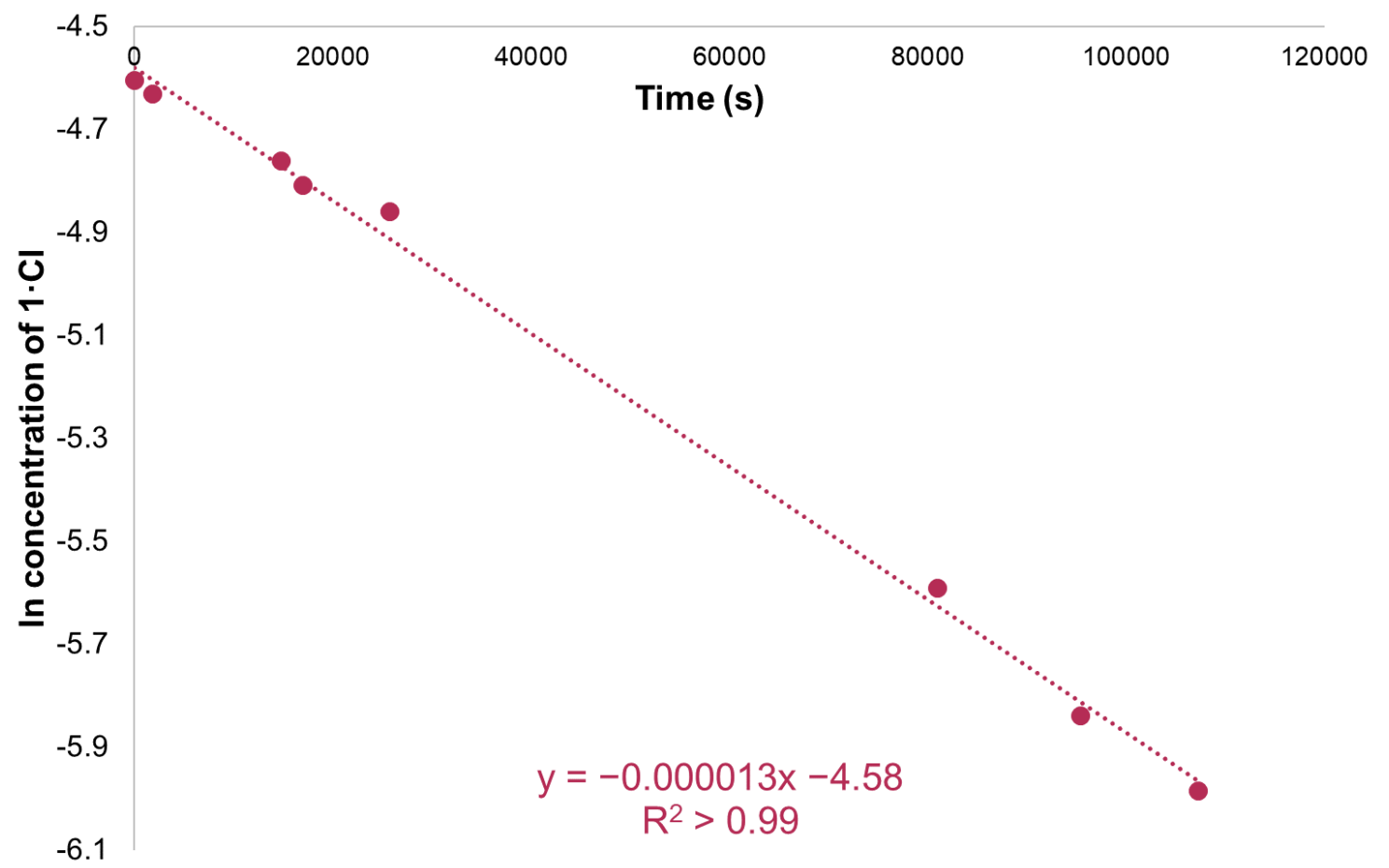

Figure S26. Conversion of $\mathbf{1 \cdot C l}$ to benzamide over time in $100 \mathrm{mM} \mathrm{NaOH}(10 \mathrm{mM}$ in $100 \mathrm{mM} \mathrm{NaOH}$, room temperature).

Slope: $-1.3 \times 10^{-5}$

Estimated standard error of regression of slope: $2.9 \times 10^{-7}$

Intercept: -4.58

Estimated standard error of regression of intercept: 0.017

$\mathbf{R}^{2}: 0.997$ 
Hydrolysis of $1 \cdot \mathrm{Cl}$ in $1.0 \mathrm{M} \mathrm{NaOH}_{(a q)}$

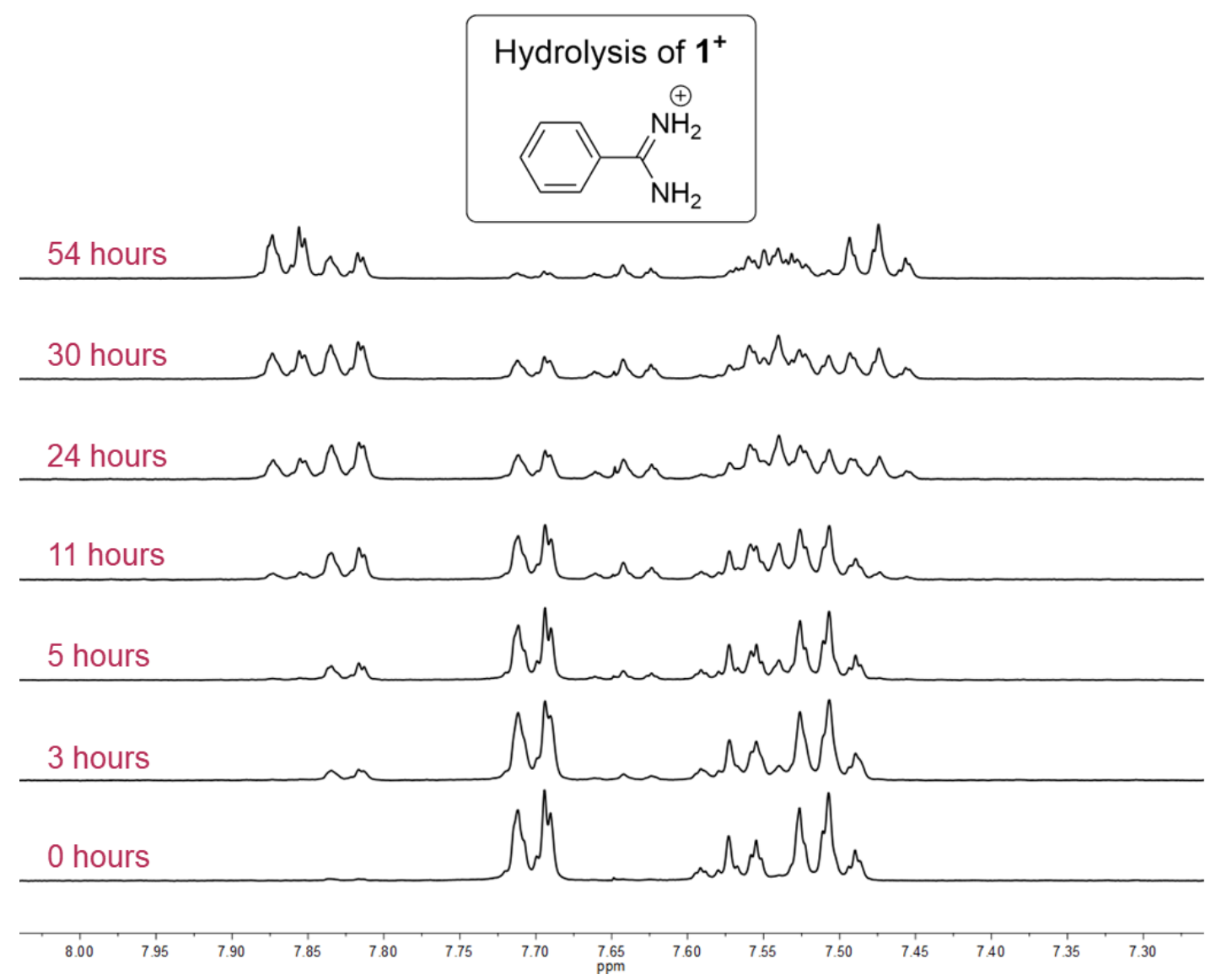

Figure S27. Truncated ${ }^{1} \mathrm{H}$ NMR spectra of $\mathbf{1} \cdot \mathbf{C l}$ at various timepoints in $1.0 \mathrm{M} \mathrm{NaOH}(10 \mathrm{mM}$ with $1.0 \mathrm{M} \mathrm{NaOH}$, room temperature, $400 \mathrm{MHz}$, $\mathrm{D}_{2} \mathrm{O}$ ). Additional minor peaks visible in the 54 hours spectrum result from subsequent hydrolysis of initially formed benzamide to benzoate.

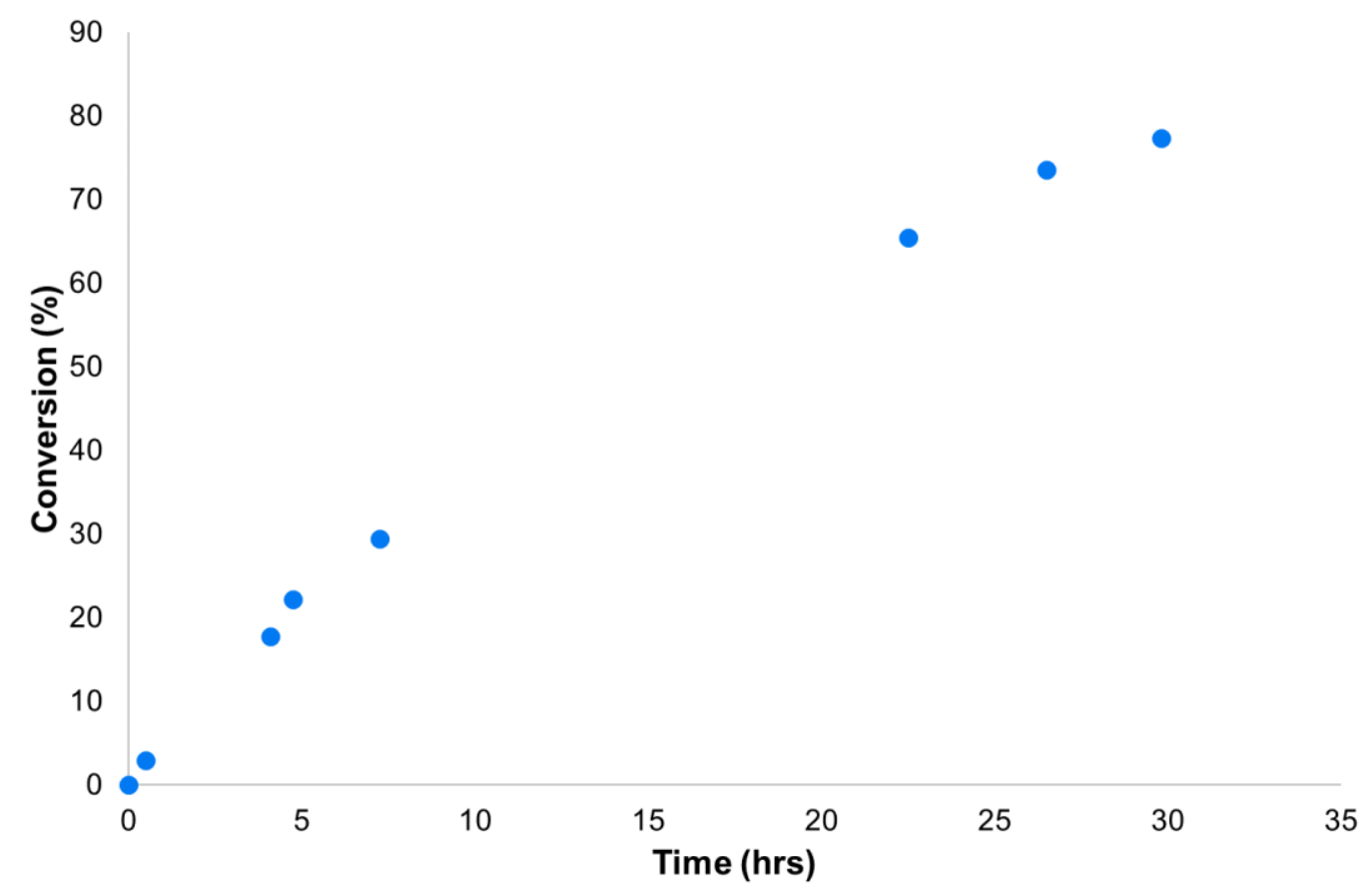

Figure S28. Conversion of $\mathbf{1} \cdot \mathbf{C l}$ to benzamide over time in $1.0 \mathrm{M} \mathrm{NaOH}(10 \mathrm{mM}$ in $1.0 \mathrm{M} \mathrm{NaOH}$, room temperature). 


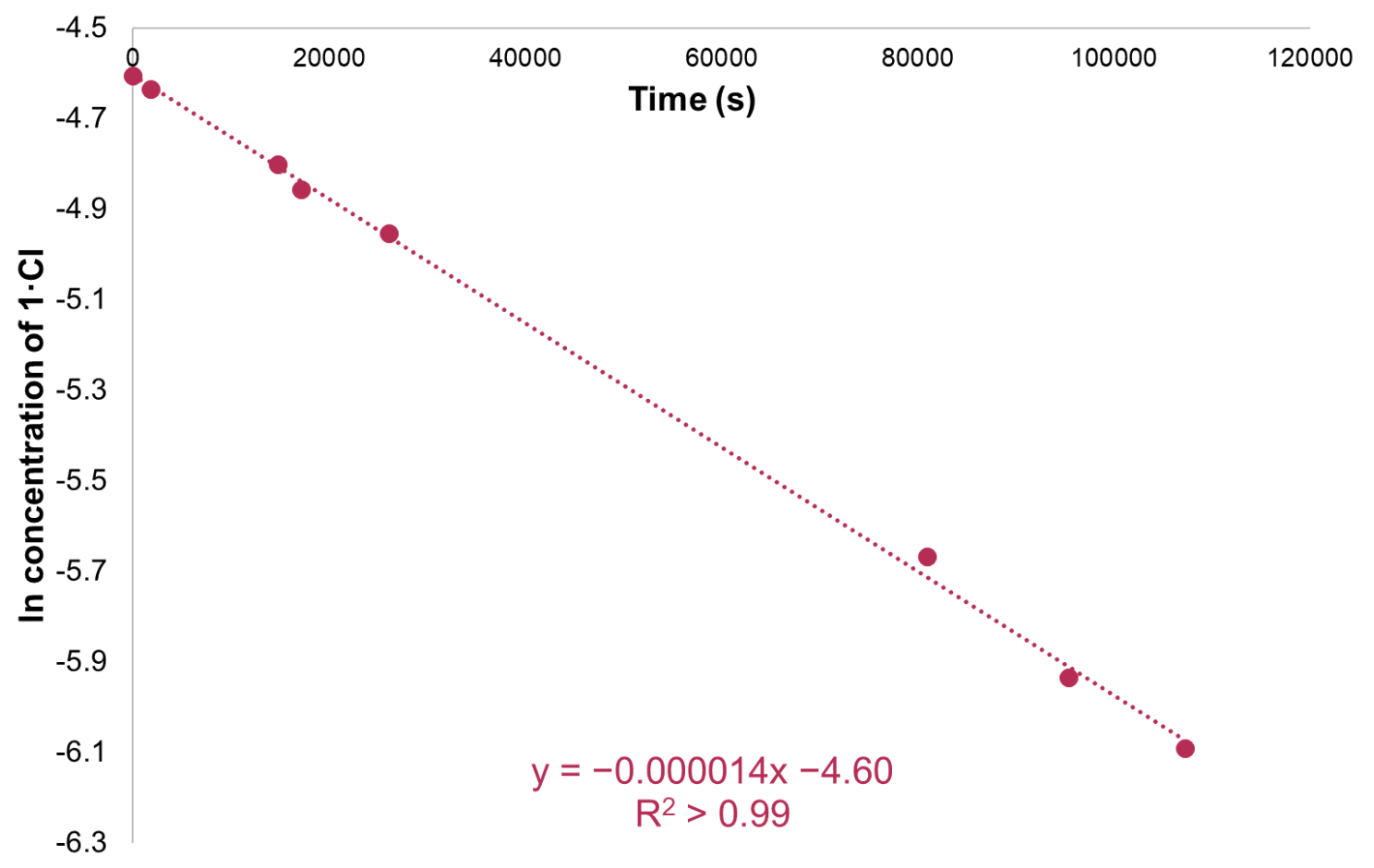

Figure S29. Conversion of $\mathbf{1} \cdot \mathbf{C l}$ to benzamide over time in $1.0 \mathrm{M} \mathrm{NaOH}(10 \mathrm{mM}$ in $1.0 \mathrm{M} \mathrm{NaOH}$, room temperature).

Slope: $-1.4 \times 10^{-5}$

Estimated standard error of regression of slope: $2.1 \times 10^{-7}$

Intercept: -4.60

Estimated standard error of regression of intercept: 0.012

$\mathbf{R}^{2}: 0.999$ 


\section{Hydrolysis of $1 \cdot \mathrm{Cl}$ in $1 \% \mathrm{NH}_{3}(\mathrm{aq})$}

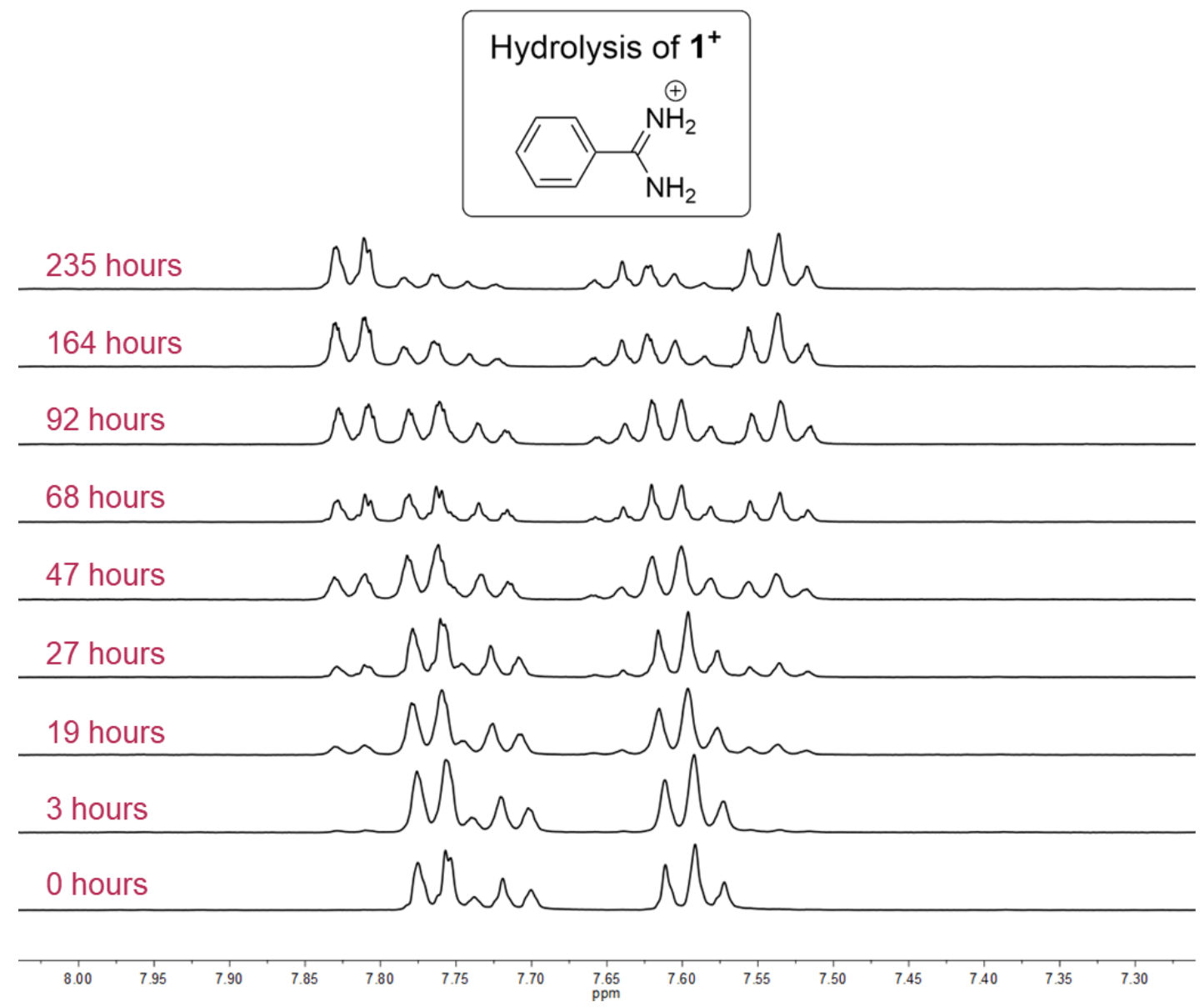

Figure S30. Truncated ${ }^{1} \mathrm{H}$ NMR spectra of $1 \cdot \mathrm{Cl}$ at various timepoints in $1 \% \mathrm{NH}_{3(\mathrm{aq})}\left(10 \mathrm{mM}\right.$, room temperature, $\left.400 \mathrm{MHz}, \mathrm{D}_{2} \mathrm{O}\right)$.

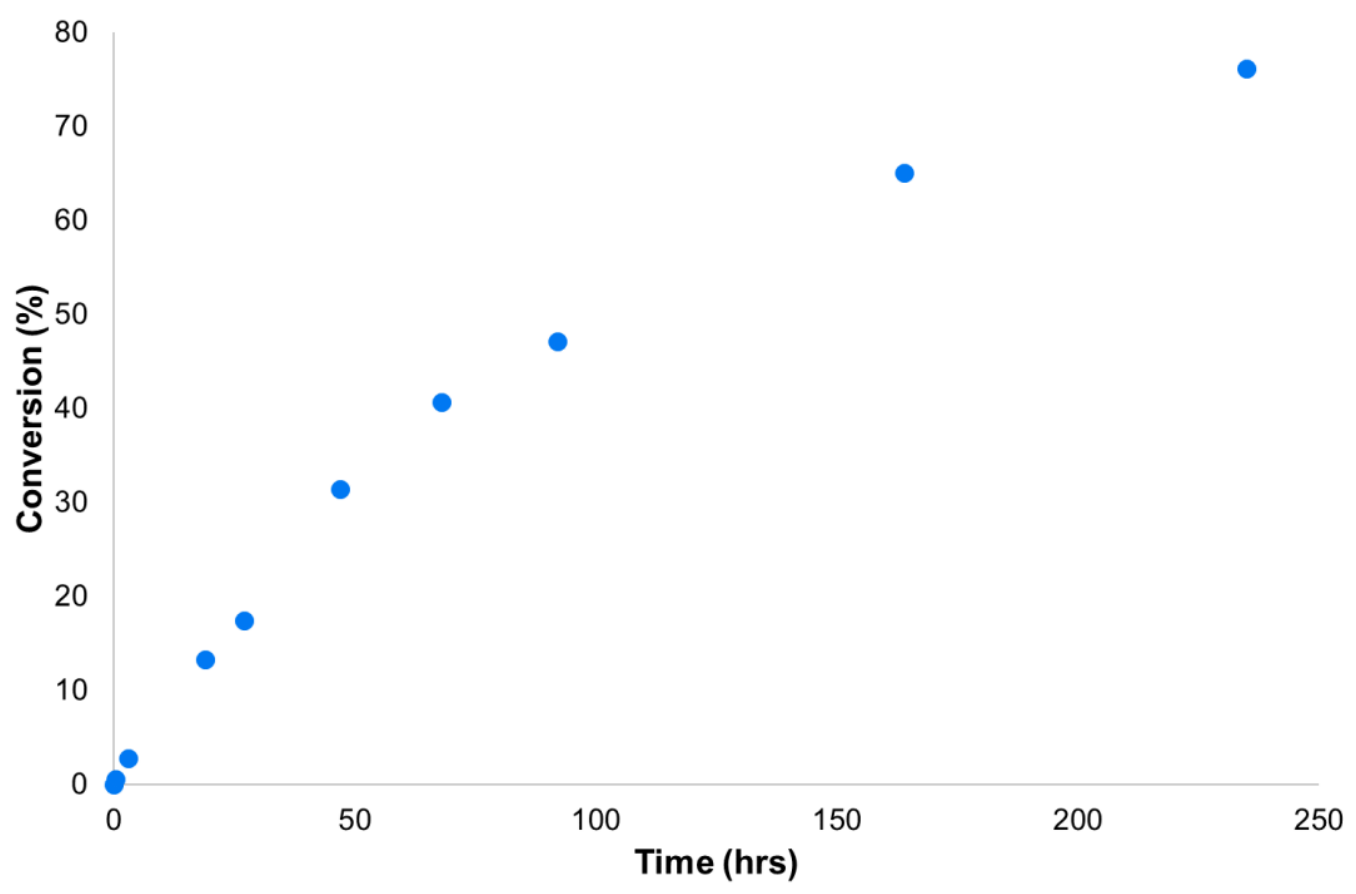

Figure S31. Conversion of $\mathbf{1} \cdot \mathbf{C l}$ to benzamide over time in $1 \% \mathrm{NH}_{3(\mathrm{aq})}(10 \mathrm{mM}$, room temperature). 


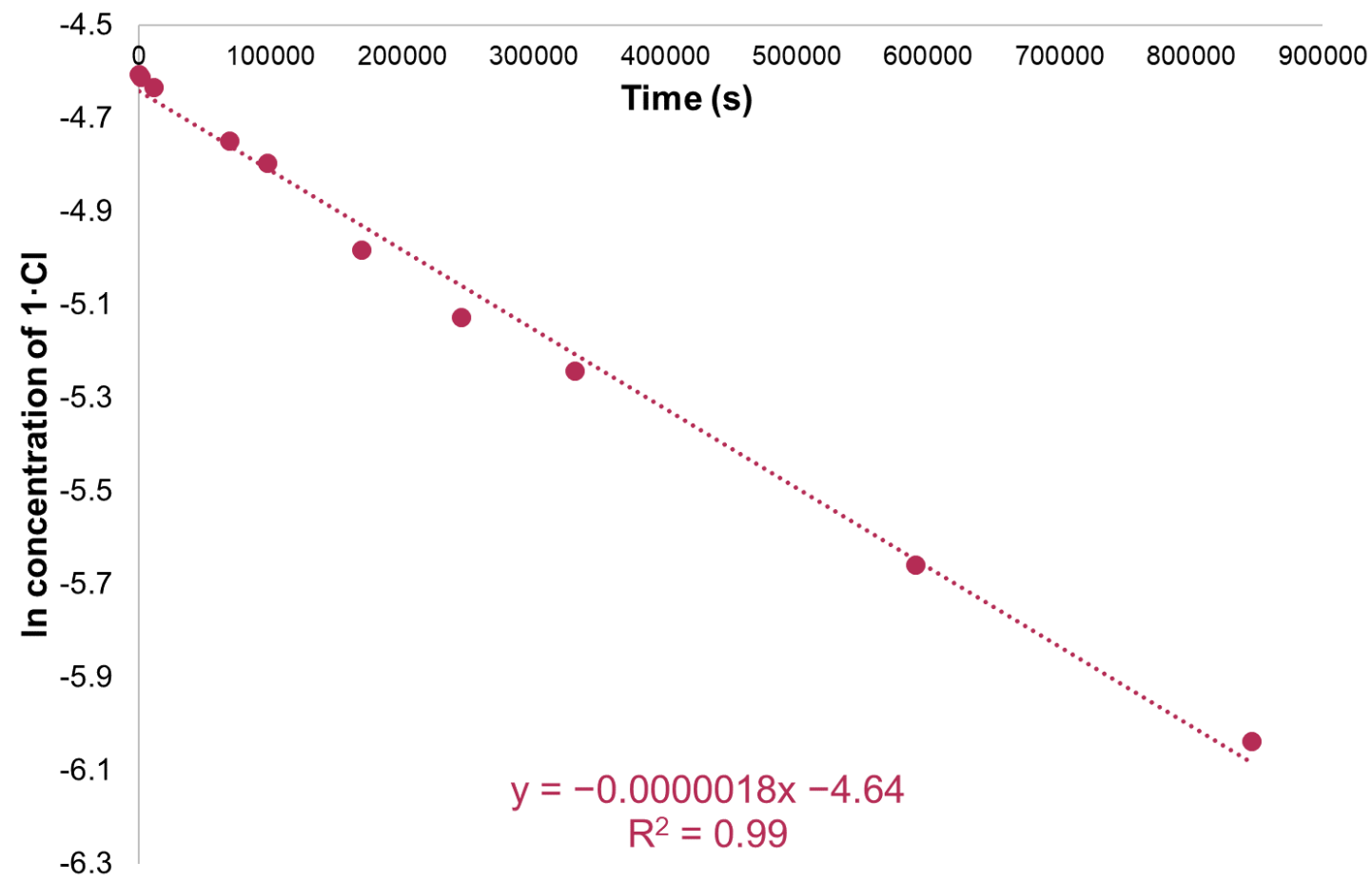

Figure S32. Conversion of $\mathbf{1 \cdot} \mathbf{C l}$ to benzamide over time in $1 \% \mathrm{NH}_{3(\mathrm{aq})}(10 \mathrm{mM})$.

Slope: $-1.7 \times 10^{-6}$

Estimated standard error of regression of slope: $5.0 \times 10^{-8}$

Intercept: -4.64

Estimated standard error of regression of intercept: 0.018

$\mathbf{R}^{2}: 0.993$ 


\section{Hydrolysis of $2 \cdot \mathrm{Cl}_{4}$ in $1 \% \mathrm{NH}_{3}(a q)$}

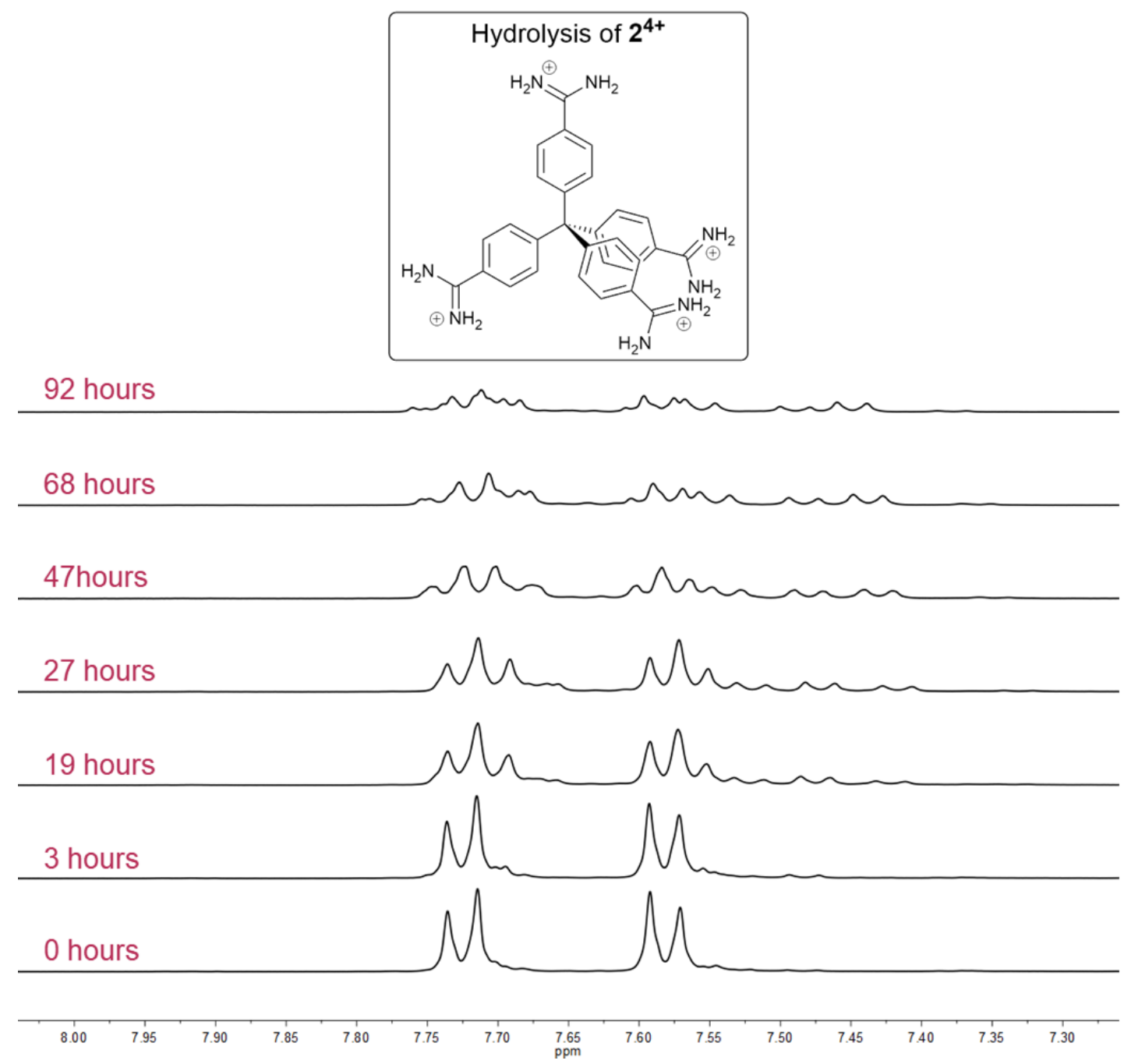

Figure S33. Truncated ${ }^{1} \mathrm{H}$ NMR spectra of 2. $\mathrm{Cl}_{4}$ at various timepoints in $1 \% \mathrm{NH}_{3(\mathrm{aq})}\left(10 \mathrm{mM}\right.$, room temperature, $\left.400 \mathrm{MHz}, \mathrm{D}_{2} \mathrm{O}\right)$. Note: the product of this hydrolysis precipitates.

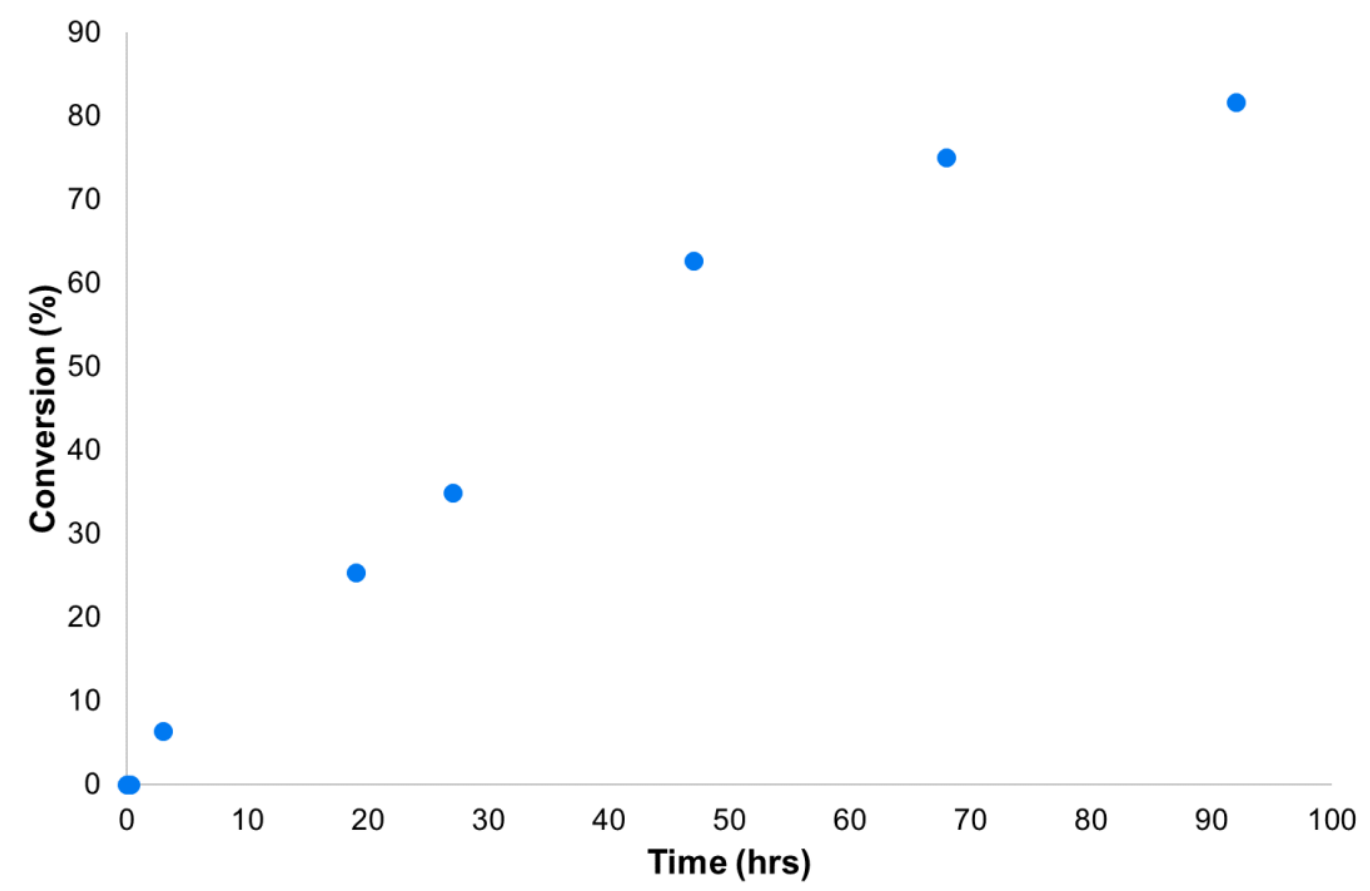

Figure S34. Conversion of $\mathbf{2} \cdot \mathbf{C l}_{4}$ to $\mathbf{4}$ over time in $1 \% \mathrm{NH}_{3(\mathrm{aq})}(10 \mathrm{mM}$, room temperature). 


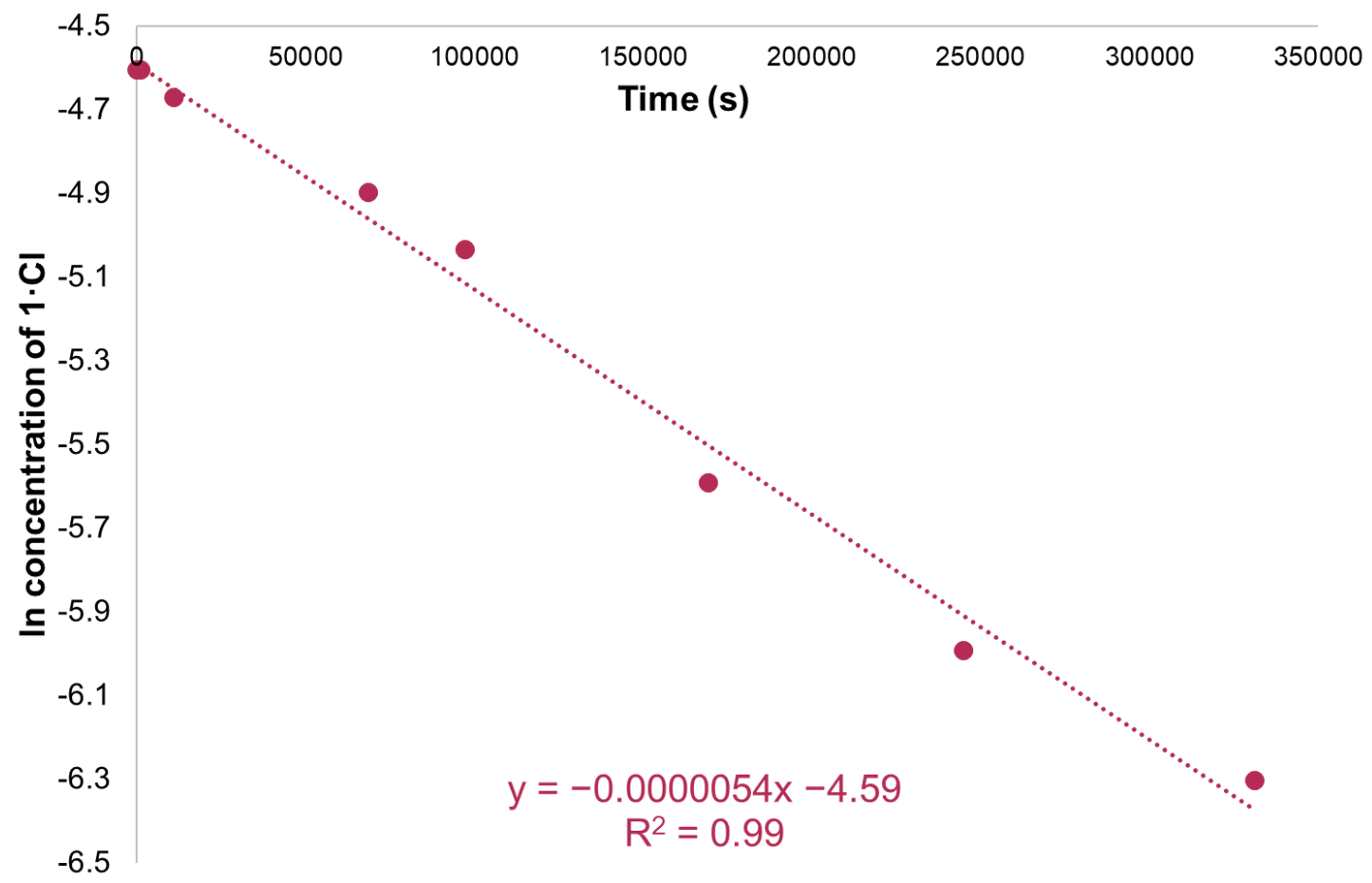

Figure S35. Conversion of $\mathbf{2} \cdot \mathbf{C l}_{4}$ to $\mathbf{4}$ over time in $1 \% \mathrm{NH}_{3(\mathrm{aq})}(10 \mathrm{mM})$.

Slope: $-5.4 \times 10^{-6}$

Estimated standard error of regression of slope: $2.2 \times 10^{-7}$

Intercept: -4.59

Estimated standard error of regression of intercept: 0.036

$\mathbf{R}^{2}: 0.990$ 


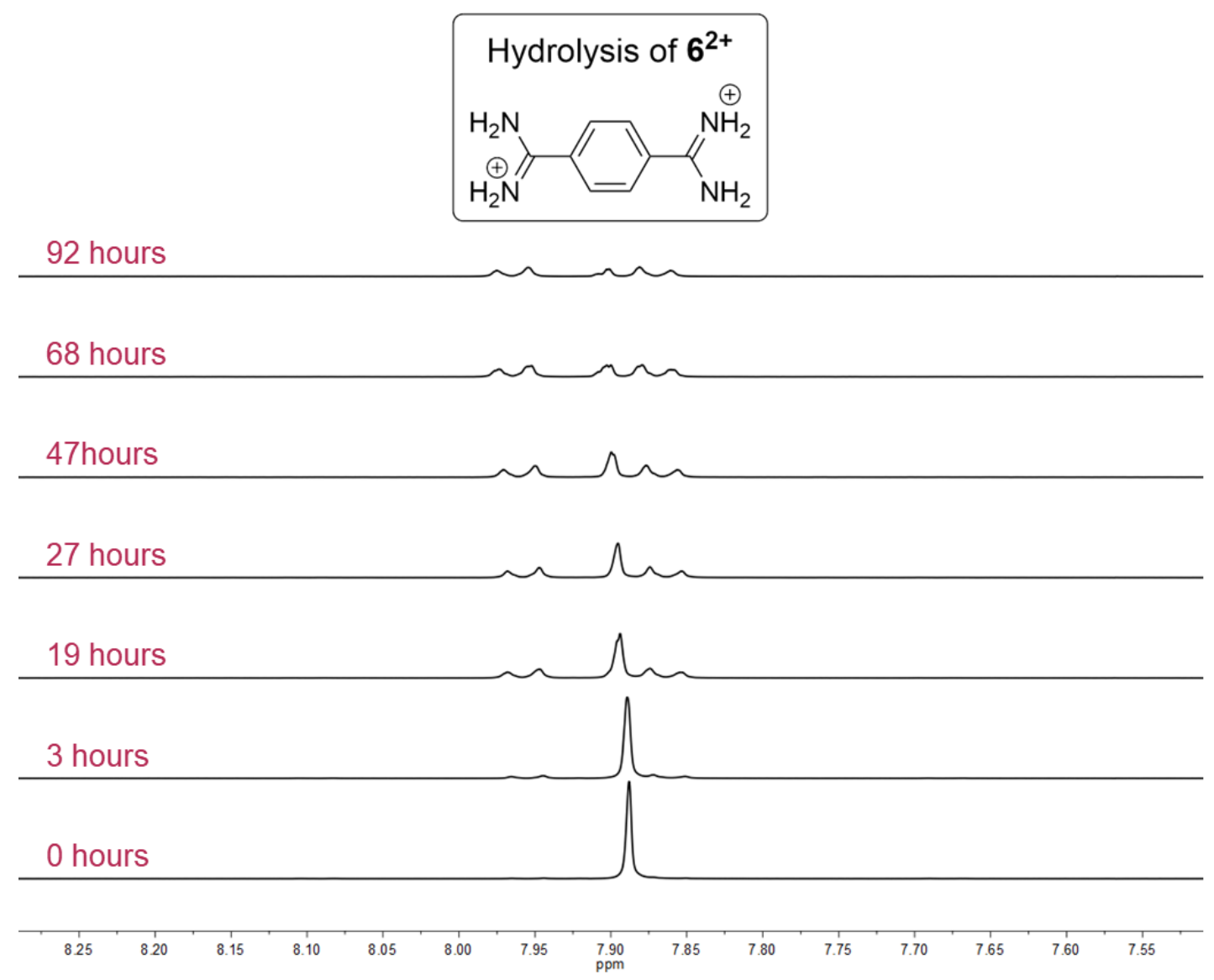

Figure S36. Truncated ${ }^{1} \mathrm{H}$ NMR spectra of $6 \cdot \mathrm{Cl}_{2}$ at various timepoints in $1 \% \mathrm{NH}_{3(\mathrm{aq})}\left(10 \mathrm{mM}\right.$, room temperature, $\left.400 \mathrm{MHz}, \mathrm{D}_{2} \mathrm{O}\right)$. Note: the product of this hydrolysis (terepthalamide) precipitates.

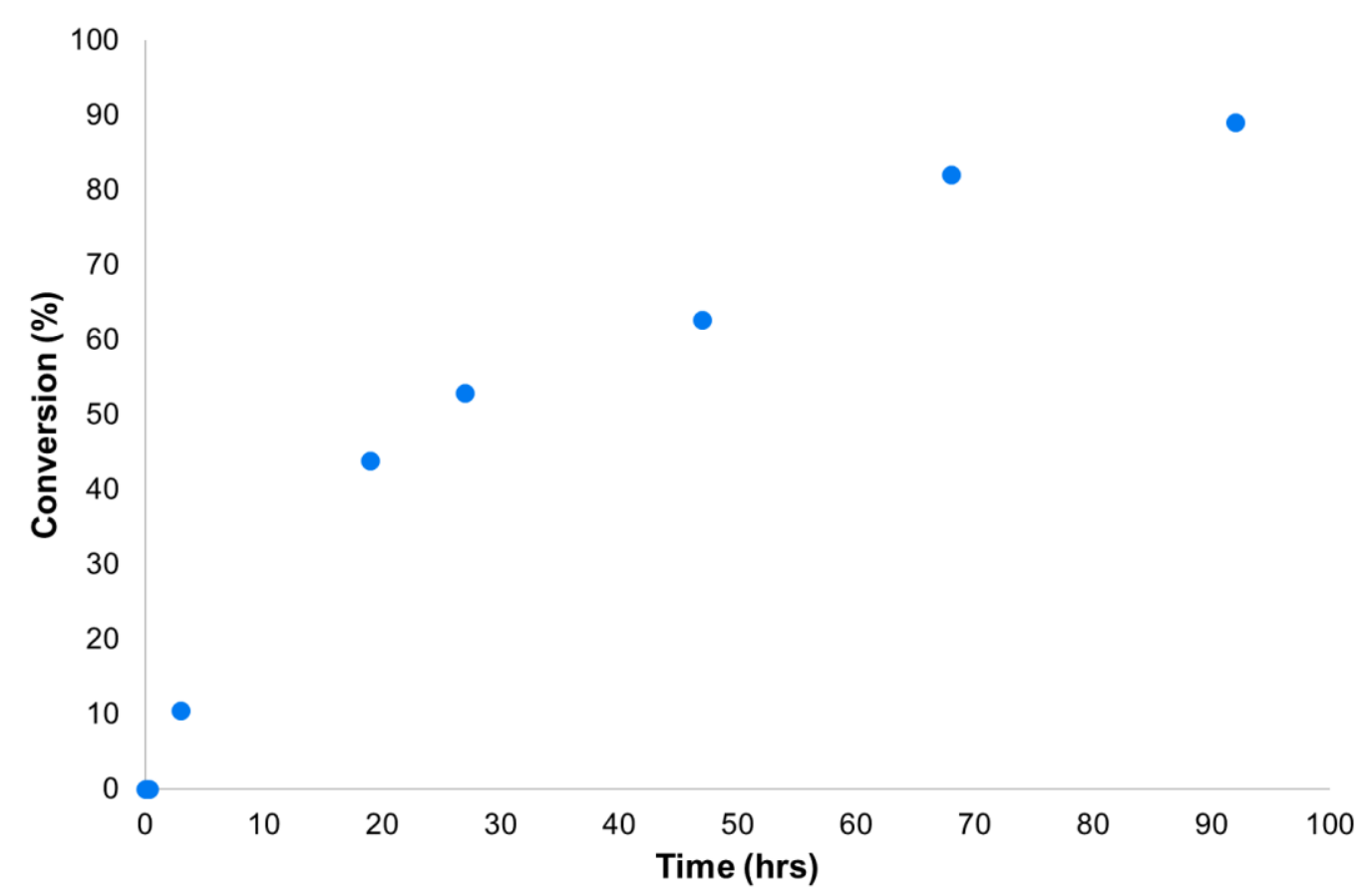

Figure S37. Conversion of $\mathbf{6} \cdot \mathbf{C l}_{2}$ to terephthalamide over time in $1 \% \mathrm{NH}_{3(\mathrm{aq})}(10 \mathrm{mM}$, room temperature). 


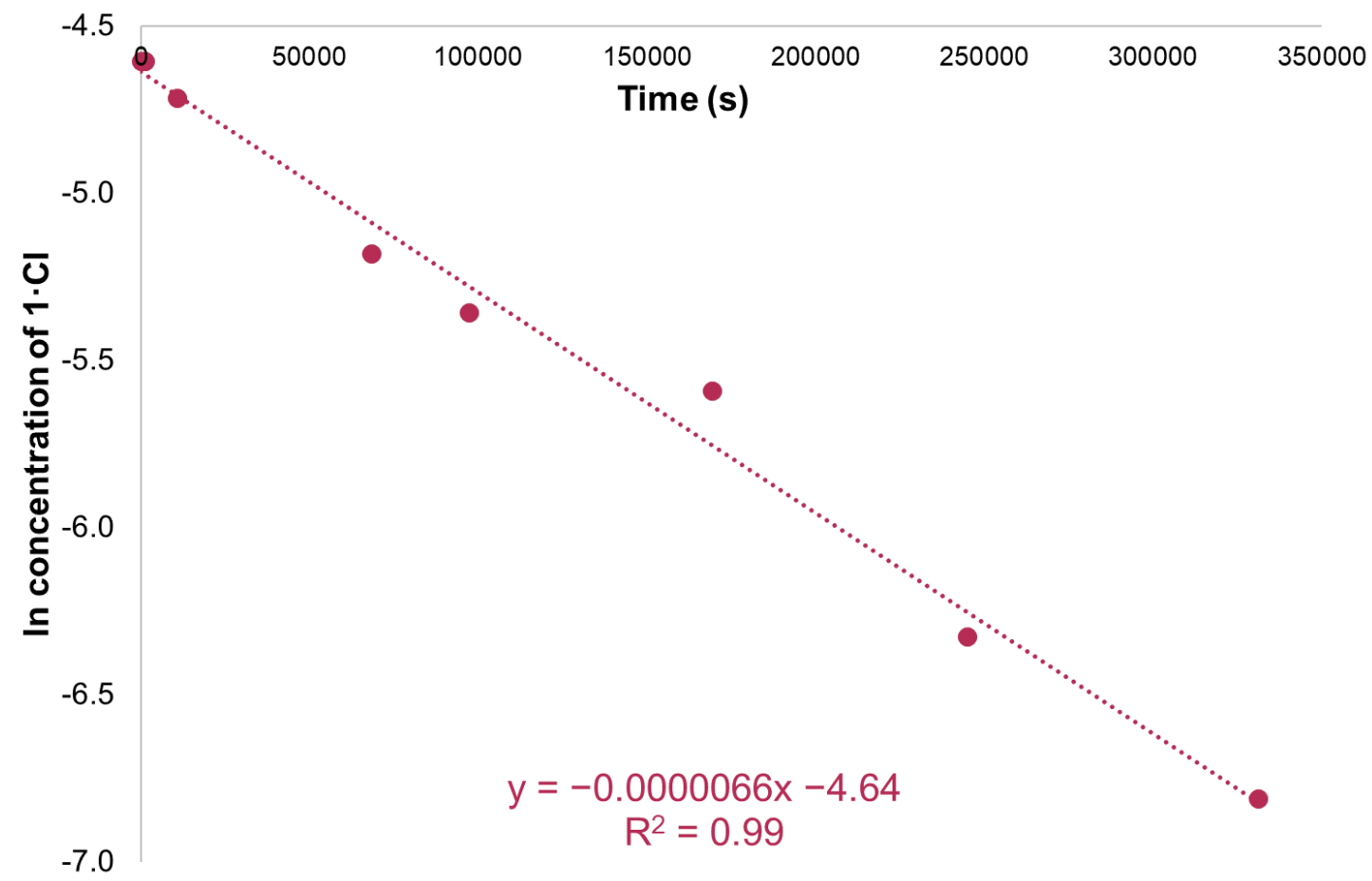

Figure S38. Conversion of $\mathbf{6} \cdot \mathbf{C l}_{2}$ to terephthalamide over time in $1 \% \mathrm{NH}_{3(\mathrm{aq})}(10 \mathrm{mM})$.

Slope: $-6.6 \times 10^{-6}$

Estimated standard error of regression of slope: $2.8 \times 10^{-7}$

Intercept: -4.64

Estimated standard error of regression of intercept: 0.045

$\mathbf{R}^{2}: 0.989$ 


\section{Hydrolysis of H-bonded frameworks}

The structures of the hydrogen bonded frameworks are shown in Figure S39. The synthesis and X-ray crystal structures of these frameworks have been published previously. Framework of $\mathbf{2}^{4+}$ and tetrakis(4-carboxyphenyl)methane dodecahydrate, CSD: 1902514 ;9 $^{\text {framework }}$ of $6^{2+}$ and terephthalate, CSDs: 1537445 for X-ray crystal structure at $150 \mathrm{~K}, \mathrm{S10} 2047427$ for X-ray crystal structure at $293 \mathrm{~K} . \mathrm{s} 11$

The frameworks were suspended in $1 \% \mathrm{NH}_{3}$ in $\mathrm{D}_{2} \mathrm{O}$ at a concentration of $10 \mathrm{mM}$ for 7 days. During this time, the liquid phase was monitored by ${ }^{1} \mathrm{H}$ NMR spectroscopy, which indicated negligible leaching into solution (the carboxylate components of each framework are highly water soluble, so framework breakdown due to hydrolysis of the amidinium component would be expected to leach carboxylate into solution). After 7 days, the suspensions were filtered, the resulting solids were both washed with $2 \times 0.5 \mathrm{~mL} \mathrm{H} \mathrm{H}_{2}$, and then thoroughly air-dried. After this time, a part of the sample was dissolved in $\mathrm{d}_{6}$-DMSO containing a drop of conc. $\mathrm{DCl}_{(\mathrm{aq})}$ and analysed by ${ }^{1} \mathrm{H}$ NMR spectroscopy, while a part was analysed by powder X-ray diffraction.
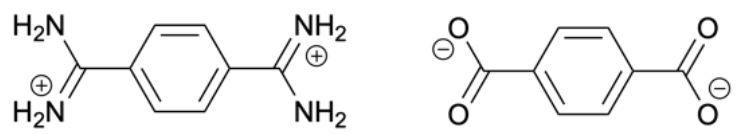

Hydrogen bonded framework formed from $6^{2+}$ and terephthalate

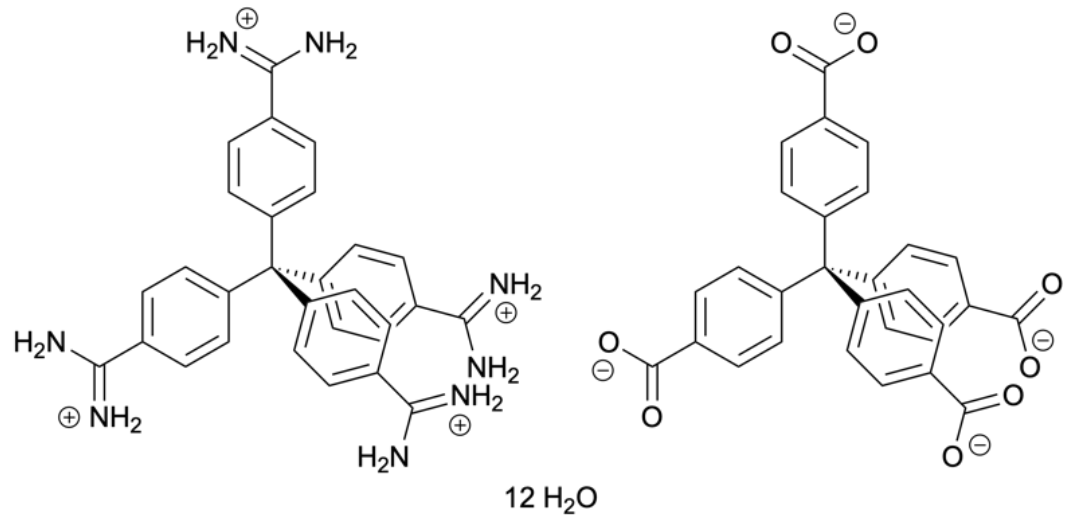

Hydrogen bonded framework formed from $2^{4+}$ and tetrakis(4-carboxyphenyl)methane

Figure S39. Chemical structures of hydrogen bonded frameworks studied in this work. 
${ }^{1} \mathrm{H}$ NMR spectroscopy: The ${ }^{1} \mathrm{H}$ NMR spectra of acid-digested frameworks are shown in Figure S40 and S41. No decomposition is observed in the spectrum of the framework prepared from $6^{2+}$, while very minor decomposition $(<5 \%)$ is observed in the spectrum of the framework prepared from $2^{4+}$. Amidinium $\mathrm{N}-\mathrm{H}$ peaks $(9.5-10 \mathrm{ppm})$ are much less intense than expected in both spectra due to $H / D$ exchange.

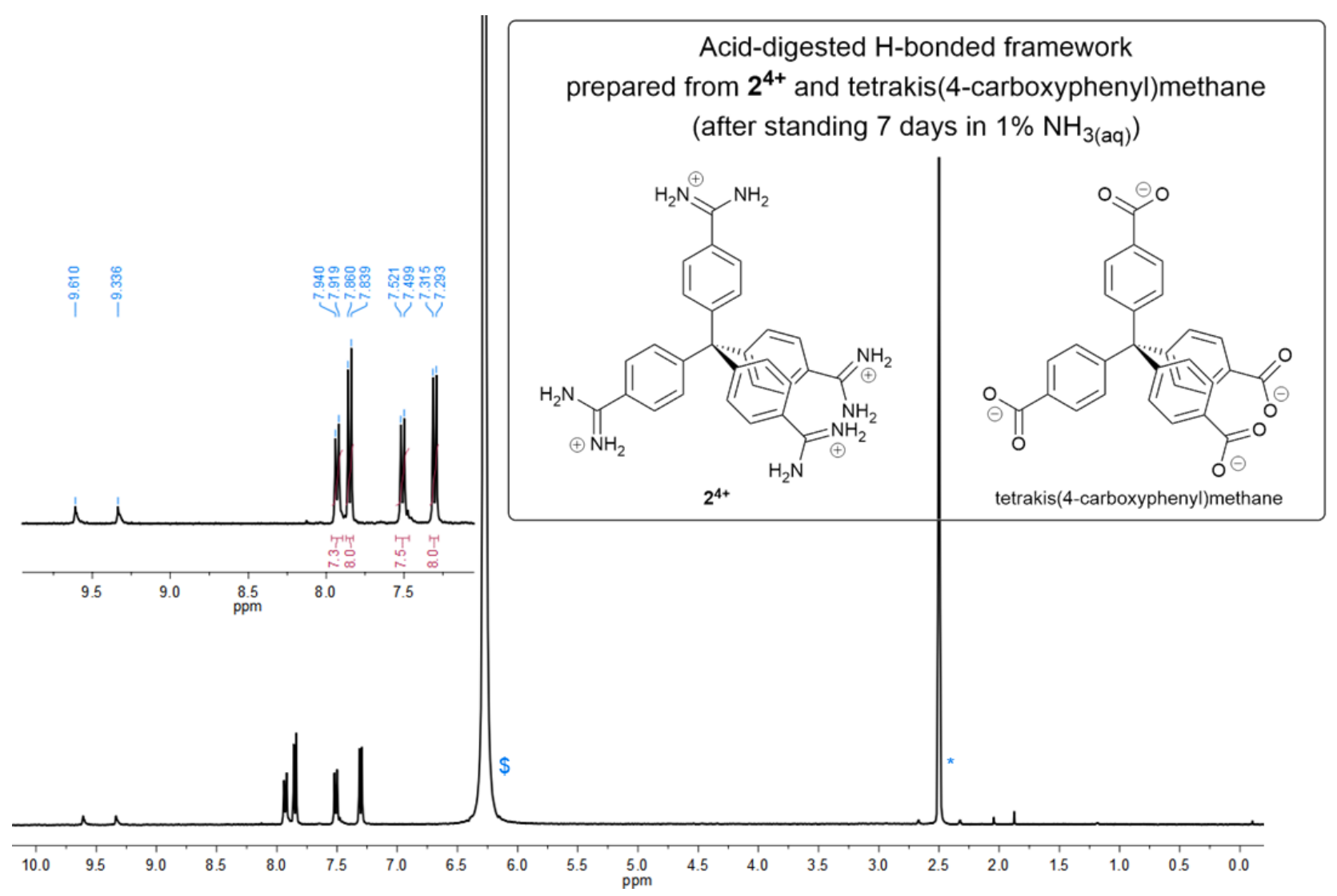

Figure S40. ${ }^{1} \mathrm{H}$ NMR spectrum of acid-digested framework prepared from $\mathbf{2}^{4+}$ and tetrakis(4-carboxyphenyl)methane; * represents $\mathrm{d}_{5}$-DMSO residual solvent peak, $\$$ represents water peak, which has been truncated $\left(400 \mathrm{MHz}, 298 \mathrm{~K}, \mathrm{~d}_{6}-\mathrm{DMSO}\right.$ containing a drop of $\mathrm{DCl}(\mathrm{aq})$ ).

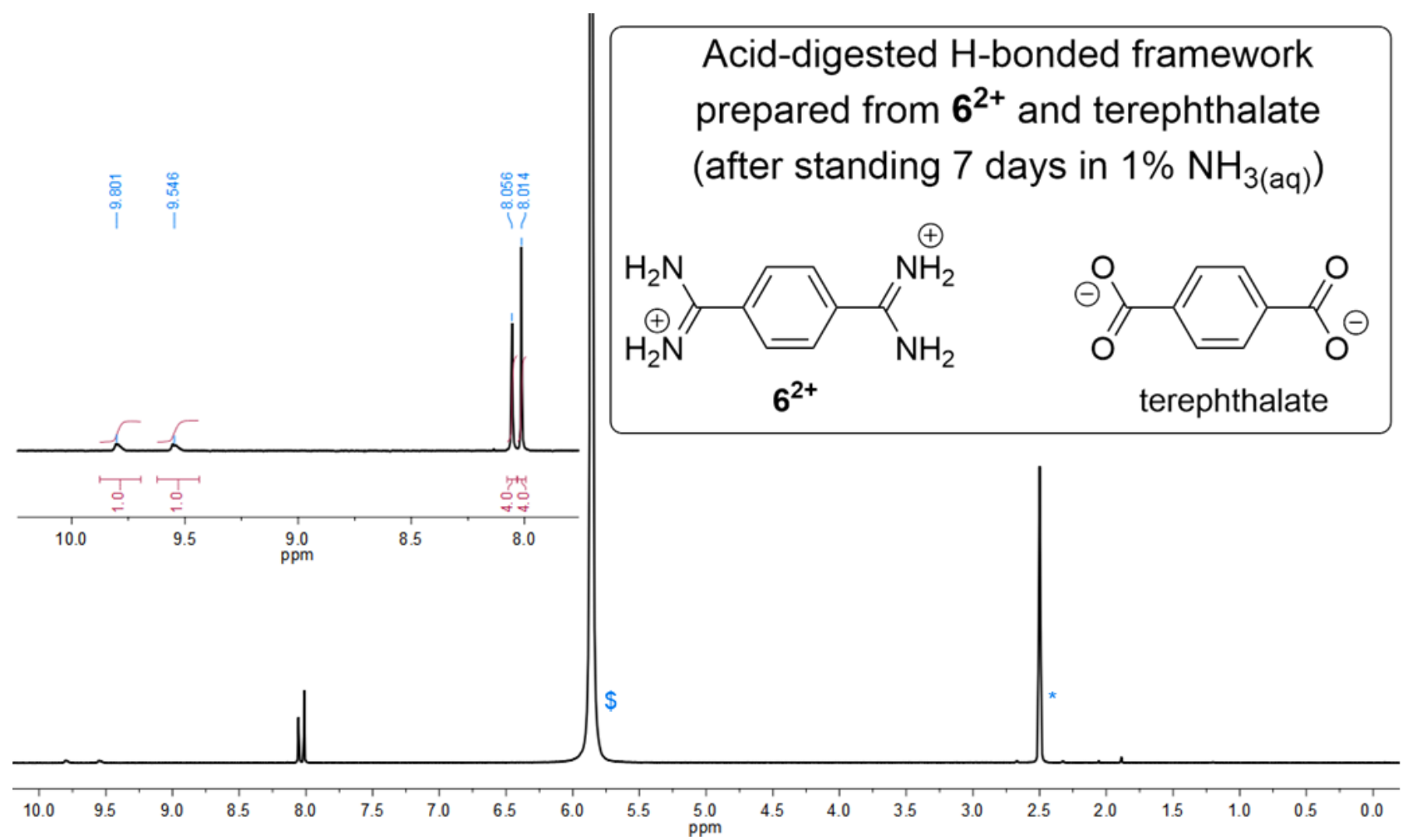

Figure S41. ${ }^{1} \mathrm{H}$ NMR spectrum of acid-digested framework prepared from $6^{2+}$ and terephthalate; * represents $\mathrm{d}_{5}$-DMSO residual solvent peak, $\$$ represents water peak, which has been truncated $\left(400 \mathrm{MHz}, 298 \mathrm{~K}, \mathrm{~d}_{6}\right.$-DMSO containing a drop of $\left.\mathrm{DCl}_{(\mathrm{aq})}\right)$. 
Powder X-ray diffraction (PXRD): PXRD traces of the two frameworks after one week in $1 \% \mathrm{NH}_{3}$ in $\mathrm{D}_{2} \mathrm{O}$ are shown in Figure S42 and S43. Both samples remain highly crystalline, and retain the structure present in the single crystals. These PXRD traces are essentially identical to samples that have not been treated with base. ${ }^{\mathrm{S9}, \mathrm{S10}}$

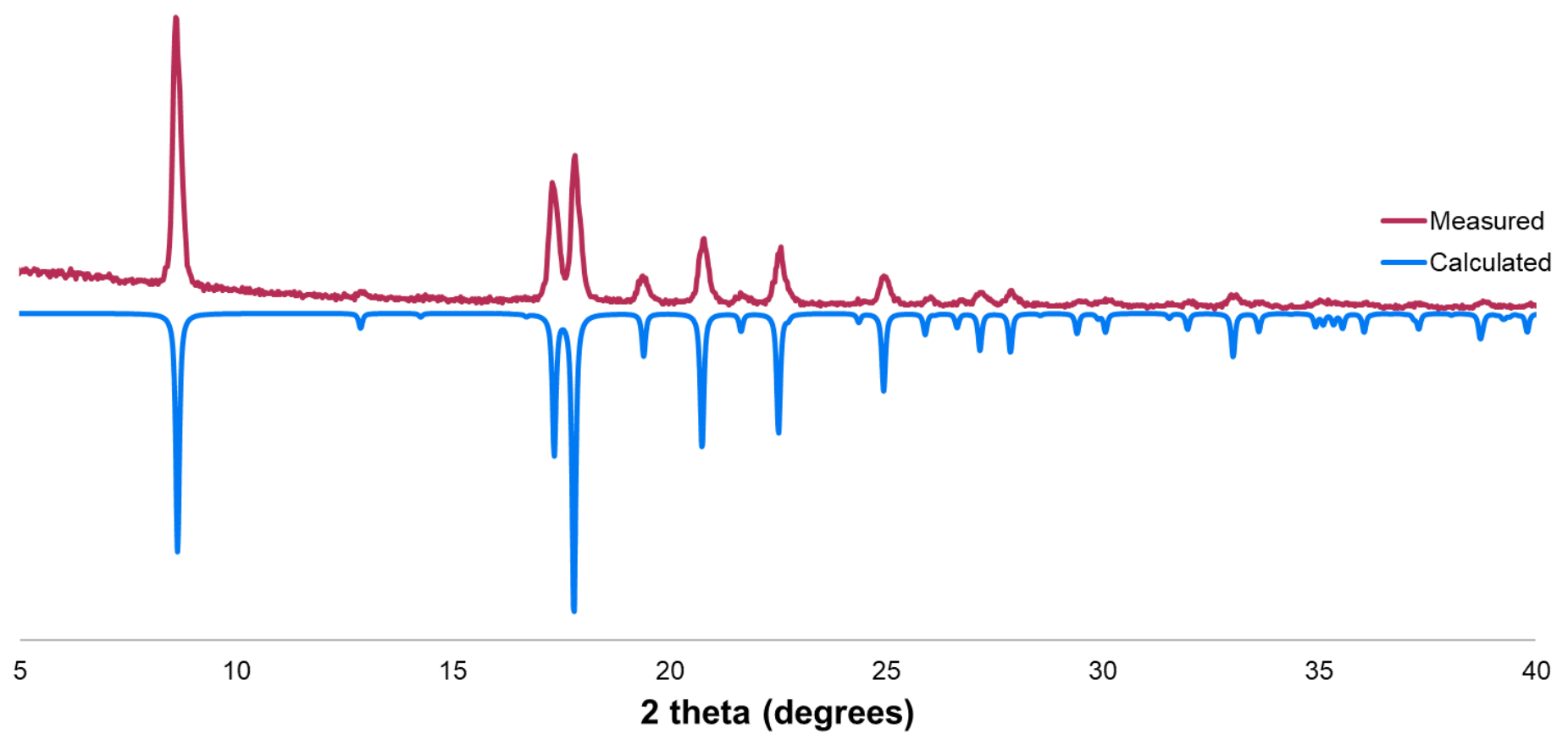

Figure S42. PXRD trace of the framework prepared from $\mathbf{2}^{4+}$ and tetrakis(4-carboxyphenyl)methane (recorded at room temperature, red, up), and comparison with that calculated based on the SCXRD structure of this compound ${ }^{\text {S9 }}$ (CSD: 1902514, recorded at $150 \mathrm{~K}$, blue, down).

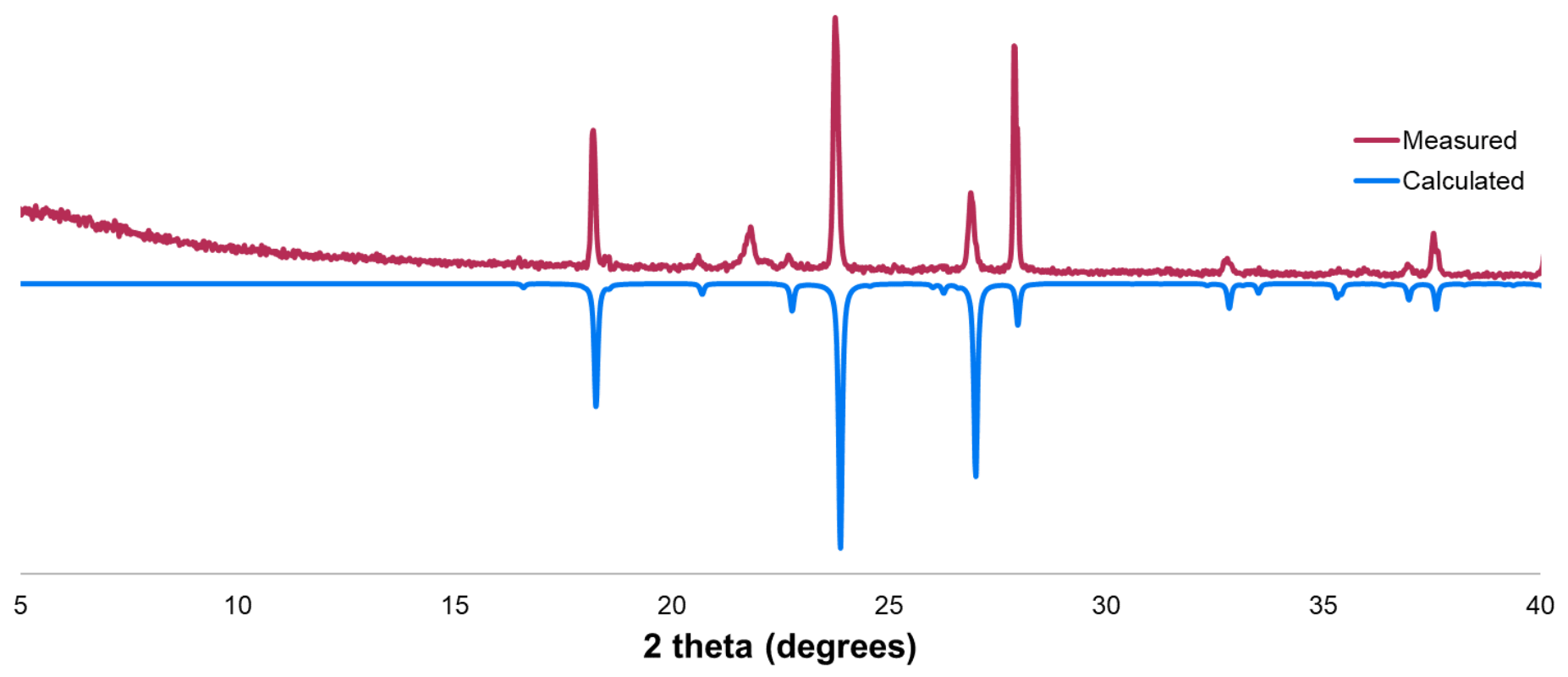

Figure S43. PXRD trace of the framework prepared from $6^{2+}$ and terephthalate (recorded at room temperature, red, up), and comparison with that calculated based on the SCXRD structure of this compound ${ }^{\text {111 }}$ (CSD: 2047427, recorded at room temperature, blue, down). 


\section{Computational studies}

\section{Complete reaction scheme}

The complete reaction scheme including all modelled species is shown in Scheme S1. Calculated energies for these reaction pathways, and calculated atomic coordinates are provided in this section.

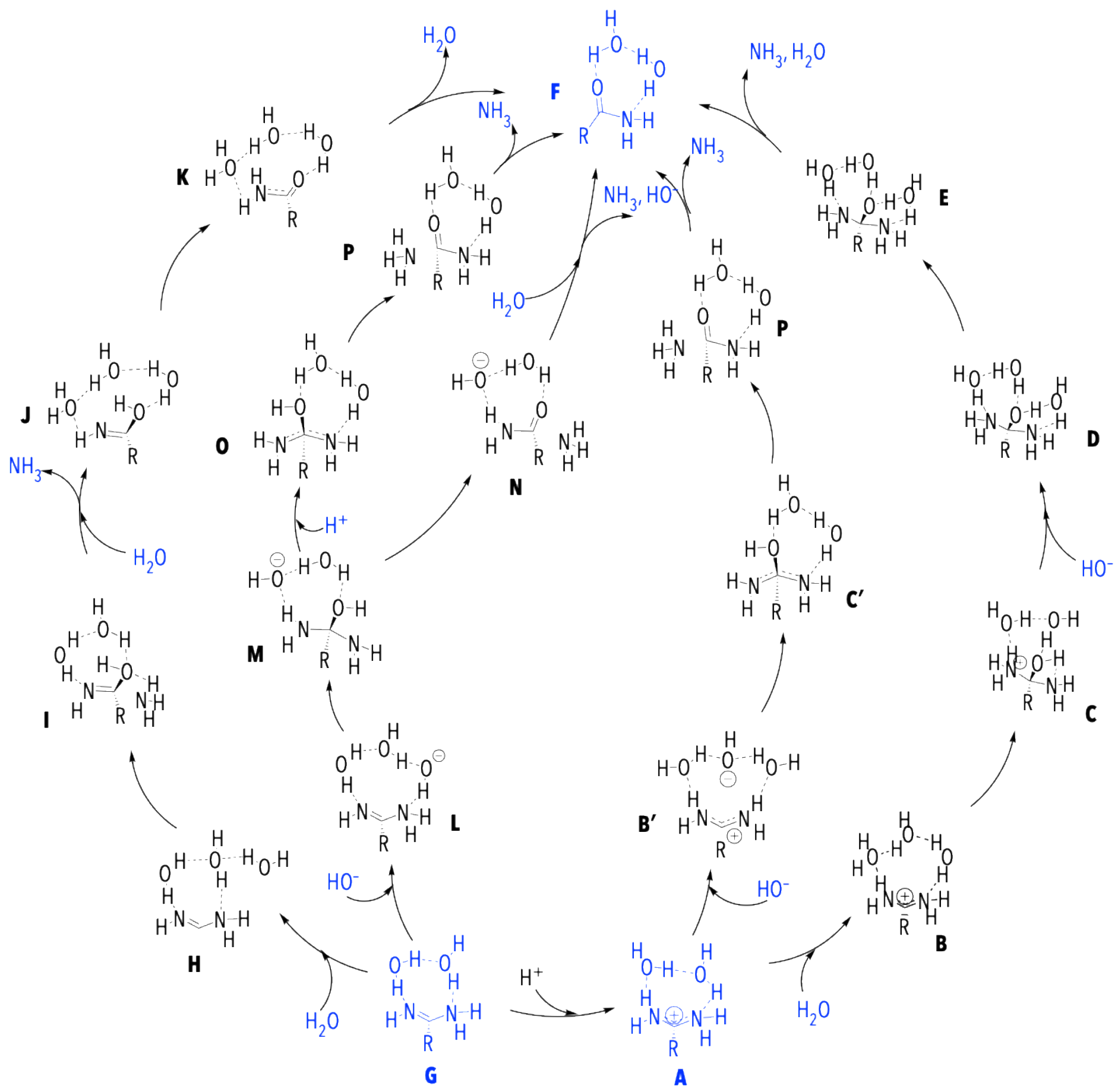

Scheme S1. Possible hydrolysis pathways of benzamidinium $(A)$ and benzamidine $(G)$ with $\mathrm{HO}^{-}$or $\mathrm{H}_{2} \mathrm{O}\left(\mathrm{R}=\mathrm{C}_{6} \mathrm{H}_{5}\right)$. The initial benzamidine reaction can proceed via 2 pathways; the one that also involves $\mathrm{H}^{+}$(i.e. $\mathrm{M} \rightarrow \mathrm{O} \rightarrow \mathrm{P} \rightarrow \mathrm{F}$ ) is indicated as $\mathrm{HO}^{-} / \mathrm{H}^{+}$in $\mathrm{Table}^{2}$ of the manuscript. The reactants, products and all intermediates are drawn complexed to two (additional) explicit waters, which reflects the cluster continuum modelling undertaken. Species labels are the same as those used in the Gaussian raw data section. 


\section{Kinetic model derivations}

Kinetic models for each pathway were derived assuming the steady state assumption, and assuming that the concentrations of $\left[\mathrm{H}^{+}\right]$, $\left[\mathrm{HO}^{-}\right]$and $\left[\mathrm{H}_{2} \mathrm{O}\right]$ are constant. The kinetic schemes are simplified by not explicitly including reactant and product complexes, but adjusting relevant barriers to take account of their energies. For all pathways the final overall step is assumed to be irreversible, which is reasonable given the relative forward and reverse barriers for that final step. The rate coefficients for each step are obtained using the Eyring equation in conjunction with the quantum-chemically calculated Gibbs free energy barriers. For barrierless reactions, a diffusion-controlled rate coefficient of $10^{-7} \mathrm{~L} \mathrm{~mol}^{-1} \mathrm{~s}^{-1}$ is assumed, and for those barrierless cases the reverse barrier is approximated as the (endothermic) Gibbs reaction free energy.

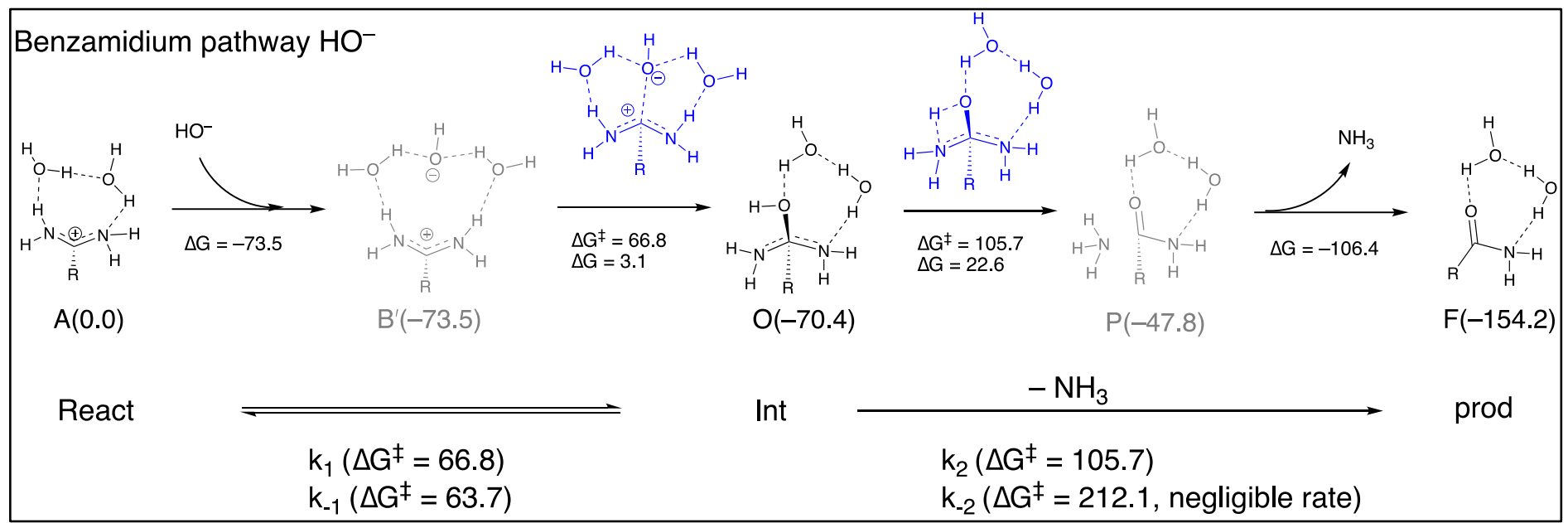

$\frac{d[\operatorname{prod}]}{d t}=k_{2}[$ int $]$

\section{Steady state:}

$\frac{d[\text { int }]}{d t}=k_{1}[$ HO $][$ react $]-k_{-1}[$ int $]-k_{2}[$ int $]=0$

$[$ int $]=\frac{k_{1}[\text { HO }][\text { react }]}{k_{-1}+k_{2}}$

\section{Substituting:}

$\frac{d[\text { prod }]}{d t}=k_{2}[$ int $]=\frac{k_{2} k_{1}[\text { HO }][\text { react }]}{k_{-1}+k_{2}}=k^{\prime}[$ react $]$

where:

$k^{\prime}=\frac{k_{1} k_{2}[H O]}{k_{-1}+k_{2}}$ 


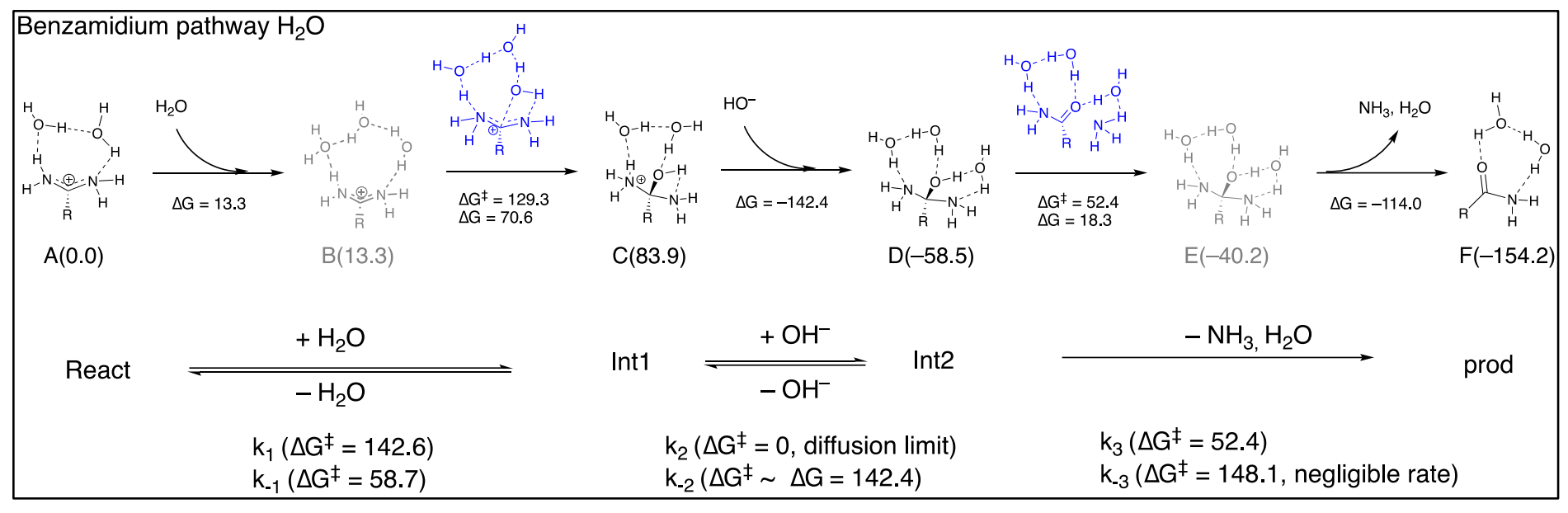

$\frac{d[\operatorname{prod}]}{d t}=k_{3}[$ int 2$]$

\section{Steady state:}

$\frac{d[\text { int } 1]}{d t}=k_{1}\left[H_{2} O\right][$ react $]-k_{-1}[$ int 1$]-k_{2}[O H][$ int 1$]+k_{-2}[$ int 2$]=0$

$\frac{d[\text { int } 2]}{d t}=k_{2}[\mathrm{OH}][$ int 1$]-k_{3}[$ int 2$]-k_{-2}[$ int 2$]=0$

\section{Solving Simultaneously:}

$\frac{d[\text { int } 1]}{d t}=k_{1}\left[H_{2} O\right][$ react $]-k_{-1}[$ int 1$]-k_{2}[O H][$ int 1$]+k_{-2}[$ int 2$]=0$

$[$ int 1$]=\frac{k_{1}\left[H_{2} O\right][\text { react }]+k_{-2}[\text { int } 2]}{k_{-1}+k_{2}[O H]}$

$\frac{d[\text { int } 2]}{d t}=k_{2}[\mathrm{OH}][\operatorname{int} 1]-k_{3}[$ int 2$]-k_{-2}[$ int 2$]=0$

$[$ int 2$]=\frac{k_{2}[O H][\text { int } 1]}{k_{3}+k_{-2}}$

$[$ int 2$]=\frac{k_{2}[\mathrm{OH}]\left(k_{1}\left[\mathrm{H}_{2} \mathrm{O}\right][\text { react }]+k_{-2}[\text { int } 2]\right)}{\left(k_{3}+k_{-2}\right)\left(k_{-1}+k_{2}[\mathrm{OH}]\right)}$

$[$ int 2$]\left(k_{3}+k_{-2}\right)\left(k_{-1}+k_{2}[\mathrm{OH}]\right)-k_{2}[\mathrm{OH}] k_{-2}[$ int 2$]=k_{2}[\mathrm{OH}] k_{1}\left[\mathrm{H}_{2} \mathrm{O}\right][$ react $]$

$[$ int 2$]\left(k_{3} k_{-1}+k_{3} k_{2}[\mathrm{OH}]+k_{-2} k_{-1}\right)=k_{2}[\mathrm{OH}] k_{1}\left[\mathrm{H}_{2} \mathrm{O}\right][$ react $]$

$[$ int 2$]=\frac{k_{2}[\mathrm{OH}] k_{1}\left[\mathrm{H}_{2} \mathrm{O}\right][\text { react }]}{k_{3} k_{-1}+k_{3} k_{2}[\mathrm{OH}]+k_{-2} k_{-1}}$

\section{Substituting:}

$\frac{d[\text { prod }]}{d t}=\frac{k_{3} k_{2}[\mathrm{OH}] k_{1}\left[\mathrm{H}_{2} \mathrm{O}\right][\text { react }]}{k_{3} k_{-1}+k_{3} k_{2}[\mathrm{OH}]+k_{-2} k_{-1}}=k^{\prime}[$ react $]$

where:

$k^{\prime}=\frac{k_{3} k_{2}[\mathrm{OH}] k_{1}\left[\mathrm{H}_{2} \mathrm{O}\right]}{k_{3} k_{-1}+k_{3} k_{2}[\mathrm{OH}]+k_{-2} k_{-1}}$ 


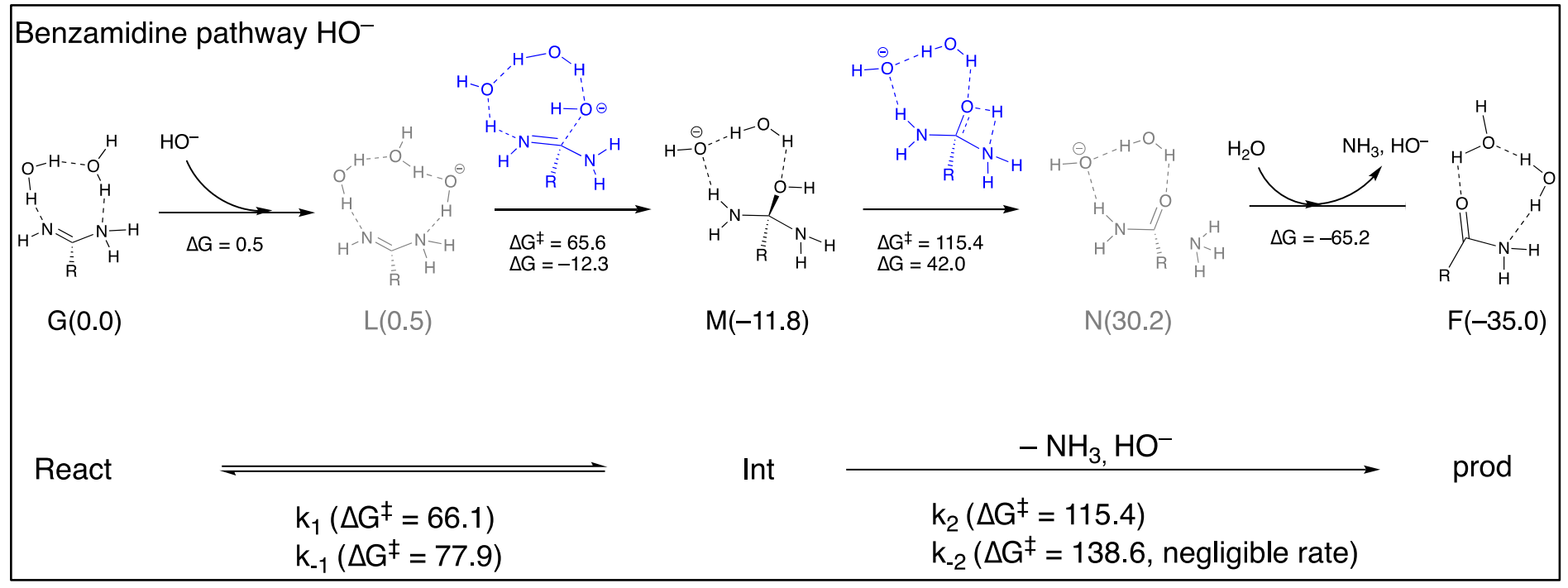

$\frac{d[\text { prod }]}{d t}=k_{2}[$ int $]$

\section{Steady state:}

$\frac{d[\text { int }]}{d t}=k_{1}[$ HO $][$ react $]-k_{-1}[$ int $]-k_{2}[$ int $]=0$

$[$ int $]=\frac{k_{1}[\text { HO }][\text { react }]}{k_{-1}+k_{2}}$

\section{Substituting:}

$\frac{d[\text { prod }]}{d t}=k_{2}[$ int $]=\frac{k_{2} k_{1}[\text { HO }][\text { react }]}{k_{-1}+k_{2}}=k^{\prime}[$ react $]$

where:

$k^{\prime}=\frac{k_{1} k_{2}[H O]}{k_{-1}+k_{2}}$ 


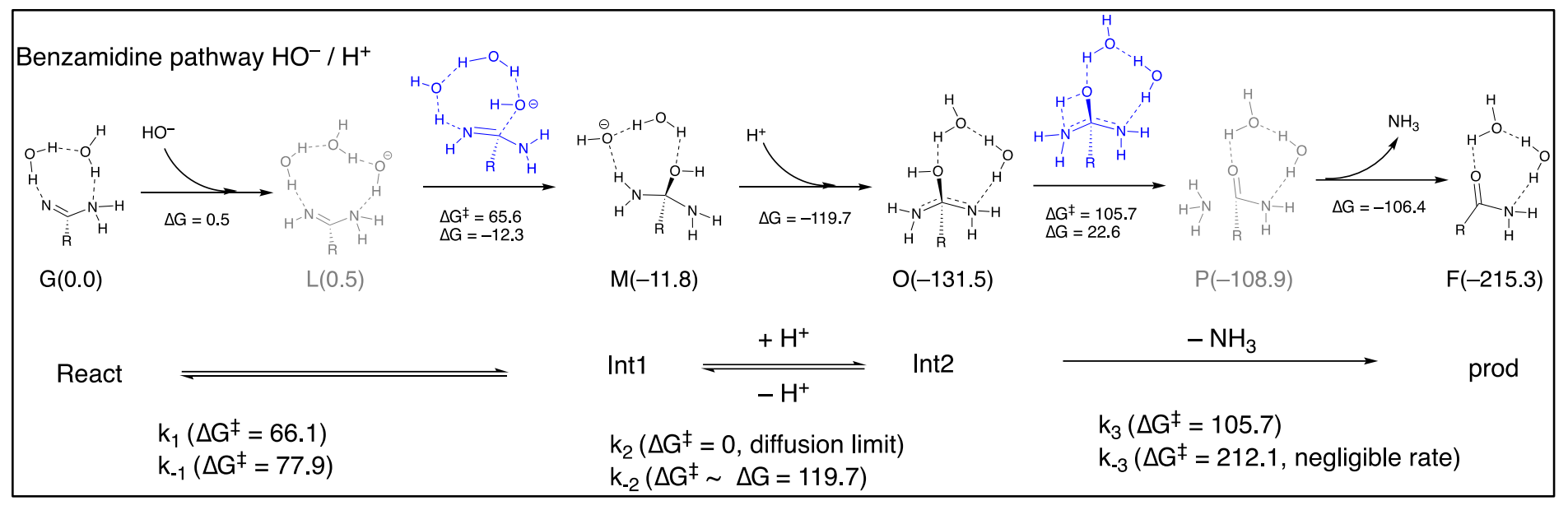

$\frac{d[\operatorname{prod}]}{d t}=k_{3}[$ int 2$]$

\section{Steady state:}

$\frac{d[\text { int } 1]}{d t}=k_{1}[$ HO $][$ react $]-k_{-1}[$ int 1$]-k_{2}[H][$ int 1$]+k_{-2}[$ int 2$]=0$

$\frac{d[\text { int } 2]}{d t}=k_{2}[H][$ int 1$]-k_{3}[$ int 2$]-k_{-2}[$ int 2$]=0$

\section{Solving Simultaneously:}

$\frac{d[\text { int } 1]}{d t}=k_{1}[H O][$ react $]-k_{-1}[$ int 1$]-k_{2}[H][$ int 1$]+k_{-2}[$ int 2$]=0$

$[$ int 1$]=\frac{k_{1}[\text { HO }][\text { react }]+k_{-2}[\text { int } 2]}{k_{-1}+k_{2}[H]}$

$\frac{d[\text { int } 2]}{d t}=k_{2}[H][$ int 1$]-k_{3}[$ int 2$]-k_{-2}[$ int 2$]=0$

$[$ int 2$]=\frac{k_{2}[H][\text { int } 1]}{k_{3}+k_{-2}}$

$[$ int 2$]=\frac{k_{2}[H]\left(k_{1}[\text { HO }][\text { react }]+k_{-2}[\text { int } 2]\right)}{\left(k_{3}+k_{-2}\right)\left(k_{-1}+k_{2}[H]\right)}$

$[$ int 2$]\left(k_{3}+k_{-2}\right)\left(k_{-1}+k_{2}[H]\right)-k_{2}[H] k_{-2}[$ int 2$]=k_{2}[H] k_{1}[H O][$ react $]$

$[$ int 2$]\left(k_{3} k_{-1}+k_{3} k_{2}[H]+k_{-2} k_{-1}\right)=k_{2}[H] k_{1}[$ HO $][$ react $]$

$[$ int 2$]=\frac{k_{2}[H] k_{1}[H O][\text { react }]}{k_{3} k_{-1}+k_{3} k_{2}[H]+k_{-2} k_{-1}}$

\section{Substituting:}

$\frac{d[\text { prod }]}{d t}=\frac{k_{3} k_{2}[H] k_{1}[\text { HO }][\text { react }]}{k_{3} k_{-1}+k_{3} k_{2}[H]+k_{-2} k_{-1}}=k^{\prime}[$ react $]$

where:

$k^{\prime}=\frac{k_{3} k_{2}[H] k_{1}[H O]}{k_{3} k_{-1}+k_{3} k_{2}[H]+k_{-2} k_{-1}}$ 


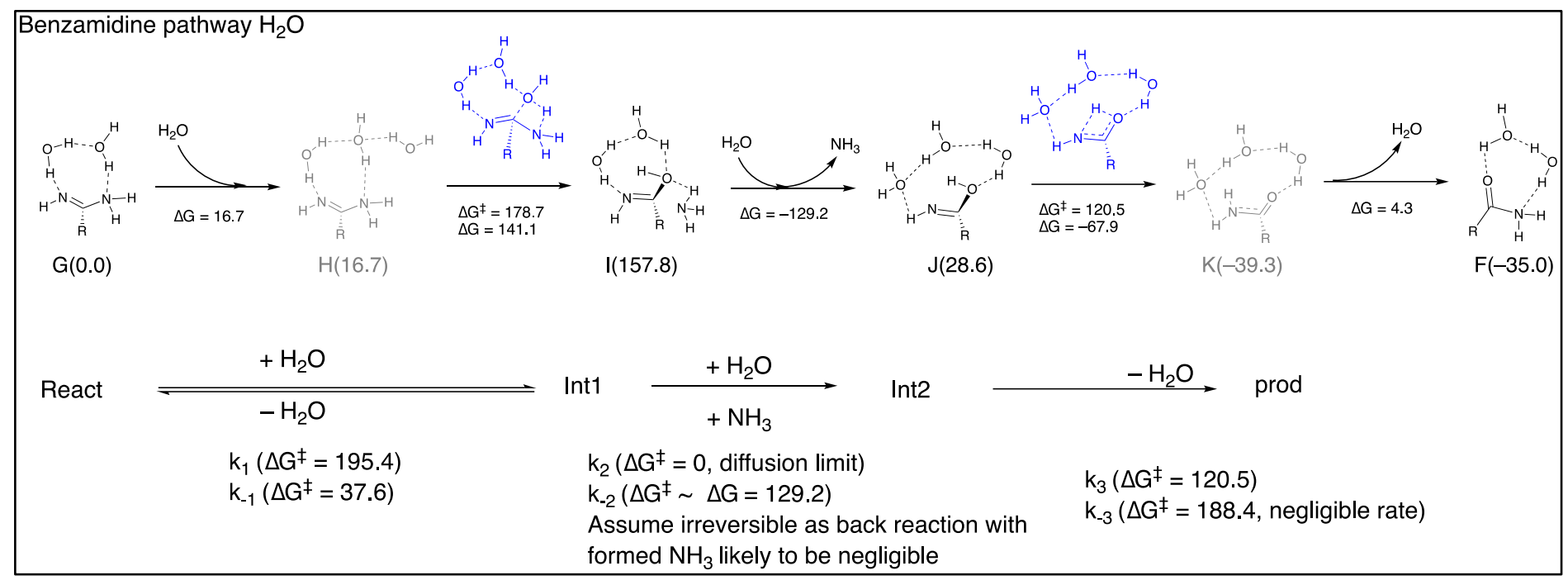

$\frac{d[\text { prod }]}{d t}=k_{3}[$ int 2$]$

\section{Steady state:}

$\frac{d[\text { int } 1]}{d t}=k_{1}\left[H_{2} O\right][$ react $]-k_{-1}[$ int 1$]-k_{2}\left[H_{2} O\right][$ int 1$]=0$

$\frac{d[i n t 2]}{d t}=k_{2}\left[H_{2} O\right][i n t 1]-k_{3}[$ int 2$]=0$

\section{Solving Simultaneously:}

$\frac{d[\text { int } 1]}{d t}=k_{1}\left[H_{2} O\right][$ react $]-k_{-1}[$ int 1$]-k_{2}\left[H_{2} O\right][$ int 1$]=0$

$[$ int 1$]=\frac{k_{1}\left[H_{2} O\right][\text { react }]}{k_{-1}+k_{2}\left[H_{2} O\right]}$

$\frac{d[\text { int } 2]}{d t}=k_{2}\left[H_{2} O\right][$ int 1$]-k_{3}[$ int 2$]=0$

$[$ int 2$]=\frac{k_{2}\left[H_{2} O\right][i n t 1]}{k_{3}}$

$[$ int 2$]=\frac{k_{2}\left[H_{2} O\right] k_{1}\left[H_{2} O\right][\text { react }]}{k_{3}\left(k_{-1}+k_{2}\left[H_{2} O\right]\right)}$

\section{Substituting:}

$\frac{d[\text { prod }]}{d t}=k_{3}[$ int 2$]=\frac{k_{3} k_{2}\left[H_{2} O\right] k_{1}\left[H_{2} O\right][\text { react }]}{k_{3}\left(k_{-1}+k_{2}\left[H_{2} O\right]\right)}=k^{\prime}[$ react $]$

where:

$k^{\prime}=\frac{k_{1} k_{2}\left[\mathrm{H}_{2} \mathrm{O}\right]^{2}}{k_{-1}+k_{2}\left[\mathrm{H}_{2} \mathrm{O}\right]}$

Note that the rate coefficient for this pathway as calculated is $1.9 \times 10^{-20}$ at all $\mathrm{pH}$ values and is more than 10 orders of magnitude slower than the $\mathrm{HO}^{-}$pathways and does not contribute. Allowing the back reaction of int 1 would only slow the process further so the assumption does not affect the outcome. 


\section{Sensitivity analysis}

Table S2. Sensitivity Analysis. Effect on the $\mathrm{pH}$-dependent half-lives for the overall process of scaling each individual rate coefficient in turn by a factor of 0.1 or 10 , while keeping all other rate coefficients at their correct $298 \mathrm{~K}$ values. ${ }^{a}$

\begin{tabular}{|c|c|c|c|c|c|c|c|c|c|c|}
\hline $\mathrm{pH}$ & $\mathbf{k}_{1} / 10$ & $k_{1}^{*} 10$ & $k_{-1} / 10$ & $k_{-1}{ }^{*} 10$ & $k_{2} / 10$ & $k_{2}^{*} 10$ & $\mathrm{k}_{-2} / \mathbf{1 0}$ & $k_{-2}{ }^{*} 10$ & $k_{3} / 10$ & $\mathbf{k}_{3}{ }^{*} 10$ \\
\hline & \multicolumn{10}{|c|}{ benzamidinium $\mathrm{HO}^{-}$} \\
\hline 9 & 294.4 & 293.8 & 293.8 & 294.4 & 294.4 & 293.8 & - & - & - & - \\
\hline 10 & 28.3 & 28.2 & 28.2 & 28.3 & 28.3 & 28.2 & - & - & - & - \\
\hline 11 & 3.4 & 3.4 & 3.4 & 3.4 & 3.4 & 3.4 & - & - & - & - \\
\hline 12 & 1 & 1 & 1 & 1 & 1 & 1 & - & - & - & - \\
\hline 13 & 0.7 & 0.7 & 0.7 & 0.7 & 0.7 & 0.7 & - & - & - & - \\
\hline \multirow[t]{2}{*}{14} & 0.5 & 0.5 & 0.5 & 0.5 & 0.5 & 0.5 & - & - & - & - \\
\hline & \multicolumn{10}{|c|}{ benzamidine $\mathrm{HO}^{-}$} \\
\hline 9 & 294.3 & 294.3 & 294.3 & 294.3 & 294.3 & 294.3 & - & - & - & - \\
\hline 10 & 28.3 & 28.3 & 28.3 & 28.3 & 28.3 & 28.3 & - & - & - & - \\
\hline 11 & 3.4 & 3.4 & 3.4 & 3.4 & 3.4 & 3.4 & - & - & - & - \\
\hline 12 & 1 & 0.9 & 0.9 & 1 & 1 & 0.9 & - & - & - & - \\
\hline 13 & 0.7 & 0.5 & 0.5 & 0.7 & 0.7 & 0.5 & - & - & - & - \\
\hline \multirow[t]{2}{*}{14} & 0.7 & 0.1 & 0.1 & 0.7 & 0.7 & 0.1 & - & - & - & - \\
\hline & \multicolumn{10}{|c|}{ benzamidine $\mathrm{HO}^{-} / \mathrm{H}^{+}$} \\
\hline 9 & 2938 & 29.4 & 47.4 & 2759.5 & 2759.5 & 47.4 & 293.5 & 303 & 303 & 293.5 \\
\hline 10 & 282.1 & 2.8 & 3 & 280.3 & 280.3 & 3 & 28.2 & 29.1 & 29.1 & 28.2 \\
\hline 11 & 34.1 & 0.3 & 0.3 & 34.1 & 34.1 & 0.3 & 3.4 & 3.5 & 3.5 & 3.4 \\
\hline 12 & 9.3 & 0.1 & 0.1 & 9.3 & 9.3 & 0.1 & 1 & 1 & 1 & 1 \\
\hline 13 & 5.2 & 0.1 & 0.1 & 5.2 & 5.2 & 0.1 & 0.7 & 0.7 & 0.7 & 0.7 \\
\hline 14 & 1.5 & 0.1 & 0.1 & 1.5 & 1.5 & 0.1 & 0.5 & 0.5 & 0.5 & 0.5 \\
\hline
\end{tabular}

aThe half-life is calculated from the overall rate coefficient for hydrolysis, obtained as a weighted sum of those for benzamidinium and benzamidine, weighted by their speciation at the given $\mathrm{pH}$. Unless otherwise specified, these in turn were calculated using quantum-chemical predicted rate and equilibrium coefficients for the individual steps in each hydrolysis pathway shown in Scheme S1. For each entry in the table, one rate coefficient was artificially increased or decreased by a factor of 10 . 


\section{Gaussian raw data}

Table S3. Total Energies, Entropies and Enthalpies. All values in a.u., except for $\mathrm{S}\left(\mathrm{J} \mathrm{mol}^{-1} \mathrm{~K}^{-1}\right)$ at $298 \mathrm{~K}$, which was used to calculate $\Delta \mathrm{G}$ and $\Delta \mathrm{G}^{\ddagger}$ (in $\mathrm{kJ}$ mol$\left.{ }^{-1}\right)$.

\begin{tabular}{|c|c|c|c|c|c|c|c|c|c|c|c|c|}
\hline Species & Ee & TPVE & TC & $\mathbf{S}$ & TS & $\mathrm{H}$ & $\mathbf{G}$ & $\begin{array}{c}\text { Ee } \\
\text { (low, gas) }\end{array}$ & $\begin{array}{c}\text { Ee } \\
\text { (high,gas) }\end{array}$ & $\begin{array}{c}\text { G } \\
\text { (high, soln) }\end{array}$ & NImag $^{a}$ & $\begin{array}{c}\text { Imag Freq } \\
\left(\mathrm{cm}^{-1}\right)\end{array}$ \\
\hline A & -534.236508 & 0.194604 & 0.016622 & 528.8782 & 0.060059 & -534.025281 & -534.085340 & -534.127248 & -534.311571 & -534.266654 & 0 & - \\
\hline B & -610.660004 & 0.219654 & 0.018309 & 546.2557 & 0.062032 & -610.422042 & -610.484074 & -610.535033 & -610.750283 & -610.696315 & 0 & - \\
\hline B_C_TS & -610.615984 & 0.220171 & 0.016143 & 507.3036 & 0.057609 & -610.379670 & -610.437279 & -610.498133 & -610.710934 & -610.647070 & 1 & $316.9 i$ \\
\hline B_prim & -610.180833 & 0.204304 & 0.017157 & 540.9793 & 0.061433 & -609.959372 & -610.020805 & -610.119836 & -610.332025 & -610.229985 & 0 & - \\
\hline B_prim_C_prim_TS & -610.159159 & 0.205467 & 0.016223 & 512.4319 & 0.058191 & -609.937469 & -609.995660 & -610.130661 & -610.342556 & -610.204546 & 1 & $477.7 i$ \\
\hline C & -610.643717 & 0.224549 & 0.016272 & 505.7430 & 0.057432 & -610.402896 & -610.460328 & -610.520379 & -610.732504 & -610.669445 & 0 & - \\
\hline C_prim & -610.187534 & 0.210307 & 0.016503 & 522.7009 & 0.059358 & -609.960725 & -610.020082 & -610.139126 & -610.350843 & -610.228791 & 0 & - \\
\hline C_prim_D_prim_TS & -610.143495 & 0.205558 & 0.015853 & 508.0964 & 0.057699 & -609.922084 & -609.979783 & -610.087683 & -610.299443 & -610.188534 & 1 & $1613.1 \mathrm{i}$ \\
\hline D & -686.846444 & 0.234268 & 0.019276 & 577.5580 & 0.065587 & -686.592899 & -686.658486 & -686.555970 & -686.798009 & -686.897515 & 0 & - \\
\hline D_E_TS & -686.588432 & 0.230957 & 0.017508 & 536.0531 & 0.060874 & -686.339967 & -686.400841 & -686.520029 & -686.761270 & -686.639073 & 1 & $426.6 \mathrm{i}$ \\
\hline E & -686.839991 & 0.234241 & 0.019059 & 568.2652 & 0.064532 & -686.586692 & -686.651223 & -686.523031 & -686.765253 & -686.890436 & 0 & - \\
\hline $\mathbf{F}$ & -553.656642 & 0.170419 & 0.015406 & 505.7503 & 0.057433 & -553.470817 & -553.528250 & -553.612574 & -553.809346 & -553.722013 & 0 & - \\
\hline G & -533.772545 & 0.182573 & 0.015287 & 509.0378 & 0.057806 & -533.574686 & -533.632492 & -533.733780 & -533.916925 & -533.812629 & 0 & - \\
\hline $\mathbf{H}$ & -610.190183 & 0.206359 & 0.018322 & 569.5064 & 0.064673 & -609.965502 & -610.030175 & -610.142559 & -610.356421 & -610.241028 & 0 & - \\
\hline H_I_TS & -610.128079 & 0.208091 & 0.016045 & 525.4375 & 0.059668 & -609.903943 & -609.963611 & -610.066811 & -610.279143 & -610.172934 & 1 & $301.6 \mathrm{i}$ \\
\hline $\mathbf{I}$ & -610.144664 & 0.208451 & 0.016795 & 527.4265 & 0.059894 & -609.919418 & -609.979312 & -610.084455 & -610.295416 & -610.187263 & 0 & - \\
\hline $\mathbf{J}$ & -553.635163 & 0.171455 & 0.015212 & 501.2304 & 0.056919 & -553.448496 & -553.505416 & -553.597878 & -553.793200 & -553.697729 & 0 & - \\
\hline J_K_TS & -553.582427 & 0.165094 & 0.015066 & 500.2379 & 0.056807 & -553.402267 & -553.459073 & -553.546674 & -553.742450 & -553.651840 & 1 & $2002.7 i$ \\
\hline K & -553.659358 & 0.170471 & 0.015233 & 499.2351 & 0.056693 & -553.473654 & -553.530347 & -553.619671 & -553.815908 & -553.723575 & 0 & - \\
\hline $\mathbf{L}$ & -609.689790 & 0.193427 & 0.018428 & 573.8254 & 0.065163 & -609.477935 & -609.543098 & -609.516769 & -609.724441 & -609.747761 & 0 & - \\
\hline L_M_TS & -609.664574 & 0.193258 & 0.016643 & 531.2231 & 0.060325 & -609.454673 & -609.514998 & -609.543641 & -609.754424 & -609.722773 & 1 & $347.2 \mathrm{i}$ \\
\hline M & -609.701352 & 0.196044 & 0.015760 & 502.9484 & 0.057114 & -609.489548 & -609.546662 & -609.555898 & -609.764697 & -609.752452 & 0 & - \\
\hline M_N_TS & -609.653416 & 0.192143 & 0.015361 & 501.5225 & 0.056953 & -609.445912 & -609.502865 & -609.496605 & -609.705258 & -609.708510 & 1 & $1561.5 \mathrm{i}$ \\
\hline $\mathbf{N}$ & -609.688564 & 0.197627 & 0.015328 & 492.3866 & 0.055915 & -609.475609 & -609.531524 & -609.509099 & -609.717033 & -609.736449 & 0 & - \\
\hline 0 & -610.187534 & 0.210307 & 0.016503 & 522.7009 & 0.059358 & -609.960725 & -610.020082 & -610.139126 & -610.350843 & -610.228791 & 0 & - \\
\hline O_P_TS & -610.143495 & 0.205558 & 0.015853 & 508.0964 & 0.057699 & -609.922084 & -609.979783 & -610.087683 & -610.299443 & -610.188534 & 1 & $1613.1 \mathrm{i}$ \\
\hline $\mathbf{P}$ & -610.181025 & 0.210793 & 0.015756 & 502.7564 & 0.057093 & -609.954476 & -610.011569 & -610.104011 & -610.315641 & -610.220190 & 0 & - \\
\hline $\mathrm{H}_{2} \mathrm{O}$ & -76.409511 & 0.020511 & 0.003782 & 188.7648 & 0.021436 & -76.385218 & -76.406654 & -76.394925 & -76.426021 & -76.434741 & 0 & - \\
\hline $\mathrm{NH}_{3}$ & -56.536128 & 0.033150 & 0.003819 & 192.4784 & 0.021858 & -56.499159 & -56.521017 & -56.528840 & -56.549577 & -56.538745 & 0 & - \\
\hline $\mathrm{HO}^{-}$ & -75.913945 & 0.008519 & 0.003305 & 172.2125 & 0.019556 & -75.902121 & -75.921678 & -75.758879 & -75.775546 & -75.935336 & 0 & - \\
\hline
\end{tabular}


Optimized solution phase geometries

\section{A.xyz}

$\begin{array}{llll}\text { C } & -2.718625 & 1.241385 & -0.371908\end{array}$

C $\quad-1.351832 \quad 1.020342-0.515983$

$\begin{array}{llll}-0.811445 & -0.221941 & -0.165566\end{array}$

$\begin{array}{lll}-1.637003 & -1.239927 & 0.325112\end{array}$

$\begin{array}{llll}-3.003937 & -1.013282 & 0.456330\end{array}$

$\begin{array}{lll}-3.544327 & 0.225913 & 0.111008\end{array}$

$\begin{array}{llll}-3.136426 & 2.208431 & -0.631248\end{array}$

$\begin{array}{llll}-0.707772 & 1.818894 & -0.872564\end{array}$

$\begin{array}{llll}-1.221740 & -2.210667 & 0.579500\end{array}$

$\begin{array}{llll}-3.646494 & -1.806028 & 0.824725\end{array}$

$\begin{array}{lll}-4.610110 & 0.400612 & 0.219245\end{array}$

$\begin{array}{llll}0.643119 & -0.453001 & -0.302431\end{array}$

$\begin{array}{llll}1.276168 & -1.179243 & 0.598410\end{array}$

$\begin{array}{llll}1.298067 & 0.064413 & -1.322656\end{array}$

$\begin{array}{llll}0.801376 & 0.559418 & -2.052195\end{array}$

$\begin{array}{lll}0.790661 & -1.495762 & 1.427953\end{array}$

$2.273408 \quad 1.930662 \quad 1.283041$

$\begin{array}{lll}2.213707 & 1.096823 & 1.767745\end{array}$

$\begin{array}{llll}2.734129 & 1.704383 & 0.464064\end{array}$

$\begin{array}{lll}2.311935 & -0.029201 & -1.375324\end{array}$

$\begin{array}{llll}4.400827 & 0.032476 & 0.220258\end{array}$

$\begin{array}{lll}3.937306 & -0.598103 & -0.348020\end{array}$

$\begin{array}{llll}4.626985 & -1.166672 & -0.715963\end{array}$

$2.281878 \quad-1.326303 \quad 0.513981$
B.xyz

$\begin{array}{llll}\text { C } & 2.265274 & -1.141478 & 0.689640\end{array}$

$\begin{array}{llll}\text { C } & 0.938134 & -1.431645 & 0.384449\end{array}$

$\begin{array}{llll}0.263604 & -0.661599 & -0.569638\end{array}$

$\begin{array}{llll}0.920242 & 0.385181 & -1.226414\end{array}$

$\begin{array}{llll}\text { C } & 2.249566 & 0.663600 & -0.921683\end{array}$

$\begin{array}{llll}\text { C } & 2.920102 & -0.094167 & 0.039636\end{array}$

H $\quad 2.784222 \quad-1.728613 \quad 1.439924$

$\begin{array}{llll}0.426883 & -2.234631 & 0.908429\end{array}$

$\begin{array}{llll}0.403093 & 0.966527 & -1.983961\end{array}$

$\begin{array}{llll}2.761494 & 1.469716 & -1.436602\end{array}$

$\begin{array}{llll}3.954620 & 0.129277 & 0.280280\end{array}$

$\begin{array}{llll}-1.159673 & -0.930939 & -0.867768\end{array}$

$\begin{array}{llll}-1.963570 & 0.080028 & -1.118611\end{array}$

$\begin{array}{llll}-2.938213 & -0.083664 & -1.348284\end{array}$

$\begin{array}{llll}N & -1.598402 & -2.175221 & -0.882389\end{array}$

$\begin{array}{llll}-0.952744 & -2.948625 & -0.786325\end{array}$

$\begin{array}{llll}-2.580276 & -2.382494 & -1.029390\end{array}$

$\begin{array}{llll}-1.648275 & 1.042928 & -0.972479\end{array}$

$\begin{array}{llll}-1.852807 & -0.495149 & 2.273068\end{array}$

$\begin{array}{llll}-1.439033 & -1.346598 & 2.083109\end{array}$

$\begin{array}{llll}-1.171000 & 0.177750 & 2.072973\end{array}$

$\begin{array}{llll}-1.042195 & 2.765353 & -0.536520\end{array}$

$\begin{array}{llll}-0.399708 & 3.151756 & -1.147858\end{array}$

$\begin{array}{llll}-1.684316 & 3.464938 & -0.352689\end{array}$

$\begin{array}{llll}-0.041396 & 1.604110 & 1.822830\end{array}$

$\begin{array}{llll}H & -0.315881 & 2.016605 & 0.980135\end{array}$

$\begin{array}{llll}H & 0.840624 & 1.243251 & 1.655373\end{array}$

\section{B_C_TS.xyz}

$\begin{array}{llll}\text { C } & -2.651018 & 0.656091 & 0.599956\end{array}$

$\begin{array}{llll}\text { C } & -1.356855 & 1.162070 & 0.535612\end{array}$

$\begin{array}{lllll}\text { C } & -0.417599 & 0.583646 & -0.326407\end{array}$

C $\quad-0.783818-0.509906-1.114250$

$\begin{array}{llll}\text { C } & -2.084822 & -1.009407 & -1.051726\end{array}$

C $\quad-3.018584 \quad-0.431037 \quad-0.195200$

$\begin{array}{llll}H & -3.369515 & 1.105763 & 1.277405\end{array}$

$\begin{array}{llll}H & -1.079343 & 1.987763 & 1.185569\end{array}$

$\begin{array}{llll}H & -0.068599 & -0.988781 & -1.774610\end{array}$

H $\quad-2.361202 \quad-1.856954 \quad-1.670414$

$\begin{array}{llll}-4.027812 & -0.826828 & -0.142177\end{array}$

$\begin{array}{llll}0.989585 & 1.108951 & -0.353450\end{array}$

$\begin{array}{llll}N & 1.912926 & 0.369895 & -1.122163\end{array}$

$\begin{array}{llll}H & 2.819116 & 0.835305 & -1.134481\end{array}$

$\begin{array}{llll}N & 1.133775 & 2.452462 & -0.340025\end{array}$

$\begin{array}{llll}0.475105 & 3.009140 & 0.191884\end{array}$

$\begin{array}{lll}2.079652 & 2.817625 & -0.376500\end{array}$

$\begin{array}{llll}H & 1.577940 & 0.303159 & -2.083204\end{array}$

$\begin{array}{lllll}\text { O } & 1.577990 & 0.566649 & 1.266463\end{array}$

H $\quad 1.301294 \quad 1.229935 \quad 1.921798$

$\begin{array}{llll}1.131105 & -0.316723 & 1.535794\end{array}$

$\begin{array}{llll}1.958715 & -2.417699 & -0.351499\end{array}$

H $\quad 1.497290 \quad-2.869228 \quad-1.071004$

$\begin{array}{llll}H & 2.006791 & -1.475008 & -0.626476\end{array}$

$\begin{array}{llll}\text { O } & 0.488873 & -1.685814 & 1.806905\end{array}$

H $\quad 0.884666 \quad-2.161708 \quad 1.040151$

$\begin{array}{llll}H & -0.459354 & -1.617488 & 1.619427\end{array}$ 


\section{B_prim.xyz}

$\begin{array}{llll}\text { C } & 2.926181 & 1.127589 & 0.687003\end{array}$ $\begin{array}{llll}1.581665 & 0.786081 & 0.800451\end{array}$ $\begin{array}{lll}1.095846 & -0.348438 & 0.140031\end{array}$ $\begin{array}{lll}1.958613 & -1.141633 & -0.624383\end{array}$ $\begin{array}{lll}3.303781 & -0.798271 & -0.725827\end{array}$ $\begin{array}{lll}3.787364 & 0.335965 & -0.073525\end{array}$ $\begin{array}{llll}3.298969 & 2.014455 & 1.188456\end{array}$ $0.912479 \quad 1.416358 \quad 1.379908$ $\begin{array}{llll}1.590588 & -2.035434 & -1.119145\end{array}$ $\begin{array}{llll}3.973741 & -1.420145 & -1.310178\end{array}$ $\begin{array}{llll}4.836006 & 0.603188 & -0.157632\end{array}$ $\begin{array}{lll}-0.333171 & -0.714632 & 0.255640\end{array}$ $\begin{array}{lll}-0.948844 & -1.289769 & -0.760183\end{array}$ $\begin{array}{lll}-0.983271 & -0.483161 & 1.378229\end{array}$ $\begin{array}{lll}-0.492988 & -0.127243 & 2.187874\end{array}$ $\begin{array}{llll}-0.495744 & -1.353848 & -1.662301\end{array}$ $\begin{array}{llll}-1.268049 & 2.131226 & -0.906619\end{array}$ $\begin{array}{llll}-2.180422 & 1.719240 & -0.699659\end{array}$ $\begin{array}{llll}-0.813621 & 2.208379 & -0.058813\end{array}$ $\begin{array}{lll}-1.985231 & -0.695725 & 1.426083\end{array}$ $\begin{array}{lll}-3.575241 & 1.118490 & -0.422955\end{array}$ $\begin{array}{lll}-3.620490 & -0.170540 & 0.044856\end{array}$ $\begin{array}{llll}-3.531415 & -1.177793 & 0.434238\end{array}$ $\begin{array}{llll}-4.395796 & -1.447321 & 0.766739\end{array}$ $\begin{array}{llll}-1.934139 & -1.540782 & -0.670936\end{array}$ $\begin{array}{llll}-4.092589 & 1.184576 & -1.235220\end{array}$

\section{B_prim_C_prim_TS.xyz}

C $\quad-3.008862 \quad-1.1549790 .539562$

$\begin{array}{llll}-1.630205 & -0.988259 & 0.611246\end{array}$

$\begin{array}{llll}-1.035265 & 0.175280 & 0.109041\end{array}$

$\begin{array}{lllll}\text { C } & -1.834970 & 1.169961 & -0.456352\end{array}$

$\begin{array}{llll}\text { C } & -3.218107 & 0.997125 & -0.530812\end{array}$

$\begin{array}{llll}\text { C } & -3.807416 & -0.162521 & -0.034325\end{array}$

$\begin{array}{llll}-3.460478 & -2.062895 & 0.926178\end{array}$

$\begin{array}{lll}-1.018718 & -1.778079 & 1.040789\end{array}$

$\begin{array}{llll}-1.389215 & 2.087014 & -0.826913\end{array}$

$\begin{array}{llll}-3.831336 & 1.776577 & -0.971626\end{array}$

$\begin{array}{llll}-4.883177 & -0.295494 & -0.091273\end{array}$

$\begin{array}{llll}0.441986 & 0.381175 & 0.223844\end{array}$

$\begin{array}{llll}1.006156 & 1.387573 & -0.484338\end{array}$

$\begin{array}{lll}1.020217 & 0.063927 & 1.391493\end{array}$

$\begin{array}{lll}0.591004 & -0.644092 & 1.970675\end{array}$

$\begin{array}{llll}0.691371 & 1.477977 & -1.442434\end{array}$

$\begin{array}{llll}0.920264 & -1.168222 & -1.045233\end{array}$

$\begin{array}{llll}2.333477 & -1.222530 & -0.896994\end{array}$

$\begin{array}{llll}0.551114 & -1.982239 & -0.675833\end{array}$

$\begin{array}{llll}2.027480 & 0.189003 & 1.471879\end{array}$

$3.386909-1.229369-0.762775$

$\begin{array}{lll}3.765276 & 0.123497 & 0.131894\end{array}$

$\begin{array}{lll}3.772334 & 0.950330 & 0.685650\end{array}$

$\begin{array}{llll}4.575077 & 0.919897 & 1.220603\end{array}$

$\begin{array}{llll}2.007019 & 1.510023 & -0.356648\end{array}$

$\begin{array}{llll}H & 3.777473 & -1.187761 & -1.644737\end{array}$

\section{C.xyz}

$\begin{array}{llll}\text { C } & 2.039091 & 1.162341 & 0.977554\end{array}$

$\begin{array}{llll}\text { C } & 0.764737 & 0.594568 & 1.016355\end{array}$

C $\quad 0.475358 \quad-0.5191320 .227906$

$\begin{array}{llll}\text { C } & 1.465380 & -1.064745 & -0.595914\end{array}$

$\begin{array}{llll}\text { C } & 2.733649 & -0.490738 & -0.637791\end{array}$

$\begin{array}{llll}\text { C } & 3.022376 & 0.625366 & 0.148848\end{array}$

$\begin{array}{llll}H & 2.258800 & 2.027520 & 1.594962\end{array}$

H $\quad 0.004642 \quad 1.025761 \quad 1.659159$

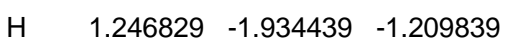

H $\quad 3.494984 \quad-0.915948 \quad-1.283882$

H $\quad 4.010892 \quad 1.072608 \quad 0.116278$

$\begin{array}{llll}\text { C } & -0.916300 & -1.135795 & 0.224186\end{array}$

$\begin{array}{llll}\mathrm{N} & -1.498286 & -0.983473 & -1.154280\end{array}$

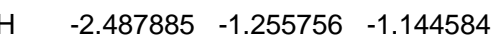

$\begin{array}{llll}N & -0.862864 & -2.530867 & 0.512989\end{array}$

$\begin{array}{llll}H & -0.290737 & -2.692366 & 1.338161\end{array}$

H $\quad-1.801831 \quad-2.887512 \quad 0.685873$

$\begin{array}{llll}H & -1.001344 & -1.593160 & -1.811245\end{array}$

$\begin{array}{llll}\text { O } & -1.842803 & -0.410331 & 1.001724\end{array}$

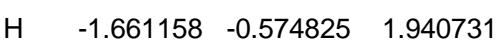

H $\quad-2.088335 \quad 1.482630 \quad 0.760553$

$\begin{array}{lllll}\text { O } & -0.864948 & 1.646754 & -1.870243\end{array}$

$\begin{array}{llll}\mathrm{H} & 0.093088 & 1.623060 & -1.732272\end{array}$

H $\quad-1.397495 \quad 0.008653 \quad-1.480176$

$\begin{array}{lllll}\mathrm{O} & -2.117979 & 2.415047 & 0.479241\end{array}$

H $\quad-1.232615 \quad 2.091628 \quad-1.077180$

$\begin{array}{llll}H & -1.519693 & 2.879577 & 1.079863\end{array}$ 


\section{C_prim.xyz}

$\begin{array}{llll}\text { C } & -2.817004 & 0.235873 & 0.675017\end{array}$ $\begin{array}{llll}-1.599652 & 0.908562 & 0.609917\end{array}$ $\begin{array}{lll}-0.554947 & 0.416758 & -0.182480\end{array}$ $\begin{array}{lll}-0.754380 & -0.751560 & -0.919882\end{array}$ $\begin{array}{llll}-1.977352 & -1.424139 & -0.856828\end{array}$ $\begin{array}{lll}-3.009372 & -0.936572 & -0.058666\end{array}$ $\begin{array}{lll}-3.616487 & 0.629142 & 1.295292\end{array}$ $\begin{array}{lll}-1.470838 & 1.828925 & 1.176270\end{array}$ $\begin{array}{llll}0.037316 & -1.142973 & -1.548867\end{array}$ $\begin{array}{llll}-2.118496 & -2.331920 & -1.435523\end{array}$ $\begin{array}{llll}-3.958181 & -1.461693 & -0.009847\end{array}$ $\begin{array}{llll}0.764084 & 1.187215 & -0.223819\end{array}$ $\begin{array}{llll}0.640428 & 2.537048 & -0.761869\end{array}$ $\begin{array}{llll}0.120036 & 2.496001 & -1.637474\end{array}$ $\begin{array}{llll}1.333411 & 1.219619 & 1.119184\end{array}$ $\begin{array}{lll}0.695364 & 1.700389 & 1.752606\end{array}$ $\begin{array}{llll}2.188697 & 1.775245 & 1.088574\end{array}$ $\begin{array}{llll}0.090477 & 3.104136 & -0.118743\end{array}$ $\begin{array}{llll}1.648104 & 0.488400 & -1.073721\end{array}$ $\begin{array}{llll}2.395372 & 1.076838 & -1.262840\end{array}$ $\begin{array}{lll}1.425562 & -1.478772 & 2.003964\end{array}$ $\begin{array}{llll}1.771745 & -1.932445 & 1.215789\end{array}$ $\begin{array}{llll}1.414989 & -0.529362 & 1.736019\end{array}$ $\begin{array}{llll}2.462211 & -2.177144 & -0.576598\end{array}$ $\begin{array}{llll}1.835610 & -2.728129 & -1.063612\end{array}$ $\begin{array}{llll}2.202252 & -1.257515 & -0.777565\end{array}$

\section{C_prim_D_prim_TS.xyz}

$\begin{array}{llll}\text { C } & -2.989790 & 0.185871 & 0.480647\end{array}$

$\begin{array}{lllll}\text { C } & -1.793303 & 0.899078 & 0.461713\end{array}$

C $\quad-0.650304 \quad 0.342322 \quad-0.121700$

C $\quad-0.714069-0.930056-0.687554$

C $\quad-1.912781-1.645653-0.665730$

$\begin{array}{llll}\text { C } & -3.050846 & -1.090157 & -0.083259\end{array}$

$\begin{array}{llll}-3.873455 & 0.626121 & 0.932011\end{array}$

$\begin{array}{lll}-1.751073 & 1.894611 & 0.899208\end{array}$

$\begin{array}{llll}0.172021 & -1.361045 & -1.142209\end{array}$

$\begin{array}{llll}-1.955123 & -2.636888 & -1.106432\end{array}$

$\begin{array}{llll}-3.982750 & -1.646787 & -0.069553\end{array}$

$\begin{array}{llll}0.659820 & 1.111635 & -0.106063\end{array}$

$\begin{array}{llll}0.518703 & 2.459739 & -0.808227\end{array}$

$\begin{array}{lll}-0.372642 & 2.603002 & -1.281560\end{array}$

$\begin{array}{lll}1.148789 & 1.223821 & 1.247559\end{array}$

$\begin{array}{lll}0.452973 & 1.651902 & 1.855798\end{array}$

$\begin{array}{lll}1.990330 & 1.799138 & 1.257886\end{array}$

$\begin{array}{llll}0.748017 & 3.261777 & -0.222073\end{array}$

$\begin{array}{llll}1.646908 & 0.632458 & -0.964772\end{array}$

$\begin{array}{llll}1.405873 & 1.825815 & -1.396181\end{array}$

$\begin{array}{lll}1.753349 & -1.521820 & 1.863051\end{array}$

$\begin{array}{llll}2.148380 & -1.796458 & 1.015763\end{array}$

$\begin{array}{llll}1.532439 & -0.574863 & 1.719782\end{array}$

$\begin{array}{lll}2.827177 & -1.781755 & -0.774281\end{array}$

$2.316414-2.396933-1.316043$

$\begin{array}{llll}H & 2.384313 & -0.903605 & -0.882035\end{array}$

\section{D.xyz}

$\begin{array}{llll}\text { C } & 2.550865 & -1.139886 & -0.841880\end{array}$

$\begin{array}{llll}1.252840 & -0.802889 & -1.218386\end{array}$

$\begin{array}{llll}0.306985 & -0.433561 & -0.254497\end{array}$

$\begin{array}{lll}0.675083 & -0.419289 & 1.090728\end{array}$

$\begin{array}{lll}1.976426 & -0.757852 & 1.468296\end{array}$

$\begin{array}{llll}2.917623 & -1.114608 & 0.504907\end{array}$

$\begin{array}{llll}3.275295 & -1.419450 & -1.600465\end{array}$

$\begin{array}{llll}0.984951 & -0.821878 & -2.272646\end{array}$

$\begin{array}{lll}-0.045184 & -0.134676 & 1.850961\end{array}$

$\begin{array}{llll}2.251305 & -0.738714 & 2.518337\end{array}$

$\begin{array}{lll}3.930028 & -1.373334 & 0.799021\end{array}$

$\begin{array}{llll}-1.096293 & -0.017827 & -0.698503\end{array}$

$\begin{array}{llll}-0.982235 & 1.140974 & -1.583464\end{array}$

$\begin{array}{llll}-0.571060 & 0.841713 & -2.467158\end{array}$

$\begin{array}{llll}-1.772953 & -1.181340 & -1.272319\end{array}$

$\begin{array}{lll}-2.160339 & -2.171168 & 0.307536\end{array}$

$\begin{array}{llll}-1.188383 & -1.603187 & -1.991486\end{array}$

$\begin{array}{llll}-1.924938 & 1.469068 & -1.795008\end{array}$

$\begin{array}{llll}-1.888292 & 0.446795 & 0.372354\end{array}$

$\begin{array}{llll}-2.631704 & -0.865611 & -1.723875\end{array}$

$\begin{array}{lll}-2.109510 & -0.312833 & 0.945653\end{array}$

$\begin{array}{llll}-2.270733 & -2.245763 & 1.282870\end{array}$

$\begin{array}{lll}-3.179309 & -2.542361 & 1.422838\end{array}$

$\begin{array}{lll}-0.686188 & 2.704556 & 1.689320\end{array}$

$\begin{array}{lll}0.040966 & 2.840522 & 1.054778\end{array}$

$\begin{array}{lll}-1.152586 & 1.928783 & 1.330440\end{array}$

$\begin{array}{llll}1.111656 & 2.723162 & -0.525818\end{array}$

$\begin{array}{llll}1.774170 & 2.050826 & -0.312695\end{array}$

$\begin{array}{llll}0.359893 & 2.220336 & -0.929547\end{array}$ 


\section{D_E_TS.xyz}

$\begin{array}{lll}2.630899 & 1.069685 & 0.762969\end{array}$

$\begin{array}{llll}1.311969 & 0.838232 & 1.145830\end{array}$

$\begin{array}{lll}0.357400 & 0.457934 & 0.195331\end{array}$

$0.731911 \quad 0.330446-1.141709$

$2.054202 \quad 0.563328-1.524466$

$\begin{array}{lll}3.006162 & 0.927273 & -0.574239\end{array}$

$\begin{array}{llll}3.364637 & 1.358676 & 1.508785\end{array}$

$\begin{array}{lll}1.035929 & 0.952244 & 2.192159\end{array}$

$\begin{array}{lll}-0.004458 & 0.038430 & -1.882996\end{array}$

$\begin{array}{llll}2.337704 & 0.455776 & -2.566771\end{array}$

$\begin{array}{llll}4.035336 & 1.102107 & -0.871931\end{array}$

$\begin{array}{lll}-1.073652 & 0.133422 & 0.627930\end{array}$

$\begin{array}{lll}-1.058896 & -0.861014 & 1.672986\end{array}$

$\begin{array}{lll}-0.612735 & -0.498643 & 2.514477\end{array}$

$\begin{array}{lll}-1.721154 & 1.440889 & 1.078604\end{array}$

$\begin{array}{lll}-2.014368 & 1.920473 & 0.104477\end{array}$

$\begin{array}{lll}-1.096557 & 2.012869 & 1.650296\end{array}$

$\begin{array}{lll}-2.019936 & -1.108732 & 1.906448\end{array}$

$\begin{array}{lll}-1.874623 & -0.326979 & -0.400673\end{array}$

$\begin{array}{llll}-2.566370 & 1.234168 & 1.617843\end{array}$

$\begin{array}{lll}-2.133322 & 0.550887 & -0.983989\end{array}$

$\begin{array}{llll}-2.307738 & 1.881124 & -1.334879\end{array}$

$\begin{array}{lll}-3.242105 & 2.076439 & -1.481194\end{array}$

$\begin{array}{lll}-0.815069 & -2.728567 & -1.481079\end{array}$

$\begin{array}{lll}-0.109714 & -2.864991 & -0.823370\end{array}$

$\begin{array}{lll}-1.229005 & -1.891840 & -1.196267\end{array}$

$\begin{array}{lll}0.957754 & -2.710999 & 0.772243\end{array}$

$\begin{array}{llll}1.670246 & -2.105432 & 0.523282\end{array}$

$\begin{array}{llll}0.249123 & -2.130099 & 1.132847\end{array}$

\section{E.xyz}

$\begin{array}{llll}\text { C } & 2.763603 & -0.694866 & -0.784641\end{array}$

$\begin{array}{llll}1.446778 & -0.519224 & -1.204875\end{array}$

$0.421486 \quad-0.351234-0.267006$

$\begin{array}{lll}0.728059 & -0.372269 & 1.093102\end{array}$

$\begin{array}{lll}2.047483 & -0.546488 & 1.514782\end{array}$

$\begin{array}{lll}3.067375 & -0.704980 & 0.577999\end{array}$

$\begin{array}{llll}3.551505 & -0.821832 & -1.520527\end{array}$

$\begin{array}{lll}1.229420 & -0.511119 & -2.271221\end{array}$

$\begin{array}{lll}-0.066539 & -0.241145 & 1.820341\end{array}$

$\begin{array}{lll}2.276142 & -0.555957 & 2.576051\end{array}$

$\begin{array}{lll}4.093779 & -0.837722 & 0.905769\end{array}$

$\begin{array}{llll}-1.025587 & -0.091437 & -0.708085\end{array}$

$\begin{array}{llll}-1.051835 & 1.027640 & -1.634995\end{array}$

$\begin{array}{llll}-0.526376 & 0.841193 & -2.488006\end{array}$

$\begin{array}{llll}-1.451940 & -1.391700 & -1.507557\end{array}$

$\begin{array}{lll}-1.464489 & -2.185199 & -0.856102\end{array}$

$\begin{array}{llll}-0.835647 & -1.610786 & -2.295383\end{array}$

$\begin{array}{llll}-2.019818 & 1.224228 & -1.884921\end{array}$

$\begin{array}{lll}-1.913918 & 0.047047 & 0.270295\end{array}$

$\begin{array}{llll}-2.403870 & -1.250485 & -1.858433\end{array}$

$\begin{array}{lll}-2.006594 & -1.405470 & 1.080326\end{array}$

$\begin{array}{lll}-1.968726 & -2.347350 & 1.404025\end{array}$

$\begin{array}{lll}-2.882346 & -2.658639 & 1.414062\end{array}$

$\begin{array}{lll}-1.404160 & 2.308905 & 1.681095\end{array}$

$\begin{array}{llll}-0.660477 & 2.686124 & 1.181152\end{array}$

$\begin{array}{lll}-1.607212 & 1.472988 & 1.193088\end{array}$

$\begin{array}{lll}0.631187 & 2.917968 & -0.294227\end{array}$

$\begin{array}{lll}1.365286 & 2.353473 & -0.013669\end{array}$

$\begin{array}{llll}\text { H } & 0.033413 & 2.319195 & -0.801836\end{array}$

\section{F.xyz}

$\begin{array}{llll}\text { C } & -2.458327 & -0.715256 & 0.570732\end{array}$

$\begin{array}{llll}\text { C } & -1.154328 & -1.205769 & 0.551450\end{array}$

$\begin{array}{llll}\text { C } & -0.207219 & -0.638505 & -0.308514\end{array}$

$\begin{array}{llll}\text { C } & -0.578760 & 0.411429 & -1.154905\end{array}$

C $\quad \begin{array}{llll}-1.881236 & 0.903260 & -1.129360\end{array}$

$\begin{array}{llll}\text { C } & -2.821090 & 0.343689 & -0.262174\end{array}$

$\begin{array}{llll}H & -3.190363 & -1.161777 & 1.235832\end{array}$

$\begin{array}{llll}H & -0.895471 & -2.038398 & 1.198805\end{array}$

$\begin{array}{lllll}H & 0.160639 & 0.848463 & -1.818328\end{array}$

$\begin{array}{llll}H & -2.160716 & 1.725368 & -1.780305\end{array}$

$\begin{array}{llll}\mathrm{H} & -3.836124 & 0.727876 & -0.239858\end{array}$

$\begin{array}{llll}1.222964 & -1.079160 & -0.334750\end{array}$

$\begin{array}{lll}1.685535 & -1.759424 & 0.721769\end{array}$

$\begin{array}{lll}1.132462 & -1.916449 & 1.552025\end{array}$

$\begin{array}{llll}2.654429 & -2.052218 & 0.723364\end{array}$

$\begin{array}{llll}1.959202 & -0.796641 & -1.298326\end{array}$

$\begin{array}{llll}2.381883 & 1.952807 & -0.160066\end{array}$

$\begin{array}{llll}1.672472 & 1.836926 & 0.499859\end{array}$

$\begin{array}{llll}2.335803 & 1.162896 & -0.720430\end{array}$

$\begin{array}{llll}0.357243 & 1.675002 & 1.856493\end{array}$

$\begin{array}{lll}-0.467790 & 1.649572 & 1.349677\end{array}$

$\begin{array}{llll}H & 0.477249 & 0.766242 & 2.167293\end{array}$ 
$\begin{array}{llll}C & -3.054113 & 0.960367 & 0.119368\end{array}$ $\begin{array}{llll}-1.711209 & 1.187701 & -0.176619\end{array}$ $\begin{array}{llll}-0.822101 & 0.111314 & -0.271206\end{array}$ $\begin{array}{llll}-1.287403 & -1.190979 & -0.056258\end{array}$ $\begin{array}{llll}-2.627282 & -1.413188 & 0.251968\end{array}$ $\begin{array}{lll}-3.513215 & -0.338402 & 0.337497\end{array}$ $\begin{array}{llll}-3.740995 & 1.798733 & 0.176943\end{array}$ $\begin{array}{lll}-1.368948 & 2.202759 & -0.358140\end{array}$ $\begin{array}{llll}-0.597241 & -2.028212 & -0.112013\end{array}$ $\begin{array}{llll}-2.978211 & -2.424748 & 0.429496\end{array}$ $\begin{array}{lll}-4.558215 & -0.512756 & 0.574000\end{array}$ $\begin{array}{llll}0.613624 & 0.330164 & -0.619752\end{array}$ $\begin{array}{llll}1.295921 & -0.442385 & -1.392933\end{array}$ $\begin{array}{llll}1.226756 & 1.397179 & -0.014963\end{array}$ $\begin{array}{llll}2.078714 & 1.732388 & -0.451549\end{array}$ $0.715426 \quad-1.197748 \quad-1.751186$ $\begin{array}{lll}0.648887 & 2.109165 & 0.411127\end{array}$ $\begin{array}{llll}2.182659 & 0.371815 & 1.511767\end{array}$ $\begin{array}{lll}4.008844 & -0.459885 & -0.678917\end{array}$ $\begin{array}{llll}3.838596 & -0.423230 & 0.277736\end{array}$ $3.099945-0.469802-1.063342$ $\begin{array}{lll}2.771672 & -0.279261 & 1.932905\end{array}$ $\begin{array}{lll}3.186720 & 0.189398 & 2.668537\end{array}$

\section{H.xyz}

$\begin{array}{llll}\text { C } & 2.853501 & 0.456570 & -0.842684\end{array}$ $\begin{array}{llll}1.526479 & 0.795243 & -1.101218\end{array}$ $\begin{array}{llll}0.580313 & 0.762023 & -0.070918\end{array}$ $\begin{array}{llll}0.974084 & 0.380371 & 1.217287\end{array}$ $\begin{array}{llll}2.299818 & 0.034247 & 1.470990\end{array}$ $\begin{array}{lll}3.241472 & 0.070869 & 0.440673\end{array}$ $\begin{array}{llll}3.583507 & 0.494109 & -1.644860\end{array}$ $\begin{array}{llll}1.240928 & 1.104164 & -2.102940\end{array}$ $\begin{array}{llll}0.239502 & 0.327593 & 2.016153\end{array}$ $\begin{array}{lll}2.594086 & -0.274192 & 2.469029\end{array}$ $\begin{array}{lll}4.273629 & -0.201002 & 0.637927\end{array}$ $\begin{array}{llll}-0.850258 & 1.111341 & -0.319919\end{array}$ $\begin{array}{lll}-1.602849 & 1.736143 & 0.517821\end{array}$ $\begin{array}{llll}-1.388068 & 0.641779 & -1.492758\end{array}$ $\begin{array}{llll}-2.254841 & 1.076980 & -1.788534\end{array}$ $\begin{array}{lll}-1.073937 & 1.995699 & 1.348242\end{array}$ $\begin{array}{llll}0.788603 & -2.686381 & -0.299452\end{array}$ $\begin{array}{lll}-0.760014 & 0.382490 & -2.242499\end{array}$ $\begin{array}{lll}1.375066 & -2.041223 & 0.118752\end{array}$ $\begin{array}{llll}-1.869856 & -1.182996 & -0.746829\end{array}$ $\begin{array}{llll}-3.957204 & 0.155530 & 0.763654\end{array}$ $\begin{array}{llll}-3.475534 & -0.676553 & 0.628579\end{array}$ $\begin{array}{rrrr}H & -3.252960 & 0.835727 & 0.691315\end{array}$

$\begin{array}{lllll}\text { O } & -1.947471 & -1.866336 & -0.053906\end{array}$ $\begin{array}{llll}-2.392311 & -2.615255 & -0.474367\end{array}$ $\begin{array}{llll}-0.114728 & -2.357483 & -0.133052\end{array}$

\section{H_I_TS.xyz}

$\begin{array}{llll}\text { C } & 3.155399 & -1.036974 & -0.507634\end{array}$ $\begin{array}{llll}\text { C } & 1.764267 & -1.034564 & -0.629492\end{array}$ $\begin{array}{llll}\text { C } & 1.023211 & 0.054636 & -0.165167\end{array}$ C $\quad 1.687004 \quad 1.138254 \quad 0.422883$ $\begin{array}{llll}\text { C } & 3.071958 & 1.129856 & 0.547341\end{array}$ $\begin{array}{llll}\text { C } & 3.811966 & 0.040457 & 0.081015\end{array}$ $\begin{array}{llll}H & 3.721335 & -1.886202 & -0.877179\end{array}$ H $\quad 1.283502 \quad-1.886548$ - 1.101340 $\begin{array}{llll}H & 1.115735 & 1.982977 & 0.798968\end{array}$ $\begin{array}{llll}H & 3.574427 & 1.972026 & 1.012460\end{array}$ $\begin{array}{llll}H & 4.892978 & 0.034014 & 0.177995\end{array}$ C $\quad-0.463533 \quad 0.130258 \quad-0.318369$ $\begin{array}{llll}N & -1.103395 & 1.167151 & -0.740936\end{array}$ $\begin{array}{llll}N & -1.119760 & -1.148742 & -0.704321\end{array}$ $\begin{array}{llll}H & -0.990311 & -1.338252 & -1.704445\end{array}$ $\begin{array}{llll}H & -0.527678 & 2.003312 & -0.668516\end{array}$ \begin{tabular}{lllll}
\hline & -0.905392 & -0.318636 & 1.547600
\end{tabular} H $\quad-0.763113 \quad-1.936237 \quad-0.154792$ $\begin{array}{llll}H & -0.701694 & 0.520140 & 1.982864\end{array}$

H $\quad-2.128556 \quad-1.064195 \quad-0.502039$

$\begin{array}{lllll}\mathrm{O} & -3.873057 & 0.953730 & -1.087384\end{array}$

H $\quad-4.009527 \quad 0.355532 \quad-0.332635$

$\begin{array}{llll}H & -2.900767 & 1.125134 & -1.042741\end{array}$

$\begin{array}{llll}\text { O } & -3.380469 & -0.695283 & 1.160213\end{array}$

H $\quad-3.629592 \quad-1.543051 \quad 1.548749$

H $\quad-2.404934 \quad-0.517533 \quad 1.432555$ 


\section{I.xyz}

$\begin{array}{llll}-3.130300 & 1.056204 & 0.508888\end{array}$ $\begin{array}{llll}-1.742149 & 1.109959 & 0.413633\end{array}$ $\begin{array}{llll}-1.023221 & 0.020819 & -0.094776\end{array}$

$\begin{array}{llll}-1.711802 & -1.122644 & -0.500801\end{array}$

$\begin{array}{llll}-3.104764 & -1.173691 & -0.409895\end{array}$ $\begin{array}{lll}-3.816654 & -0.087632 & 0.094873\end{array}$

$\begin{array}{llll}-3.676377 & 1.906670 & 0.905237\end{array}$

$\begin{array}{lll}-1.216793 & 2.007928 & 0.733529\end{array}$

$\begin{array}{lll}-1.161590 & -1.970785 & -0.893017\end{array}$

$\begin{array}{llll}-3.631031 & -2.066421 & -0.733964\end{array}$

$\begin{array}{lll}-4.899037 & -0.129484 & 0.166764\end{array}$

$0.490596 \quad 0.120620-0.233291$

$\begin{array}{llll}0.993197 & 1.139513 & -0.986272\end{array}$

$\begin{array}{lll}1.009798 & 0.202718 & 1.314827\end{array}$

$\begin{array}{llll}0.649188 & 1.051800 & 1.754157\end{array}$

$\begin{array}{llll}0.337436 & 1.915600 & -1.001966\end{array}$

$\begin{array}{llll}1.065201 & -1.125756 & -0.584251\end{array}$

$\begin{array}{lll}0.722453 & -0.607331 & 1.870992\end{array}$

$\begin{array}{lll}1.450573 & -0.984251 & -1.462949\end{array}$

$\begin{array}{llll}2.033961 & 0.243992 & 1.297294\end{array}$

$\begin{array}{llll}3.627721 & 1.323762 & -0.654645\end{array}$

$\begin{array}{llll}3.833953 & 0.520575 & -0.152586\end{array}$

$\begin{array}{lll}2.613745 & 1.290358 & -0.796080\end{array}$

$\begin{array}{lll}3.639738 & -1.293185 & 0.685935\end{array}$

$\begin{array}{llll}3.696678 & -1.819102 & 1.494207\end{array}$

$\begin{array}{lll}2.794352 & -1.535553 & 0.270415\end{array}$

\section{J.xyz}

$\begin{array}{llll}\text { C } & 2.175981 & -1.065943 & 0.560703\end{array}$ $\begin{array}{llll}0.814590 & -1.307867 & 0.730365\end{array}$ $\begin{array}{lll}-0.110532 & -0.774685 & -0.174863\end{array}$

$\begin{array}{llll}0.339541 & 0.006617 & -1.245947\end{array}$

$\begin{array}{llll}1.702839 & 0.238591 & -1.417478\end{array}$

$2.622434 \quad-0.294576-0.514653$

$\begin{array}{llll}2.886671 & -1.473354 & 1.272346\end{array}$

$0.478364 \quad-1.892269 \quad 1.581815$

$\begin{array}{lll}-0.374379 & 0.426129 & -1.947031\end{array}$

$\begin{array}{llll}2.044871 & 0.839595 & -2.253885\end{array}$

$\begin{array}{lll}3.683681 & -0.106545 & -0.643712\end{array}$

$\begin{array}{llll}-1.563714 & -1.036243 & 0.003203\end{array}$

$\begin{array}{lll}-2.123833 & -1.990813 & 0.635269\end{array}$

$\begin{array}{lll}-1.427661 & -2.628148 & 1.018982\end{array}$

$\begin{array}{llll}-2.331761 & -0.103809 & -0.614230\end{array}$

$\begin{array}{lll}-3.266445 & -0.339582 & -0.489879\end{array}$

$\begin{array}{lll}0.829735 & 2.088596 & 1.613602\end{array}$

$\begin{array}{lll}0.055040 & 2.179571 & 1.023862\end{array}$

$\begin{array}{lll}1.197444 & 1.214649 & 1.424129\end{array}$

$\begin{array}{lll}-1.424193 & 2.574255 & -0.000819\end{array}$

$\begin{array}{lllll}H & -1.063190 & 2.925844 & -0.825764\end{array}$

$\begin{array}{llll}H & -1.824651 & 1.722106 & -0.244154\end{array}$

\section{J_K_TS.xyz}

C $\quad 2.378270 \quad 0.843338 \quad-0.566421$

$\begin{array}{llll}\text { C } & 1.050664 & 1.254275 & -0.643553\end{array}$

$\begin{array}{llll}\text { C } & 0.107128 & 0.716679 & 0.240898\end{array}$

$\begin{array}{lll}0.494311 & -0.222752 & 1.203452\end{array}$

$\begin{array}{lll}1.825248 & -0.624073 & 1.280070\end{array}$

$\begin{array}{llll}2.764201 & -0.095787 & 0.393371\end{array}$

$\begin{array}{llll}3.110074 & 1.250930 & -1.255893\end{array}$

$\begin{array}{llll}0.748873 & 1.976112 & -1.396819\end{array}$

$\begin{array}{lll}-0.246843 & -0.633959 & 1.881652\end{array}$

$\begin{array}{llll}2.128170 & -1.351470 & 2.025900\end{array}$

$\begin{array}{lll}3.799974 & -0.415832 & 0.448651\end{array}$

$\begin{array}{llll}-1.306591 & 1.099229 & 0.141461\end{array}$

$\begin{array}{llll}-1.897757 & 2.010490 & -0.567792\end{array}$

$\begin{array}{llll}-1.426784 & 2.672560 & -1.175989\end{array}$

$\begin{array}{lll}-2.255654 & 0.487779 & 0.818470\end{array}$

$\begin{array}{lll}-2.842176 & 1.397695 & 0.114195\end{array}$

$0.149357-1.952203-1.815211$

$\begin{array}{llll}-0.549664 & -1.989827 & -1.131880\end{array}$

$\begin{array}{llll}0.689797 & -1.184097 & -1.586053\end{array}$

$\begin{array}{llll}-1.934119 & -2.233741 & 0.064522\end{array}$

$\begin{array}{lll}-1.535176 & -2.693750 & 0.815219\end{array}$

H $\quad-2.148019 \quad-1.341926 \quad 0.397635$ 
$\begin{array}{llll}\text { C } & 2.059400 & -1.225236 & 0.578131\end{array}$ $\begin{array}{llll}0.676763 & -1.356891 & 0.704783\end{array}$ $\begin{array}{lll}-0.168718 & -0.713837 & -0.205915\end{array}$ $\begin{array}{llll}0.374013 & 0.054559 & -1.241191\end{array}$ $\begin{array}{llll}1.755233 & 0.169005 & -1.374574\end{array}$ $\begin{array}{llll}2.598883 & -0.467185 & -0.462437\end{array}$ $\begin{array}{llll}2.713399 & -1.710295 & 1.295477\end{array}$ $0.268730 \quad-1.933158 \quad 1.530190$ $\begin{array}{llll}-0.290193 & 0.551905 & -1.941726\end{array}$ $\begin{array}{llll}2.172798 & 0.757435 & -2.185167\end{array}$ $\begin{array}{lll}3.675621 & -0.369113 & -0.559039\end{array}$ $\begin{array}{llll}-1.657425 & -0.789313 & -0.089865\end{array}$ $\begin{array}{lll}-2.182299 & -1.908921 & 0.416623\end{array}$ $\begin{array}{lll}-1.611893 & -2.710578 & 0.647360\end{array}$ $\begin{array}{llll}-2.374690 & 0.161594 & -0.458468\end{array}$ $-3.186468 \quad-1.976500 \quad 0.525950$ $\begin{array}{lll}0.913127 & 2.014973 & 1.661779\end{array}$ $\begin{array}{lll}0.184601 & 2.179346 & 1.029545\end{array}$ $\begin{array}{lll}1.212571 & 1.113409 & 1.481769\end{array}$ $\begin{array}{llll}-1.199508 & 2.659677 & -0.078933\end{array}$ $\begin{array}{lll}-0.775871 & 2.939890 & -0.901128\end{array}$ $\begin{array}{llll}-1.627527 & 1.803538 & -0.288214\end{array}$

\section{L.xyz}

$\begin{array}{llll}\text { C } & -2.556150 & -1.347929 & 0.310428\end{array}$

$\begin{array}{llll}-1.816193 & -0.171658 & 0.421915\end{array}$

$\begin{array}{llll}-0.452185 & -0.164965 & 0.105601\end{array}$

$\begin{array}{llll}0.161408 & -1.349852 & -0.316682\end{array}$

$\begin{array}{llll}-0.579258 & -2.523649 & -0.423228\end{array}$

$\begin{array}{llll}-1.939635 & -2.525579 & -0.110267\end{array}$

$\begin{array}{llll}-3.614801 & -1.340822 & 0.549423\end{array}$

$\begin{array}{lll}-2.312084 & 0.741835 & 0.737248\end{array}$

$\begin{array}{llll}1.220097 & -1.352351 & -0.554687\end{array}$

$\begin{array}{llll}-0.092426 & -3.438793 & -0.745066\end{array}$

$\begin{array}{llll}-2.516009 & -3.441704 & -0.193851\end{array}$

$\begin{array}{llll}0.350770 & 1.088145 & 0.206719\end{array}$

$\begin{array}{llll}1.381904 & 1.260070 & -0.546680\end{array}$

$\begin{array}{lll}-0.130755 & 2.034495 & 1.080702\end{array}$

$\begin{array}{lll}-0.661824 & 1.700369 & 1.876547\end{array}$

$\begin{array}{lll}0.498377 & 2.801320 & 1.293725\end{array}$

$\begin{array}{llll}1.834319 & 2.151994 & -0.337181\end{array}$

$\begin{array}{lll}2.851227 & -0.497699 & 1.919495\end{array}$

$\begin{array}{lll}2.513939 & -0.148316 & 1.085177\end{array}$

$\begin{array}{llll}-2.117289 & 3.045482 & -0.975559\end{array}$

$\begin{array}{lll}-1.534711 & 2.836464 & -0.225204\end{array}$

$\begin{array}{llll}-2.300352 & 2.188023 & -1.381990\end{array}$

$\begin{array}{llll}3.381399 & -0.421697 & -1.564996\end{array}$

$\begin{array}{lll}3.647859 & -0.926802 & -0.784973\end{array}$

$\begin{array}{llll}2.624326 & 0.131063 & -1.255750\end{array}$

\section{L_M_TS.xyz}

$\begin{array}{llll}\text { C } & -2.756650 & -0.206458 & 0.460343\end{array}$

$\begin{array}{llll}\text { C } & -1.548105 & 0.487679 & 0.551292\end{array}$

$\begin{array}{llll}\text { C } & -0.356172 & -0.096644 & 0.111132\end{array}$

C $\quad-0.400110 \quad-1.389345-0.426893$

$\begin{array}{llll}\text { C } & -1.603951 & -2.082930 & -0.513802\end{array}$

$\begin{array}{llll}\text { C } & -2.790331 & -1.494298 & -0.069521\end{array}$

$\begin{array}{llll}H & -3.671647 & 0.266091 & 0.804651\end{array}$

H $\quad-1.551305 \quad 1.491888 \quad 0.963213$

$\begin{array}{llll}\text { H } & 0.517430 & -1.854713 & -0.772574\end{array}$

$\begin{array}{llll}H & -1.616593 & -3.086172 & -0.929306\end{array}$

H $\quad-3.729429 \quad-2.034579 \quad-0.138749$

$\begin{array}{llll}\text { C } & 0.960205 & 0.633964 & 0.190821\end{array}$

$\begin{array}{lllll}N & 1.850028 & 0.376350 & -0.749524\end{array}$

$\begin{array}{llll}\mathrm{N} & 0.871383 & 1.947801 & 0.722033\end{array}$

H $\quad 0.441894 \quad 1.949239 \quad 1.643456$

$\begin{array}{llll}\mathrm{H} & 1.802067 & 2.349307 & 0.805283\end{array}$

H $\quad 2.614880 \quad 1.049313 \quad-0.682389$

$\begin{array}{llll}\text { O } & 1.518287 & -0.229280 & 1.862390\end{array}$

H $\quad \begin{array}{lll}1.584913 & -1.157228 & 1.597549\end{array}$

$\begin{array}{lllll}\text { O } & -0.648572 & 3.218685 & -1.311007\end{array}$

H $\quad-0.121112 \quad 2.828501 \quad-0.574219$

$\begin{array}{llll}\mathrm{H} & -1.270558 & 2.522875 & -1.560347\end{array}$

$\begin{array}{lllll}\text { O } & 3.047412 & -2.019383 & -0.812158\end{array}$

$\begin{array}{llll}H & 3.033849 & -2.328448 & 0.102577\end{array}$

H $\quad 2.549390 \quad-1.137112 \quad-0.800751$ 


\section{M.xyz}

$\begin{array}{llll}C & -2.478368 & -0.665281 & 0.856130\end{array}$ $\begin{array}{llll}-1.119471 & -0.965979 & 0.904932\end{array}$ $\begin{array}{llll}-0.264944 & -0.578537 & -0.134642\end{array}$ $\begin{array}{llll}-0.797444 & 0.100916 & -1.231882\end{array}$ $\begin{array}{llll}-2.160934 & 0.402095 & -1.281247\end{array}$ $\begin{array}{llll}-3.003883 & 0.025414 & -0.238277\end{array}$ $\begin{array}{lll}-3.126603 & -0.967283 & 1.673107\end{array}$ $\begin{array}{lll}-0.715079 & -1.499487 & 1.760753\end{array}$ $\begin{array}{llll}-0.151303 & 0.408654 & -2.046053\end{array}$ $\begin{array}{llll}-2.559827 & 0.937511 & -2.137548\end{array}$ $\begin{array}{llll}-4.062103 & 0.264947 & -0.276211\end{array}$ $\begin{array}{llll}1.220278 & -0.921281 & -0.025993\end{array}$ $\begin{array}{lll}1.725826 & -0.417821 & 1.226690\end{array}$ $\begin{array}{llll}1.505153 & -2.349156 & -0.067336\end{array}$ $\begin{array}{llll}1.071555 & -2.742639 & -0.900568\end{array}$ $\begin{array}{lll}1.066394 & -2.792943 & 0.736837\end{array}$ $\begin{array}{lll}2.739725 & -0.511055 & 1.235276\end{array}$ $\begin{array}{lll}1.857364 & -0.346983 & -1.165176\end{array}$ $2.784805 \quad-0.627238 \quad-1.138343$ $\begin{array}{lll}0.177925 & 2.335376 & 1.503405\end{array}$ $\begin{array}{lll}1.476844 & 0.568857 & 1.324305\end{array}$ $\begin{array}{lll}-0.488685 & 1.644117 & 1.392199\end{array}$ $\begin{array}{llll}1.508382 & 2.540798 & -0.611747\end{array}$ $\begin{array}{llll}0.930769 & 2.431949 & 0.260636\end{array}$ $\begin{array}{llll}1.695887 & 1.635830 & -0.905848\end{array}$

\section{M_N_TS.xyz}

$\begin{array}{llll}\text { C } & -2.588202 & -0.622725 & 0.805475\end{array}$

$\begin{array}{llll}\text { C } & -1.242194 & -0.976167 & 0.868184\end{array}$

$\begin{array}{llll}\text { C } & -0.348580 & -0.531638 & -0.112946\end{array}$

C $\quad-0.8183390 .258318-1.161536$

$\begin{array}{llll}\text { C } & -2.167069 & 0.616055 & -1.222455\end{array}$

$\begin{array}{llll}\text { C } & -3.053136 & 0.179451 & -0.239382\end{array}$

$\begin{array}{lll}-3.273892 & -0.971456 & 1.571613\end{array}$

$\begin{array}{lll}-0.882986 & -1.596477 & 1.684707\end{array}$

$\begin{array}{llll}-0.124525 & 0.602009 & -1.921017\end{array}$

$\begin{array}{llll}-2.522123 & 1.238512 & -2.038134\end{array}$

$\begin{array}{llll}-4.101160 & 0.459122 & -0.286020\end{array}$

$\begin{array}{lll}1.128128 & -0.879387 & -0.011554\end{array}$

$\begin{array}{lll}1.637904 & -0.465239 & 1.273446\end{array}$

$\begin{array}{lll}1.369876 & -2.367875 & -0.194219\end{array}$

$\begin{array}{lll}0.543923 & -2.902760 & -0.459519\end{array}$

$\begin{array}{lll}1.845885 & -2.805782 & 0.593623\end{array}$

$\begin{array}{llll}2.656044 & -0.475367 & 1.221375\end{array}$

$\begin{array}{lll}1.890536 & -0.489503 & -1.119728\end{array}$

$\begin{array}{llll}1.999966 & -1.797572 & -1.067383\end{array}$

$\begin{array}{llll}0.375870 & 2.358487 & 1.424800\end{array}$

$\begin{array}{lll}1.343054 & 0.504292 & 1.431807\end{array}$

$\begin{array}{lll}-0.424453 & 1.864891 & 1.199674\end{array}$

$\begin{array}{lll}1.886041 & 2.343411 & -0.603157\end{array}$

$\begin{array}{lll}1.246925 & 2.339603 & 0.219924\end{array}$

$\begin{array}{llll}1.955676 & 1.410176 & -0.875275\end{array}$

\section{N.xyz}

$\begin{array}{llll}\text { C } & -2.463063 & -0.594259 & 0.915565\end{array}$

$\begin{array}{llll}\text { C } & -1.096935 & -0.869358 & 0.944657\end{array}$

C $\quad-0.279301 \quad-0.522492-0.137713$

$\begin{array}{llll}\text { C } & -0.850747 & 0.091708 & -1.251530\end{array}$

C $\quad-2.218605 \quad 0.370203 \quad-1.281929$

$\begin{array}{llll}\text { C } & -3.027203 & 0.031011 & -0.198215\end{array}$

$\begin{array}{llll}\mathrm{H} & -3.085692 & -0.863677 & 1.763309\end{array}$

$\begin{array}{llll}H & -0.664397 & -1.345303 & 1.820834\end{array}$

$\begin{array}{llll}H & -0.217427 & 0.364535 & -2.089012\end{array}$

$\begin{array}{llll}H & -2.650060 & 0.856548 & -2.151638\end{array}$

H $\quad-4.090144 \quad 0.251264 \quad-0.219620$

$\begin{array}{llll}\text { C } & 1.236989 & -0.773421 & -0.102157\end{array}$

N $\quad 1.751039 \quad-0.361645 \quad 1.201326$

$\begin{array}{llll}N & 1.385924 & -2.347208 & -0.059475\end{array}$

H $\quad 1.020610 \quad-2.746371 \quad-0.927386$

$\begin{array}{llll}\mathrm{H} & 0.905772 & -2.770777 & 0.738094\end{array}$

H $\quad 2.760065 \quad-0.259815 \quad 1.096522$

$\begin{array}{lllll}\text { O } & 1.912336 & -0.355650 & -1.163932\end{array}$

$\begin{array}{llll}\text { H } & 2.384191 & -2.565946 & 0.001250\end{array}$

$\begin{array}{lllll}\mathrm{O} & 0.254210 & 2.358174 & 1.452938\end{array}$

H $\quad 1.371734 \quad 0.570344 \quad 1.399700$

H $\quad-0.526262 \quad 1.813135 \quad 1.284485$

$\begin{array}{lllll}\text { O } & 1.611575 & 2.420865 & -0.697910\end{array}$

H $\quad 1.041262 \quad 2.3880690 .166560$

H $\quad 1.759819 \quad 1.482492-0.936890$ 
$\begin{array}{llll}C & -2.817004 & 0.235873 & 0.675017\end{array}$ $\begin{array}{lll}-1.599652 & 0.908562 & 0.609917\end{array}$ $\begin{array}{lll}-0.554947 & 0.416758 & -0.182480\end{array}$ $\begin{array}{lll}-0.754380 & -0.751560 & -0.919882\end{array}$ $\begin{array}{llll}-1.977352 & -1.424139 & -0.856828\end{array}$ $\begin{array}{lll}-3.009372 & -0.936572 & -0.058666\end{array}$ $\begin{array}{lll}-3.616487 & 0.629142 & 1.295292\end{array}$ $\begin{array}{lll}-1.470838 & 1.828925 & 1.176270\end{array}$ $0.037316-1.142973-1.548867$ $\begin{array}{lll}-2.118496 & -2.331920 & -1.435523\end{array}$ $\begin{array}{lll}-3.958181 & -1.461693 & -0.009847\end{array}$ $\begin{array}{lll}0.764084 & 1.187215 & -0.223819\end{array}$ $\begin{array}{llll}0.640428 & 2.537048 & -0.761869\end{array}$ $\begin{array}{lll}0.120036 & 2.496001 & -1.637474\end{array}$ $\begin{array}{lll}1.333411 & 1.219619 & 1.119184\end{array}$ $\begin{array}{lll}0.695364 & 1.700389 & 1.752606\end{array}$ $\begin{array}{lll}2.188697 & 1.775245 & 1.088574\end{array}$ $0.090477 \quad 3.104136-0.118743$ $\begin{array}{llll}1.648104 & 0.488400 & -1.073721\end{array}$ $\begin{array}{llll}2.395372 & 1.076838 & -1.262840\end{array}$ $\begin{array}{lll}1.425562 & -1.478772 & 2.003964\end{array}$ $\begin{array}{lll}1.771745 & -1.932445 & 1.215789\end{array}$ $\begin{array}{lll}1.414989 & -0.529362 & 1.736019\end{array}$ $2.462211-2.177144 \quad-0.576598$ $\begin{array}{lll}1.835610 & -2.728129 & -1.063612\end{array}$ $\begin{array}{llll}2.202252 & -1.257515 & -0.777565\end{array}$

\section{O_P_TS.xyz}

$\begin{array}{llll}C & -2.989790 & 0.185871 & 0.480647\end{array}$

$\begin{array}{llll}-1.793303 & 0.899078 & 0.461713\end{array}$

$\begin{array}{llll}\text { C } & -0.650304 & 0.342322 & -0.121700\end{array}$

$\begin{array}{llll}-0.714069 & -0.930056 & -0.687554\end{array}$

$\begin{array}{llll}-1.912781 & -1.645653 & -0.665730\end{array}$

C $\quad-3.050846 \quad-1.090157 \quad-0.083259$

$\begin{array}{llll}-3.873455 & 0.626121 & 0.932011\end{array}$

$\begin{array}{llll}-1.751073 & 1.894611 & 0.899208\end{array}$

$0.172021-1.361045-1.142209$

$\begin{array}{llll}-1.955123 & -2.636888 & -1.106432\end{array}$

$\begin{array}{llll}-3.982750 & -1.646787 & -0.069553\end{array}$

$\begin{array}{llll}0.659820 & 1.111635 & -0.106063\end{array}$

$\begin{array}{llll}0.518703 & 2.459739 & -0.808227\end{array}$

$\begin{array}{lll}-0.372642 & 2.603002 & -1.281560\end{array}$

$\begin{array}{lll}1.148789 & 1.223821 & 1.247559\end{array}$

$\begin{array}{lll}0.452973 & 1.651902 & 1.855798\end{array}$

$\begin{array}{lll}1.990330 & 1.799138 & 1.257886\end{array}$

$\begin{array}{llll}0.748017 & 3.261777 & -0.222073\end{array}$

$\begin{array}{lll}1.646908 & 0.632458 & -0.964772\end{array}$

$\begin{array}{llll}1.405873 & 1.825815 & -1.396181\end{array}$

$\begin{array}{lll}1.753349 & -1.521820 & 1.863051\end{array}$

$\begin{array}{lll}2.148380 & -1.796458 & 1.015763\end{array}$

$\begin{array}{lll}1.532439 & -0.574863 & 1.719782\end{array}$

$\begin{array}{llll}2.827177 & -1.781755 & -0.774281\end{array}$

$\begin{array}{llll}2.316414 & -2.396933 & -1.316043\end{array}$

$\begin{array}{llll}- & 2.384313 & -0.903605 & -0.882035\end{array}$

\section{P.xyz}

$\begin{array}{llll}\text { C } & -2.691279 & 0.374646 & 0.845068\end{array}$

$\begin{array}{lllll}\text { C } & -1.396309 & 0.886944 & 0.790960\end{array}$

$\begin{array}{llll}\text { C } & -0.476484 & 0.391036 & -0.139824\end{array}$

C $\quad-0.875073 \quad-0.611459-1.023785$

$\begin{array}{llll}\text { C } & -2.171080 & -1.127480 & -0.968744\end{array}$

$\begin{array}{llll}\text { C } & -3.080927 & -0.637766 & -0.033349\end{array}$

H $\quad \begin{array}{llll}-3.395113 & 0.766753 & 1.572671\end{array}$

$\begin{array}{llll}H & -1.116185 & 1.681127 & 1.479255\end{array}$

H $\quad-0.167441 \quad-0.988678 \quad-1.754682$

H $\quad-2.467723 \quad-1.911850-1.658354$

$\begin{array}{llll}\mathrm{H} & -4.088800 & -1.038808 & 0.010608\end{array}$

$\begin{array}{llll}\text { C } & 0.957489 & 0.935869 & -0.220697\end{array}$

$\begin{array}{lllll}N & 0.779170 & 2.412333 & -0.794980\end{array}$

H $\quad 0.370182 \quad 2.358971 \quad-1.731644$

$\begin{array}{llll}\mathrm{N} & 1.522430 & 1.066661 & 1.113276\end{array}$

H $\quad 0.992084 \quad 1.695208 \quad 1.713450$

$\begin{array}{llll}H & 2.471962 & 1.425601 & 1.028404\end{array}$

$\begin{array}{llll}H & 0.188644 & 3.009185 & -0.208453\end{array}$

$\begin{array}{llll}\text { O } & 1.769716 & 0.312278 & -1.057402\end{array}$

H $\quad 1.709430 \quad 2.833648 \quad-0.871238$

$\begin{array}{llll}\text { O } & 1.334246 & -1.653948 & 1.973444\end{array}$

H $\quad \begin{array}{llll}1.561090 & -2.058762 & 1.114985\end{array}$

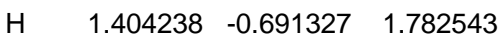

$\begin{array}{lllll}\text { O } & 2.087190 & -2.250736 & -0.692508\end{array}$

H $\quad 1.364261 \quad-2.699555 \quad-1.148987$

H $\quad 1.934939-1.265959-0.842664$ 
$\mathrm{H}_{2}$ O.xyz

$\begin{array}{lll}0.000000 & -0.000000 & 0.117783\end{array}$ $\begin{array}{llll}-0.000000 & 0.765164 & -0.471133\end{array}$

$\begin{array}{llll}H & -0.000000 & -0.765164 & -0.471133\end{array}$

\section{$\mathrm{NH}_{3} . \mathbf{x y z}$}

$\begin{array}{lll}N & 0.000000 \quad 0.000000 & 0.115140\end{array}$

$\begin{array}{llll}\mathrm{H} & 0.000000 & 0.941154 & -0.268659\end{array}$

$\begin{array}{llll}H & 0.815063 & -0.470577 & -0.268659\end{array}$

$\begin{array}{llll}H & -0.815063 & -0.470577 & -0.268659\end{array}$
HO-.xyz

$\begin{array}{llll}\text { O } & 0.000000 & 0.000000 & 0.107155\end{array}$

$\begin{array}{llll}\mathrm{H} & 0.000000 & 0.000000 & -0.857242\end{array}$ 


\section{References}

${ }^{51} \mathrm{H}$. E. Gottlieb, V. Kotlyar, A. Nudelman, NMR chemical shifts of common laboratory solvents as trace impurities, J. Org. Chem. 1997, 62, 7512-7515.

S2 Agilent Technologies, CrysAlisPro, 2011.

S3 L. Palatinus, G. Chapuis, SUPERFLIP - a computer program for the solution of crystal structures by charge flipping in arbitrary dimensions, J. Appl. Crystallogr. 2007, 40, 786-790.

S4 P. W. Betteridge, J. R. Carruthers, R. I. Cooper, K. Prout, D. J. Watkin, CRYSTALS version 12: software for guided crystal structure analysis, J. Appl. Crystallogr. 2003, 36, 1487.

S5 R. I. Cooper, A. L Thompson, D. J. Watkin, CRYSTALS enhancements: dealing with hydrogen atoms in refinement, J. Appl. Crystallogr. 2010, 43, 1100-1107.

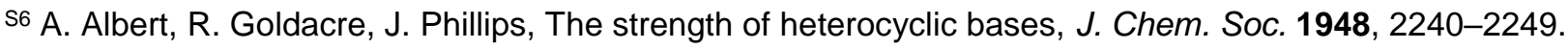

S7 https://www.sigmaaldrich.com/AU/en/product/sial/b6506?context=product, accessed August 2021.

S8 R. E. Cobbledick, R. W. H. Small, The crystal structure of terephthalamide, Acta Cystallogr. 1972, B28, 2893-2896.

s9 S. A. Boer, M. Morshedi, A. Tarzia, C. J. Doonan, N. G. White, Molecular tectonics: a node-and-linker building block approach to a family of hydrogen bonded frameworks, Chem. Eur. J. 2019, 25, 10006-10012.

s10 M. Thomas, T. Anglim Lagones, M. Judd, M. Morshedi, M. L. O'Mara, N. G. White, Hydrogen bond-driven self-assembly between amidiniums and carboxylates: a combined MD, NMR and SCXRD study, Chem. Asian J. 2017, 12, 1587-1597.

s11 J. Nicks, S. A. Boer, N. G. White, J. A. Foster, Monolayer nanosheets formed by liquid exfoliation of charge-assisted hydrogen-bonded frameworks, Chem. Sci. 2021, 12, 3322-3327. 